(Supporting Information)

\title{
Helical Assemblies of One-Dimensional Supramolecular Polymers Composed of Helical Macromolecules: Generation of Circularly Polarized Light Using an Infinitesimal Chiral Source
}

Tomoyuki Ikai, ${ }^{1,2, *}$ Mitsuhiro Okubo, ${ }^{1}$ and Yuya Wada ${ }^{1}$

${ }^{I}$ Graduate School of Natural Science and Technology, Kanazawa University, Kakuma-machi, Kanazawa 920-1192, Japan, 'Department of Molecular and Macromolecular Chemistry, Graduate School of Engineering, Nagoya University, Chikusa-ku, Nagoya 464-8603, Japan

*To whom correspondence should be addressed. E-mail: ikai@chembio.nagoya-u.ac.jp

\section{Table of content:}

1. Materials and method

1.1. Materials

1.2. Instruments

2. Synthetic procedures

2.1. Synthesis of isocyanide monomers and an achiral fluorescent dye

2.2. Homopolymerization of a glycine-based isocyanide

2.3. Dissociation of 1-D supramolecular structures into macromolecular building blocks

2.4. Copolymerization of achiral and chiral isocyanide monomers

\section{Supporting experimental data}

3.1. High-resolution AFM study

3.2. Length evaluation of supra-poly(3) by high-resolution AFM imaging

3.3. Influence of supra-poly $\left(\mathbf{3}_{1-r-c o-2} \mathbf{L}_{r}\right)$ concentration in chloroform on chiroptical properties

3.4. Mixing study using the individually prepared supra-poly $\left(\mathbf{3}_{0.99}-c o-2 \mathbf{L}_{0.01}\right)$ and supra-poly(3) 


\section{Materials and method}

\subsection{Materials}

Anhydrous solvents (dichloromethane, chloroform, dimethyl sulfoxide (DMSO), toluene, $N, N$-dimethylformamide (DMF), ethanol, and tetrahydrofuran (THF)), common organic solvents, triethylamine, potassium carbonate, and 1-hydroxybenzotriazole ( $\mathrm{HOBt})$ were purchased from Kanto Kagaku (Tokyo, Japan). Nickel(II) perchlorate hexahydrate $\left(\mathrm{Ni}\left(\mathrm{ClO}_{4}\right)_{2} \cdot 6 \mathrm{H}_{2} \mathrm{O}\right)$, 1-ethyl-3-(3-dimethylaminopropyl)carbodiimide hydrochloride (EDC-HCl), hydrazine monohydrate, 1,2-diiodoethane, and $n$-butyllithium (1.6 M in $n$-hexane) were purchased from Wako Pure Chemical Industries (Osaka, Japan). Tetrakis(triphenylphosphine)palladium(0) $\left(\mathrm{Pd}\left(\mathrm{PPh}_{3}\right)_{4}\right)$ was purchased from Nacalai (Kyoto, Japan). Diphosgene, N,N-dimethyl-4-aminopyridine (DMAP), tributyltin chloride, 2-propyl-1-pentanol, trimethylamine hydrochloride, and tetrabutylammonium bromide were from Sigma-Aldrich (St. Louis, MO, USA). $p$-Toluenesulfonyl chloride and $N$-methylmorpholine were from Kishida (Osaka, Japan). N-Formyl-D-alanine was from Watanabe Chemical Industries (Hiroshima, Japan). $N$-Formylglycine, $N$-formyl-L-alanine, and 2,6-dihydroxyanthracene were from Tokyo Kasei Kogyo (TCI, Tokyo, Japan). 4,8-Bishexyloxybenzo[1,2-b:4,5-b']dithiophene, ${ }^{\mathrm{S} 1}$ tributyl(5-hexylthiophen-2-yl)stannane, ${ }^{\mathrm{S} 2} \mathrm{Th}_{\mathrm{Br}},{ }^{\mathrm{S} 3} \mathrm{TPE},{ }^{\mathrm{S} 4}$ and $\mathrm{Cy}^{3}{ }^{\mathrm{S} 5}$ were prepared according to literature procedures. CHIRALPAK IA $(25 \mathrm{~cm} \times 2.0 \mathrm{~cm}$ (i.d.) $)$ and CHIRALPAK IE-3 $(25 \mathrm{~cm} \times 0.46$ cm (i.d.)) were purchased from Daicel (Tokyo, Japan).

\subsection{Instruments}

NMR spectra were recorded on a JNM-ECA 500 (JEOL, Tokyo, Japan) (500 MHz for ${ }^{1} \mathrm{H}, 126 \mathrm{MHz}$ for ${ }^{13} \mathrm{C}$ ) spectrometer in $\mathrm{CDCl}_{3}$ using tetramethylsilane as the internal standard. Melting points were measured on a Yanako (Kyoto, Japan) melting point apparatus and were uncorrected. Microwave irradiation experiments were performed using an EYELA Wave Magic MWO-1000S (Tokyo Rikakikai, Tokyo, Japan). IR spectra were obtained using a JASCO (Hachioji, Japan) Fourier Transform IR-4700 spectrophotometer. The optical rotation was measured at $25^{\circ} \mathrm{C}$ with a JASCO P-1030 polarimeter. The molecular masses of the polymerization products were estimated using size-exclusion chromatography (SEC) equipped with TSKgel $\alpha-M$ column (Tosoh, Tokyo, Japan), a JASCO PU-2080 Plus HPLC pump, and a JASCO UV-970 UV/VIS detector at 254 or $300 \mathrm{~nm}$, where THF containing $0.25 \mathrm{wt} \%$ 
tetrabutylammonium bromide was used as the eluent. The molecular mass calibration curve was obtained with linear polystyrene standards (Tosoh). Absorption and circular dichroism (CD) spectra were measured in chloroform using JASCO V-570 (a scanning rate of $200 \mathrm{~nm} \mathrm{~min} \mathrm{~m}^{-1}$ and a bandwidth

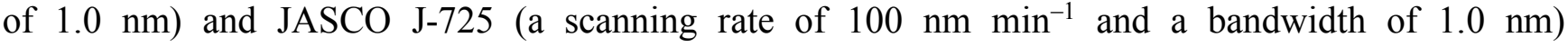
spectrometers, respectively, with a 0.10-, 1.0-, or 10-mm path length quartz cell (UV-grade) (GL Sciences, Tokyo, Japan). The temperature was controlled using a JASCO ETC-505T (absorption spectroscopy) and a JASCO PTC-348WI apparatus (CD spectroscopy). The X-ray diffraction (XRD) patterns in the film state were recorded using an X-ray diffractometer SmartLab (Rigaku, Tokyo, Japan) with an X-ray tube $(\mathrm{Cu} \mathrm{K \alpha}$ radiation, $\lambda=1.540 \AA)$. The feed ratios of an achiral monomer (3) and chiral monomer (2L or 2D) were determined using HPLC equipped with CHIRALPAK IE-3 column (25 cm $\times 0.46 \mathrm{~cm}$ (i.d.), a JASCO PU-2080 Intelligent HPLC pump and a JASCO MD-2018 multi-wavelength UV/VIS detector (eluent, hexane/ethyl acetate (80:20, v/v); flow rate, $0.5 \mathrm{~mL} \mathrm{~min}^{-1}$; temperature, $c a .20^{\circ} \mathrm{C}$ ). Analyte solutions were injected into the chromatographic system by a Rheodyne Model 7125 injector (Rheodyne, Rohnert Park, CA, USA). The chromatographic purification of enantiomers using CHIRALPAK IA column $(25 \mathrm{~cm} \times 2.0 \mathrm{~cm}$ (i.d.) was also performed using the same HPLC system additionally equipped with a JASCO CD-2095 CD detector (eluent, hexane/dichloromethane $(55: 45, \mathrm{v} / \mathrm{v})$; flow rate, $10 \mathrm{~mL} \mathrm{~min}^{-1}$; temperature, ca. $\left.20{ }^{\circ} \mathrm{C}\right)$. Photoluminescence (PL) and circularly polarized luminescence (CPL) spectra in solution states were recorded at room temperature on a JASCO CPL-300 with 10-mm path length quartz cell (GL Sciences, UV-grade). A drop-coated films prepared on a quartz substrate (Daico MFG, USQ-grade) from a chloroform solution of the polymers ( $\left.c a .23 \mathrm{mg} \mathrm{mL}^{-1}\right)$ was used for solid-state spectral measurements. A scanning rate of $100 \mathrm{~nm} \mathrm{~min}{ }^{-1}$, an excitation slit width of $3000 \mu \mathrm{m}$, a monitoring slit width of 3000 $\mu \mathrm{m}$, a response time of 4 seconds and 2 times (solution state) or single (film state) accumulation were employed. For high-resolution atomic force microscope (AFM) imaging, see Section 3.1 in the Supporting Information (SI). Elemental analyses were performed by the Research Institute for Instrumental Analysis of Advanced Science Research Center, Kanazawa University, Kanazawa, Japan. High-resolution mass spectra (HRMS) were recorded on a JEOL JMS-700 spectrometer with fast atom bombardment (FAB) as the ionization technique. 


\section{Synthetic procedures}

2.1. Synthesis of isocyanide monomers and an achiral fluorescent dye

Achiral glycine-based (3) and chiral alanine-based (2L and 2D) isocyanides and the achiral anthracene derivative (ANT) were prepared according to Scheme S1.
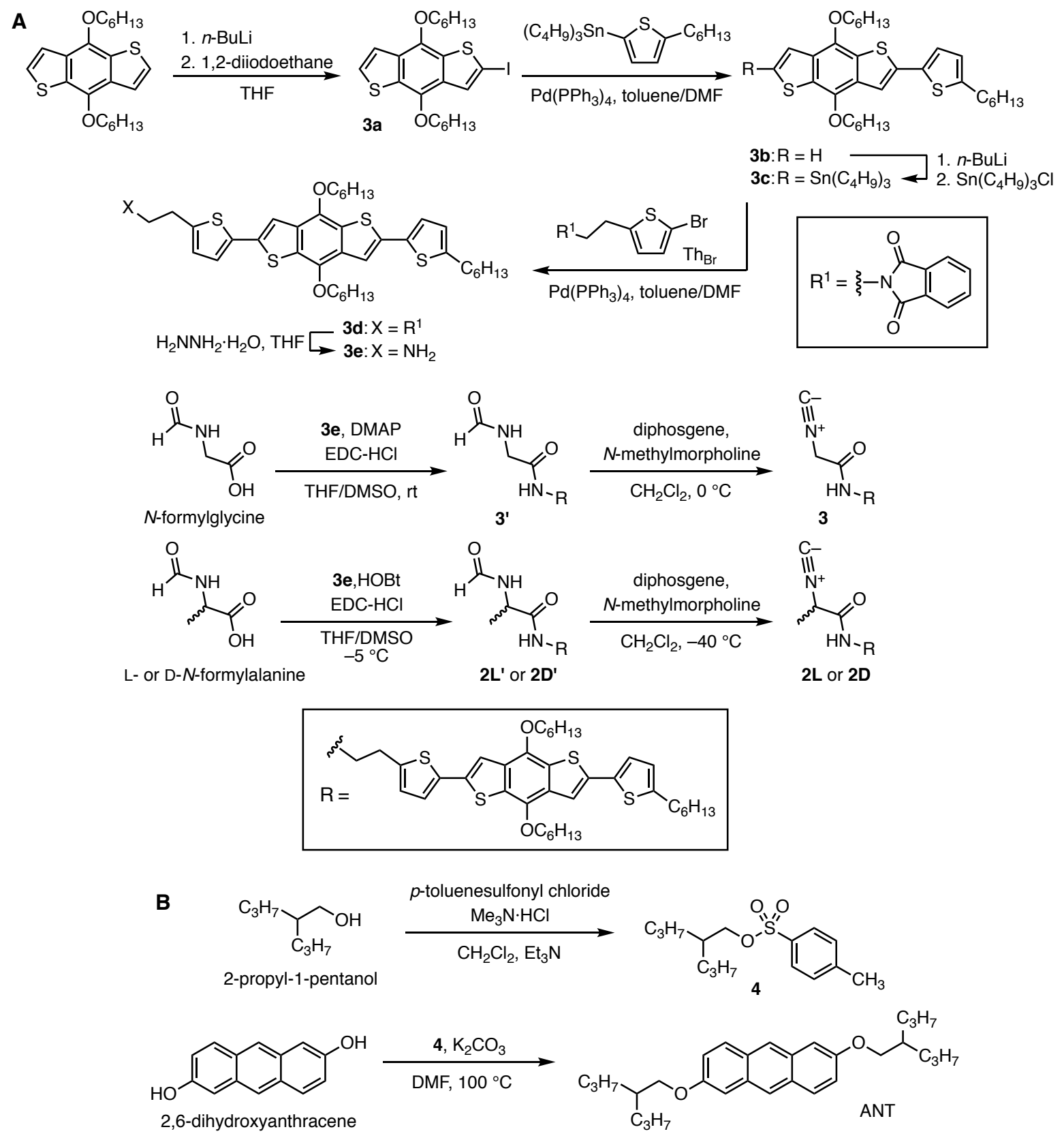

Scheme S1 Synthesis of isocyanide monomers (3, 2L, and 2D) (A) and ANT (B). 
3a. To a solution of 4,8-bishexyloxybenzo[1,2-b:4,5- $\left.b^{\prime}\right]$ dithiophene (810 $\left.\mathrm{mg}, 2.07 \mathrm{mmol}\right)$ in anhydrous THF (7.4 mL) was added dropwise $n$-butyllithium (1.6 M in hexane, $1.29 \mathrm{~mL}, 2.07 \mathrm{mmol})$ via syringe at $-78^{\circ} \mathrm{C}$ under a dry nitrogen atmosphere. After the mixture was stirred at $-78^{\circ} \mathrm{C}$ for $1 \mathrm{~h}$, 1,2-diiodoethane $(0.70 \mathrm{~g}, 2.5 \mathrm{mmol})$ was added. The reaction system was warmed to room temperature and stirred for $12 \mathrm{~h}$. The mixture was diluted with dichloromethane and the solution was washed with sodium thiosulfate aqueous solution and water, and then dried over $\mathrm{Na}_{2} \mathrm{SO}_{4}$. The solvent was removed under reduced pressure and the crude product was purified by silica gel chromatography using hexanedichloromethane $(4: 1, \mathrm{v} / \mathrm{v})$ as the eluent to give the desired product as a yellow oil $(0.95 \mathrm{~g}, 89 \%$ yield $)$. ${ }^{1} \mathrm{H}$ NMR (500 MHz, $\left.\mathrm{CDCl}_{3}, \mathrm{rt}\right): \delta 7.66(\mathrm{~s}, 1 \mathrm{H}, \mathrm{ArH}), 7.44$ (d, J=5.2 Hz, 1H, ArH), 7.40 (d, J=5.7 Hz, $1 \mathrm{H}, \mathrm{ArH}), 4.24\left(\mathrm{q}, J=6.7 \mathrm{~Hz}, 4 \mathrm{H}, \mathrm{OCH}_{2}\right), 1.82-1.89\left(\mathrm{~m}, 4 \mathrm{H}, \mathrm{CH}_{2}\right), 1.52-1.59\left(\mathrm{~m}, 4 \mathrm{H}, \mathrm{CH}_{2}\right), 1.35-1.40$ $\left(\mathrm{m}, 8 \mathrm{H}, \mathrm{CH}_{2}\right), 0.93\left(\mathrm{~m}, 6 \mathrm{H}, \mathrm{CH}_{3}\right)$.

3b. To a solution of 3a (2.08 g, $4.02 \mathrm{mmol})$ and tributyl(5-hexylthiophen-2-yl)stannane (2.76 g, 6.03 $\mathrm{mmol})$ in anhydrous toluene-DMF $(4: 1, \mathrm{v} / \mathrm{v})(10 \mathrm{~mL})$ was added $\mathrm{Pd}\left(\mathrm{PPh}_{3}\right)_{4}(186 \mathrm{mg}, 0.16 \mathrm{mmol})$. The solution was stirred at $120{ }^{\circ} \mathrm{C}$ for $12 \mathrm{~h}$ under microwave heating. After cooling to room temperature, the reaction mixture was diluted with dichloromethane and passed through a short pad of silica gel to remove insoluble materials. After removing the solvent by evaporation, the crude product was purified by silica gel chromatography using hexane-dichloromethane $(5: 1, \mathrm{v} / \mathrm{v})$ as the eluent to give the desired product as a yellow oil $\left(1.62 \mathrm{~g}, 72 \%\right.$ yield). ${ }^{1} \mathrm{H} \mathrm{NMR}\left(500 \mathrm{MHz}, \mathrm{CDCl}_{3}, \mathrm{rt}\right): \delta 7.45(\mathrm{~d}, J=5.7 \mathrm{~Hz}, 1 \mathrm{H}$, ArH), 7.42 (s, 1H, ArH), 7.34 (d, J=5.2 Hz, 1H, ArH), 7.13 (d, J=3.4 Hz, 1H, ArH), 6.74 (d, $J=3.4$ $\mathrm{Hz}, 1 \mathrm{H}, \mathrm{ArH}), 4.25-4.29\left(\mathrm{~m}, 4 \mathrm{H}, \mathrm{OCH}_{2}\right), 2.83\left(\mathrm{t}, J=7.4 \mathrm{~Hz}, 2 \mathrm{H}, \mathrm{CH}_{2}\right), 1.85-1.91\left(\mathrm{~m}, 4 \mathrm{H}, \mathrm{CH}_{2}\right), 1.71$ (quint, $J=7.6 \mathrm{~Hz}, 2 \mathrm{H}), 1.54-1.60\left(\mathrm{~m}, 4 \mathrm{H}, \mathrm{CH}_{2}\right), 1.31-1.41\left(\mathrm{~m}, 14 \mathrm{H}, \mathrm{CH}_{2}\right), 0.89-0.95\left(\mathrm{~m}, 9 \mathrm{H}, \mathrm{CH}_{3}\right)$.

3c. To a solution of $\mathbf{3 b}(766 \mathrm{mg}, 1.38 \mathrm{mmol})$ in anhydrous THF $(5.0 \mathrm{~mL})$ was added dropwise $n$-butyllithium $(1.6 \mathrm{M}$ in hexane, $1.0 \mathrm{~mL}, 1.6 \mathrm{mmol})$ via syringe at $-78{ }^{\circ} \mathrm{C}$ under a dry nitrogen atmosphere. After the mixture was stirred at $-78^{\circ} \mathrm{C}$ for $1 \mathrm{~h}$, tributyltin chloride $(0.59 \mathrm{~g}, 1.8 \mathrm{mmol})$ was added. The mixture was warmed to room temperature and stirred for $3 \mathrm{~h}$. After quenching the reaction with water, the volatile species were evaporated in vacuo. The residue was diluted with dichloromethane and the solution was washed with water, dried over anhydrous $\mathrm{Na}_{2} \mathrm{SO}_{4}$ and concentrated. Compound 3c (1.26 g) was obtained as a yellow oil and was used for the next step without further purification. 
3d. To a solution of 3c (1.26 g) and $\mathrm{Th}$ Br $(696 \mathrm{mg}, 2.07 \mathrm{mmol})$ in anhydrous toluene-DMF (4:1, v/v) $(7 \mathrm{~mL})$ was added $\mathrm{Pd}\left(\mathrm{PPh}_{3}\right)_{4}(64 \mathrm{mg}, 0.055 \mathrm{mmol})$. The solution was stirred at $120{ }^{\circ} \mathrm{C}$ for $12 \mathrm{~h}$ under microwave heating. After cooling to room temperature, the reaction mixture was diluted with dichloromethane and passed through a short pad of silica gel to remove insoluble materials. After removing the solvent by evaporation, the crude product was purified by silica gel chromatography using hexane-dichloromethane $(1: 1, \mathrm{v} / \mathrm{v})$ as the eluent to give the desired product as a yellow oil (1.09 g, 97\% yield over 2 steps). ${ }^{1} \mathrm{H}$ NMR (500 MHz, $\left.\mathrm{CDCl}_{3}, \mathrm{rt}\right): \delta 7.86(\mathrm{dd}, J=5.2,2.9 \mathrm{~Hz}, 2 \mathrm{H}, \mathrm{ArH}), 7.73$ $(\mathrm{dd}, J=5.7,2.9 \mathrm{~Hz}, 2 \mathrm{H}, \mathrm{ArH}), 7.39$ (d, $J=1.1 \mathrm{~Hz}, 2 \mathrm{H}, \mathrm{ArH}), 7.12(\mathrm{t}, J=3.7 \mathrm{~Hz}, 2 \mathrm{H}, \mathrm{ArH}), 6.84(\mathrm{~d}, J=$ $3.4 \mathrm{~Hz}, 1 \mathrm{H}, \mathrm{ArH}), 6.73$ (d, J=3.4 Hz, 1H, ArH), 4.25 (t, J=6.9 Hz, 4H, OCH 2$), 4.01$ (t, J=7.4 Hz, 2H, $\left.\mathrm{CH}_{2}\right), 3.24\left(\mathrm{t}, J=7.4 \mathrm{~Hz}, 2 \mathrm{H}, \mathrm{CH}_{2}\right), 2.83\left(\mathrm{t}, J=7.7 \mathrm{~Hz}, 2 \mathrm{H}, \mathrm{CH}_{2}\right), 1.85-1.91\left(\mathrm{~m}, 4 \mathrm{H}, \mathrm{CH}_{2}\right), 1.71$ (quint, $\left.J=7.4 \mathrm{~Hz}, 2 \mathrm{H}, \mathrm{CH}_{2}\right), 1.55-1.61\left(\mathrm{~m}, 4 \mathrm{H}, \mathrm{CH}_{2}\right), 1.31-1.43\left(\mathrm{~m}, 14 \mathrm{H}, \mathrm{CH}_{2}\right), 0.89-0.96\left(\mathrm{~m}, 9 \mathrm{H}, \mathrm{CH}_{3}\right)$.

3e. To a solution of $\mathbf{3 d}(1.09 \mathrm{~g}, 1.34 \mathrm{mmol})$ in THF (13 mL) was added hydrazine monohydrate $(0.65 \mathrm{~mL}, 13 \mathrm{mmol})$ under a dry nitrogen atmosphere. After stirring at $75{ }^{\circ} \mathrm{C}$ for $4 \mathrm{~h}$, the reaction mixture was filtered to remove the solid byproduct. The filtrate was diluted with dichloromethane and the solution was washed with water, and then dried over $\mathrm{Na}_{2} \mathrm{SO}_{4}$. After evaporating the solvent, compound 3e $(1.0 \mathrm{~g})$ was obtained as a yellow oil and was used for the next step without further purification.

3'. $N$-Formylglycine (166 mg, $1.61 \mathrm{mmol}), 3 \mathrm{e}(1.0 \mathrm{~g})$, and DMAP (232 $\mathrm{mg}, 1.90 \mathrm{mmol})$ were dissolved in anhydrous THF-DMSO $(1: 2, \mathrm{v} / \mathrm{v})(11 \mathrm{~mL})$ and the solution was cooled to $0{ }^{\circ} \mathrm{C}$. To this solution was added EDC-HCl $(364 \mathrm{mg}, 1.90 \mathrm{mmol})$ and the mixture was stirred at room temperature for $12 \mathrm{~h}$. The mixture was diluted with dichloromethane and the solution was washed with $1 \mathrm{~N} \mathrm{HCl}$ aqueous solution, saturated sodium hydrogen carbonate aqueous solution, and water, and then dried over $\mathrm{Na}_{2} \mathrm{SO}_{4}$. The solvent was removed under reduced pressure and the crude product was purified by silica gel chromatography using ethyl acetate as the eluent to give the desired product as a yellow solid (0.41 g, 40\% yield over 2 steps). ${ }^{1} \mathrm{H}$ NMR (500 MHz, $\left.\mathrm{CDCl}_{3}, \mathrm{rt}\right): \delta 8.24(\mathrm{~s}, 1 \mathrm{H}, \mathrm{CHO}), 7.42(\mathrm{~s}, 1 \mathrm{H}$, ArH), 7.39 (s, 1H, ArH), 7.15 (d, J=3.4 Hz, 1H, ArH), 7.13 (d, $J=3.4$ Hz, 1H, ArH), 6.80 (d, $J=3.4$ $\mathrm{Hz}, 1 \mathrm{H}, \mathrm{ArH}), 6.74$ (d, J=3.4 Hz, 1H, ArH), 6.39 (s, 1H, NH), 6.14 (t, J=5.7 Hz, 1H, NH), 4.25-4.28 $\left(\mathrm{m}, 4 \mathrm{H}, \mathrm{OCH}_{2}\right), 3.97\left(\mathrm{~d}, J=5.2 \mathrm{~Hz}, 2 \mathrm{H}, \mathrm{CH}_{2}\right), 3.60\left(\mathrm{q}, J=6.3 \mathrm{~Hz}, 2 \mathrm{H}, \mathrm{CH}_{2}\right), 3.06(\mathrm{t}, J=6.6 \mathrm{~Hz}, 2 \mathrm{H}$, $\mathrm{CH}_{2}$ ), 2.83 (t, $J=7.4 \mathrm{~Hz}, 2 \mathrm{H}, \mathrm{CH}_{2}$ ), 1.86-1.92 (m, 4H, $\mathrm{CH}_{2}$ ), 1.72 (quint, $\left.J=7.4 \mathrm{~Hz}, 2 \mathrm{H}, \mathrm{CH}_{2}\right), 1.58$ (q, $\left.J=7.1 \mathrm{~Hz}, 4 \mathrm{H}, \mathrm{CH}_{2}\right), 1.31-1.43\left(\mathrm{~m}, 14 \mathrm{H}, \mathrm{CH}_{2}\right), 0.89-0.95\left(\mathrm{~m}, 9 \mathrm{H}, \mathrm{CH}_{3}\right)$. 
2L'. $N$-Formyl-L-alanine (78 $\mathrm{mg}, 0.67 \mathrm{mmol})$ was added to a solution of $\mathbf{3 e}(0.41 \mathrm{~g})$ and $\mathrm{HOBt}(98$ $\mathrm{mg}, 0.73 \mathrm{mmol})$ in anhydrous THF-DMSO $(1: 2, \mathrm{v} / \mathrm{v})(4.5 \mathrm{~mL})$ and the mixture was cooled to $0{ }^{\circ} \mathrm{C}$ under a dry nitrogen atmosphere. To this mixture was added EDC-HCl (0.14 g, $0.73 \mathrm{mmol})$. After stirring at $-5{ }^{\circ} \mathrm{C}$ for $12 \mathrm{~h}$, the reaction system was diluted with dichloromethane and the solution was washed with saturated sodium hydrogen carbonate aqueous solution and water, and then dried over $\mathrm{Na}_{2} \mathrm{SO}_{4}$. After filtration, the solvent was removed under reduced pressure, followed by recrystallization from a hexane-ethyl acetate mixture to give the desired product as a yellow solid (0.31 g, 66\% yield). ${ }^{1} \mathrm{H}$ NMR $\left(500 \mathrm{MHz}, \mathrm{CDCl}_{3}, \mathrm{rt}\right): \delta 8.17(\mathrm{~s}, 1 \mathrm{H}, \mathrm{CHO}), 7.42(\mathrm{~s}, 1 \mathrm{H}, \mathrm{ArH}), 7.40(\mathrm{~s}, 1 \mathrm{H}, \mathrm{ArH}), 7.15(\mathrm{~d}, J=$ $3.4 \mathrm{~Hz}, 1 \mathrm{H}, \mathrm{ArH}), 7.13$ (d, J=4.0 Hz, 1H, ArH), 6.80 (d, J=3.4 Hz, 1H, ArH), 6.74 (d, J=4.0 Hz, 1H, $\operatorname{ArH}), 6.21(\mathrm{~d}, J=7.4 \mathrm{~Hz}, 1 \mathrm{H}, \mathrm{NH}), 6.13(\mathrm{~d}, J=7.4 \mathrm{~Hz}, 1 \mathrm{H}, \mathrm{NH}), 4.52$ (quint, $J=7.3 \mathrm{~Hz}, 1 \mathrm{H}, \mathrm{CH}$ ), 4.25-4.28 (m, 4H, $\left.\mathrm{OCH}_{2}\right), 3.53-3.64\left(\mathrm{~m}, 2 \mathrm{H}, \mathrm{CH}_{2}\right), 3.06\left(\mathrm{t}, J=6.6 \mathrm{~Hz}, 2 \mathrm{H}, \mathrm{CH}_{2}\right), 2.83(\mathrm{t}, J=7.7 \mathrm{~Hz}$, $2 \mathrm{H}, \mathrm{CH}_{2}$ ), 1.90 (quint, $J=7.3 \mathrm{~Hz}, 4 \mathrm{H}, \mathrm{CH}_{2}$ ), 1.72 (quint, $J=7.4 \mathrm{~Hz}, 2 \mathrm{H}, \mathrm{CH}_{2}$ ), 1.54-1.60 (m, 4H, $\mathrm{CH}_{2}$ ), 1.31-1.43 (m, 17H, $\left.\mathrm{CH}_{2}, \mathrm{CH}_{3}\right), 0.89-0.96\left(\mathrm{~m}, 9 \mathrm{H}, \mathrm{CH}_{3}\right)$.

2D'. The title compound 2D' was prepared from $N$-formyl-D-alanine in the same way for $2 \mathbf{L}$ ' and obtained in $52 \%$ yield as a yellow solid. ${ }^{1} \mathrm{H} \mathrm{NMR}\left(500 \mathrm{MHz}, \mathrm{CDCl}_{3}, \mathrm{rt}\right): \delta 8.16(\mathrm{~s}, 1 \mathrm{H}, \mathrm{CHO}), 7.41(\mathrm{~s}$, 1H, ArH), 7.39 (s, 1H, ArH), 7.14 (d, J=4.0 Hz, 1H, ArH), 7.13 (d, J=3.4 Hz, 1H, ArH), 6.79 (d, J= $3.4 \mathrm{~Hz}, 1 \mathrm{H}, \mathrm{ArH}), 6.74(\mathrm{~d}, J=3.4 \mathrm{~Hz}, 1 \mathrm{H}, \mathrm{ArH}), 6.30$ (d, J=7.4 Hz, 1H, NH), 6.25 (d, J=7.4 Hz, 1H, $\mathrm{NH}), 4.52$ (quint, $J=7.3 \mathrm{~Hz}, 1 \mathrm{H}, \mathrm{CH}), 4.25-4.28\left(\mathrm{~m}, 4 \mathrm{H}, \mathrm{OCH}_{2}\right), 3.54-3.64\left(\mathrm{~m}, 2 \mathrm{H}, \mathrm{CH}_{2}\right), 3.06(\mathrm{t}, J=$ $6.3 \mathrm{~Hz}, 2 \mathrm{H}, \mathrm{CH}_{2}$ ), 2.83 (t, $J=7.4 \mathrm{~Hz}, 2 \mathrm{H}, \mathrm{CH}_{2}$ ), 1.89 (quint, $J=7.3 \mathrm{~Hz}, 4 \mathrm{H}, \mathrm{CH}_{2}$ ), 1.71 (quint, $J=7.4$ $\left.\mathrm{Hz}, 2 \mathrm{H}, \mathrm{CH}_{2}\right), 1.55-1.61\left(\mathrm{~m}, 4 \mathrm{H}, \mathrm{CH}_{2}\right), 1.31-1.43$ (m, 17H, $\left.\mathrm{CH}_{2}, \mathrm{CH}_{3}\right), 0.89-0.95$ (m, 9H, $\left.\mathrm{CH}_{3}\right)$.

3. To a solution of $\mathbf{3}^{\prime}(371 \mathrm{mg}, 0.484 \mathrm{mmol})$ in anhydrous dichloromethane $(48 \mathrm{~mL})$ was added $N$-methylmorpholine $(0.21 \mathrm{~mL}, 1.9 \mathrm{mmol})$ and the mixture was cooled to $0{ }^{\circ} \mathrm{C}$ under a dry nitrogen atmosphere. To this mixture was added a solution of diphosgene (53 $\mathrm{mg}, 0.27 \mathrm{mmol})$ in dichloromethane $(3.2 \mathrm{~mL})$ over a period of $1 \mathrm{~h}$ and the reaction was quenched by adding saturated sodium hydrogen carbonate aqueous solution. After vigorous stirring for $5 \mathrm{~min}$, the resulting mixture was diluted with dichloromethane and the solution was washed with saturated sodium hydrogen carbonate aqueous solution and water, and then dried over $\mathrm{Na}_{2} \mathrm{SO}_{4}$. After filtration, the solvent was removed by evaporation and the crude product was purified by silica gel chromatography using dichloromethane as the eluent to give 3 as a yellow solid (285 mg, 79\% yield). Mp: $120.2-120.7^{\circ} \mathrm{C}$. IR $\left(\mathrm{KBr}, \mathrm{cm}^{-1}\right): 2159(\mathrm{~N} \equiv \mathrm{C}), 1655(\mathrm{C}=\mathrm{O}) .{ }^{1} \mathrm{H} \mathrm{NMR}\left(500 \mathrm{MHz}, \mathrm{CDCl}_{3}, \mathrm{rt}\right): \delta 7.43(\mathrm{~s}, 1 \mathrm{H}, \operatorname{ArH}), 7.39(\mathrm{~s}$, 
1H, ArH), 7.16 (d, J=4.0 Hz, 1H, ArH), 7.13 (d, J=3.4 Hz, 1H, ArH), 6.83 (d, $J=3.4 \mathrm{~Hz}, 1 \mathrm{H}, \operatorname{ArH})$, $6.74(\mathrm{~d}, J=3.4 \mathrm{~Hz}, 1 \mathrm{H}, \mathrm{ArH}), 6.58(\mathrm{t}, J=5.2 \mathrm{~Hz}, 1 \mathrm{H}, \mathrm{NH}), 4.25-4.28\left(\mathrm{~m}, 4 \mathrm{H}, \mathrm{OCH}_{2}\right), 4.18(\mathrm{~s}, 2 \mathrm{H}$, $\left.\mathrm{CH}_{2}\right), 3.65\left(\mathrm{q}, J=6.5 \mathrm{~Hz}, 2 \mathrm{H}, \mathrm{CH}_{2}\right), 3.10\left(\mathrm{t}, J=6.6 \mathrm{~Hz}, 2 \mathrm{H}, \mathrm{CH}_{2}\right), 2.83\left(\mathrm{t}, J=7.4 \mathrm{~Hz}, 2 \mathrm{H}, \mathrm{CH}_{2}\right), 1.90$ (quint, $J=7.3 \mathrm{~Hz}, 4 \mathrm{H}, \mathrm{CH}_{2}$ ), 1.72 (quint, $J=7.4 \mathrm{~Hz}, 2 \mathrm{H}, \mathrm{CH}_{2}$ ), 1.56-1.61 (m, 4H, $\mathrm{CH}_{2}$ ), 1.31-1.44 (m, 14H, $\left.\mathrm{CH}_{2}\right), 0.89-0.96\left(\mathrm{~m}, 9 \mathrm{H}, \mathrm{CH}_{3}\right) .{ }^{13} \mathrm{C} \mathrm{NMR}\left(126 \mathrm{MHz}, \mathrm{CDCl}_{3}, \mathrm{rt}\right): \delta 162.61,162.34,147.00,143.88$, $143.70,140.73,137.23,136.51,136.19,134.72,132.58,132.14,129.30,129.26,126.70,125.25$, $125.10,125.03,115.89,115.07,73.95,45.30,40.99,31.65,31.56,30.47,30.27,29.90,28.76,25.72$, 22.69, 22.58, 14.14. Calcd for $\mathrm{C}_{41} \mathrm{H}_{52} \mathrm{~N}_{2} \mathrm{O}_{3} \mathrm{~S}_{4} \cdot 0.1 \mathrm{H}_{2} \mathrm{O}: \mathrm{C}, 65.58 ; \mathrm{H}, 7.01 ; \mathrm{N}, 3.73$. Found: C, 65.58; $\mathrm{H}$, 6.91; N, 3.75. HRMS (FAB): $m / z$ calcd. for $\mathrm{C}_{41} \mathrm{H}_{52} \mathrm{~N}_{2} \mathrm{O}_{3} \mathrm{~S}_{4}\left(\mathrm{M}^{+}\right)$, 748.2855; found 748.2855.

2L. To a solution of 2L' (310 $\mathrm{mg}, 0.396 \mathrm{mmol})$ in anhydrous dichloromethane (40 $\mathrm{mL})$ was added $N$-methylmorpholine $(0.18 \mathrm{~mL}, 1.6 \mathrm{mmol})$ and the mixture was cooled to $-40{ }^{\circ} \mathrm{C}$ under a dry nitrogen atmosphere. To this mixture was added a solution of diphosgene (44 $\mathrm{mg}, 0.22 \mathrm{mmol}$ ) in dichloromethane $(2.6 \mathrm{~mL})$ over a period of $1 \mathrm{~h}$ and the reaction was quenched by adding saturated sodium hydrogen carbonate aqueous solution. After vigorous stirring for $5 \mathrm{~min}$, the resulting mixture was diluted with dichloromethane and the solution was washed with saturated sodium hydrogen carbonate aqueous solution and water, and then dried over $\mathrm{Na}_{2} \mathrm{SO}_{4}$. After filtration, the solvent was removed by evaporation and the crude product was purified by silica gel chromatography using dichloromethane as the eluent to give $\mathbf{2 L}$ as a yellow solid (132 $\mathrm{mg}, 44 \%$ yield). 2L was further purified by chiral HPLC on CHIRALPAK IA $(25 \mathrm{~cm} \times 2.0 \mathrm{~cm}$ (i.d.); eluent, hexane-dichloromethane $(55: 45, \mathrm{v} / \mathrm{v})$; flow rate, $10 \mathrm{~mL} \mathrm{~min}^{-1}$; temperature, $\left.\mathrm{ca} .20^{\circ} \mathrm{C}\right)$ to enhance its enantiopurity up to $>99.8 \%$ ee. Mp: $111.9-112.4{ }^{\circ} \mathrm{C}$. $[\alpha]^{25} \mathrm{D}+10.0$ (c 1.0, chloroform). IR $\left(\mathrm{KBr}, \mathrm{cm}^{-1}\right): 2153(\mathrm{~N} \equiv \mathrm{C}), 1664(\mathrm{C}=\mathrm{O})$. ${ }^{1} \mathrm{H}$ NMR (500 MHz, $\left.\mathrm{CDCl}_{3}, \mathrm{rt}\right): \delta 7.43$ (s, 1H, ArH), 7.40 (s, 1H, ArH), 7.16 (d, J=3.4 Hz, 1H, ArH), $7.13(\mathrm{~d}, J=3.4 \mathrm{~Hz}, 1 \mathrm{H}, \mathrm{ArH}), 6.83(\mathrm{~d}, J=3.4 \mathrm{~Hz}, 1 \mathrm{H}, \mathrm{ArH}), 6.74(\mathrm{~d}, J=3.4 \mathrm{~Hz}, 1 \mathrm{H}, \operatorname{ArH}), 6.60$ (t, $J=$ $5.4 \mathrm{~Hz}, 1 \mathrm{H}, \mathrm{NH}), 4.24-4.28\left(\mathrm{~m}, 5 \mathrm{H}, \mathrm{OCH}_{2}, \mathrm{CH}\right), 3.62\left(\mathrm{q}, J=6.3 \mathrm{~Hz}, 2 \mathrm{H}, \mathrm{CH}_{2}\right), 3.10$ (t, J=6.6 Hz, 2H, $\mathrm{CH}_{2}$ ), 2.83 (t, $J=7.7 \mathrm{~Hz}, 2 \mathrm{H}, \mathrm{CH}_{2}$ ), 1.90 (quint, $J=7.3 \mathrm{~Hz}, 4 \mathrm{H}, \mathrm{CH}_{2}$ ), 1.72 (quint, $J=7.4 \mathrm{~Hz}, 2 \mathrm{H}$, $\left.\mathrm{CH}_{2}\right), 1.66\left(\mathrm{~d}, J=7.4 \mathrm{~Hz}, 3 \mathrm{H}, \mathrm{CH}_{3}\right), 1.57-1.61$ (m, 4H, $\left.\mathrm{CH}_{2}\right), 1.31-1.43$ (m, 14H, $\left.\mathrm{CH}_{2}\right), 0.89-0.96$ (m, $\left.9 \mathrm{H}, \mathrm{CH}_{3}\right) .{ }^{13} \mathrm{C} \mathrm{NMR}\left(126 \mathrm{MHz}, \mathrm{CDCl}_{3}, \mathrm{rt}\right): \delta 166.14,161.35,147.00,143.90,143.73,140.86,137.23$, $136.50,136.25,134.76,132.58,132.16,129.32,129.27,126.69$, 125.25, 125.10, 125.04, 115.89, $115.11,73.95,53.52,41.05,31.66,31.56,30.47,30.28,29.92,28.76,25.72,22.69,22.58,19.76,14.12$. Calcd for $\mathrm{C}_{42} \mathrm{H}_{54} \mathrm{~N}_{2} \mathrm{O}_{3} \mathrm{~S}_{4} \cdot 0.3 \mathrm{H}_{2} \mathrm{O}$ : C, 65.64; H, 7.16; N, 3.65. Found: C, 65.63; H, 7.00; N, 3.63. HRMS 
(FAB): $m / z$ calcd. for $\mathrm{C}_{42} \mathrm{H}_{54} \mathrm{~N}_{2} \mathrm{O}_{3} \mathrm{~S}_{4}\left(\mathrm{M}^{+}\right), 762.3012$; found 762.3023 .

2D. The title compound 2D ( $>99.8 \%$ ee) was prepared from $\mathbf{2 D}$ ' in the same way for $\mathbf{2} \mathbf{L}$ and obtained as a yellow solid (112 mg, 49\% yield). Mp: $112.0-112.5^{\circ} \mathrm{C} .[\alpha]^{25} \mathrm{D}-10.0$ (c 1.0, chloroform). IR (KBr, cm $\left.{ }^{-1}\right): 2154(\mathrm{~N} \equiv \mathrm{C}), 1662(\mathrm{C}=\mathrm{O}) .{ }^{1} \mathrm{H}$ NMR $\left(500 \mathrm{MHz}, \mathrm{CDCl}_{3}, \mathrm{rt}\right): \delta 7.43(\mathrm{~s}, 1 \mathrm{H}, \mathrm{ArH}), 7.40(\mathrm{~s}$, 1H, ArH), 7.17 (d, J=3.4 Hz, 1H, ArH), 7.13 (d, J=3.4 Hz, 1H, ArH), 6.83 (d, J=3.4 Hz, 1H, ArH), $6.74(\mathrm{~d}, J=3.4 \mathrm{~Hz}, 1 \mathrm{H}, \mathrm{ArH}), 6.60(\mathrm{t}, J=5.4 \mathrm{~Hz}, 1 \mathrm{H}, \mathrm{NH}), 4.24-4.28\left(\mathrm{~m}, 5 \mathrm{H}, \mathrm{OCH}_{2}, \mathrm{CH}\right), 3.62(\mathrm{q}, J=$ $\left.6.5 \mathrm{~Hz}, 2 \mathrm{H}, \mathrm{CH}_{2}\right), 3.10$ (t, $\left.J=6.9 \mathrm{~Hz}, 2 \mathrm{H}, \mathrm{CH}_{2}\right), 2.83$ (t, $J=7.7 \mathrm{~Hz}, 2 \mathrm{H}, \mathrm{CH}_{2}$ ), 1.90 (quint, $J=7.3 \mathrm{~Hz}$, 4H, $\mathrm{CH}_{2}$ ), 1.72 (quint, $J=7.4 \mathrm{~Hz}, 2 \mathrm{H}, \mathrm{CH}_{2}$ ), 1.66 (d, $\left.J=6.9 \mathrm{~Hz}, 3 \mathrm{H}, \mathrm{CH}_{3}\right), 1.57-1.60\left(\mathrm{~m}, 4 \mathrm{H}_{2} \mathrm{CH}_{2}\right)$, 1.31-1.42 (m, 14H, CH 2$), 0.89-0.96\left(\mathrm{~m}, 9 \mathrm{H}, \mathrm{CH}_{3}\right) .{ }^{13} \mathrm{C} \mathrm{NMR}\left(126 \mathrm{MHz}, \mathrm{CDCl}_{3}, \mathrm{rt}\right): \delta 166.14,161.34$, $147.00,143.90,143.73,140.85,137.23,136.50,136.24,134.75,132.58,132.16,129.32,129.27$, $126.70,125.25,125.10,125.04,115.90,115.11,73.94,53.52,41.05,31.66,31.56,30.47,30.28,29.93$, 28.76, 25.72, 22.69, 22.58, 19.76, 14.13. Calcd for $\mathrm{C}_{42} \mathrm{H}_{54} \mathrm{~N}_{2} \mathrm{O}_{3} \mathrm{~S}_{4} \cdot 0.3 \mathrm{H}_{2} \mathrm{O}: \mathrm{C}, 65.79 ; \mathrm{H}, 7.15 ; \mathrm{N}, 3.65$. Found: C, 65.86; H, 7.03; N, 3.67. HRMS (FAB): $m / z$ calcd. for $\mathrm{C}_{42} \mathrm{H}_{54} \mathrm{~N}_{2} \mathrm{O}_{3} \mathrm{~S}_{4}\left(\mathrm{M}^{+}\right), 762.3012$; found 762.3019 .

4. 2-Propyl-1-pentanol (3.6 mL, $23 \mathrm{mmol})$, triethylamine $(6.4 \mathrm{~mL}, 46 \mathrm{mmol})$, and trimethylamine hydrochloride $(1.1 \mathrm{~g}, 12 \mathrm{mmol})$ were dissolved in anhydrous dichloromethane $(23 \mathrm{~mL})$ and the mixture was cooled to $0{ }^{\circ} \mathrm{C}$ under a dry nitrogen atmosphere. To this mixture was added dropwise an anhydrous dichloromethane solution $(23 \mathrm{~mL})$ of $p$-toluenesulfonyl chloride $(5.7 \mathrm{~g}, 30 \mathrm{mmol})$ at $0{ }^{\circ} \mathrm{C}$. After stirring at $0{ }^{\circ} \mathrm{C}$ for $4 \mathrm{~h}$, the reaction solution was diluted with ethyl acetate and the solution was washed with 1 $\mathrm{N} \mathrm{HCl}$ aqueous solution, saturated sodium hydrogen carbonate aqueous solution, and water, and then dried over $\mathrm{Na}_{2} \mathrm{SO}_{4}$. The solvent was removed under reduced pressure and the crude product was purified by silica gel chromatography using $n$-hexane-ethyl acetate $(15: 1, \mathrm{v} / \mathrm{v})$ as the eluent to give the desired product as a colorless oil $(6.1 \mathrm{~g}, 93 \%$ yield $) .{ }^{1} \mathrm{H} \mathrm{NMR}\left(500 \mathrm{MHz}, \mathrm{CDCl}_{3}, \mathrm{rt}\right): \delta 7.79(\mathrm{~d}, J=8.0$ $\mathrm{Hz}, 2 \mathrm{H}, \mathrm{ArH}), 7.35$ (d, $J=8.0 \mathrm{~Hz}, 2 \mathrm{H}, \mathrm{ArH}), 3.91\left(\mathrm{~d}, J=5.7 \mathrm{~Hz}, 2 \mathrm{H}, \mathrm{CH}_{2}\right), 2.45\left(\mathrm{~s}, 3 \mathrm{H}, \mathrm{CH}_{3}\right)$, 1.60-1.64 (m, 1H, CH), 1.15-1.29 (m, 8H, $\left.\mathrm{CH}_{2}\right), 0.83\left(\mathrm{t}, J=6.9 \mathrm{~Hz}, 6 \mathrm{H}, \mathrm{CH}_{3}\right)$.

ANT. To a mixture of $4(0.81 \mathrm{~g}, 2.8 \mathrm{mmol})$ and 2,6-dihydroxyanthracene $(0.10 \mathrm{~g}, 0.47 \mathrm{mmol})$ in anhydrous DMF $(1.9 \mathrm{~mL})$ was added potassium carbonate $(0.20 \mathrm{~g}, 1.4 \mathrm{mmol})$. The mixture was stirred at $100{ }^{\circ} \mathrm{C}$ for $16 \mathrm{~h}$. After quenching the reaction with water, the mixture was diluted with ethyl acetate and the solution was washed with water, and then dried over $\mathrm{Na}_{2} \mathrm{SO}_{4}$. The solvent was removed under 
reduced pressure and the crude product was purified by silica gel chromatography using $n$-hexaneethyl acetate $(10: 1, \mathrm{v} / \mathrm{v})$ as the eluent to give the desired product as a pale yellow solid $(0.13 \mathrm{~g}, 61 \%$ yield). Mp: $74.1-74.6{ }^{\circ} \mathrm{C} .{ }^{1} \mathrm{H}$ NMR $\left(500 \mathrm{MHz}, \mathrm{CDCl}_{3}, \mathrm{rt}\right): \delta 8.16$ (s, 2H, ArH), $7.83(\mathrm{~d}, J=9.7 \mathrm{~Hz}, 2 \mathrm{H}$, $\operatorname{ArH}$ ), 7.14-7.15 (m, 4H, ArH), 3.98 (d, $J=5.7 \mathrm{~Hz}, 4 \mathrm{H}, \mathrm{OCH}_{2}$ ), 1.90 (quint, $J=5.7 \mathrm{~Hz}, 2 \mathrm{H}, \mathrm{CH}$ ), 1.37-1.52 (m, 16H, $\left.\mathrm{CH}_{2}\right), 0.90-0.96\left(\mathrm{~m}, 12 \mathrm{H}, \mathrm{CH}_{3}\right) .{ }^{13} \mathrm{C} \mathrm{NMR}\left(126 \mathrm{MHz}, \mathrm{CDCl}_{3}, \mathrm{rt}\right): \delta 156.16,131.22$, 129.05, 128.63, 124.06, 120.85, 104.44, 70.79, 37.51, 33.84, 20.05, 14.50. HRMS (FAB): m/z calcd. for $\mathrm{C}_{30} \mathrm{H}_{42} \mathrm{O}_{2}\left(\mathrm{M}^{+}\right), 434.3179$; found 434.3179 .

\subsection{Homopolymerization of a glycine-based isocyanide}

Homopolymerization of a glycine-based achiral isocyanide 3 was conducted with $\mathrm{Ni}\left(\mathrm{ClO}_{4}\right)_{2} \cdot 6 \mathrm{H}_{2} \mathrm{O}$ as a catalyst using a similar method to that reported previously. ${ }^{\mathrm{S} 6}$ Monomer 3 (10 mg, $\left.13 \mu \mathrm{mol}\right)$ was placed in a dry ampoule, which was then evacuated on a vacuum line and flushed with dry nitrogen. This evacuation-flush procedure was repeated three times, then a three-way stopcock was attached to the ampoule, and dry chloroform $(375 \mu \mathrm{L})$ was added with a syringe. To this was added $\mathrm{Ni}\left(\mathrm{ClO}_{4}\right)_{2} \cdot 6 \mathrm{H}_{2} \mathrm{O}$ (0.054 $\mathrm{mg}, 0.15 \mu \mathrm{mol})$ dissolved in chloroform, containing a small amount of ethanol (50:1, v/v; 52 $\mu \mathrm{L})$ to dissolve the nickel complex, at $-10{ }^{\circ} \mathrm{C}\left([3]_{0}=31.2 \mathrm{mM} ;[3]_{0} /[\mathrm{Ni}]_{0}=90\right)$. The mixture was stirred at $-10{ }^{\circ} \mathrm{C} .{ }^{\mathrm{S} 7}$ At predetermined intervals, an aliquot of the reaction mixture (approx. $10 \mu \mathrm{L}$ ) was withdrawn from the vessel and diluted with chloroform $(3.0 \mathrm{~mL})$ to stop the polymerization reaction. We confirmed that monomer consumption did not proceed after at least 100-fold dilution of the polymerization system with chloroform, even after 1 days. Monomer conversions were determined from the concentration of a residual monomer measured by SEC equipped with Tosoh TSKgel $\mathrm{G}^{1000 \mathrm{H}_{\mathrm{HR}}}$ using chloroform as the internal standard, using THF containing 0.25 wt $\%$ tetrabutylammonium bromide as the eluent. The chromatograms were recorded with UV detection at $254 \mathrm{~nm}$. The 1-D supramolecular structure of the resulting product (supra-poly(3)) was partially dissociated and not perfectly maintained through typical purification processes, including precipitation and washing. Thus, the completed polymerization systems were diluted with appropriate solvents, such as chloroform, THF, and a THF/DMSO mixture, and directly subjected to chromatographic and spectroscopic analysis, unless otherwise noted. For the same reason, ${ }^{1} \mathrm{H}$ NMR data of the isolated supra-poly(3) could not be obtained, but the spectrum could be measured after dissociation (vide infra). Copolymerizations procedures for an achiral glycine-based monomer and a chiral alanine-based monomer are summarized in Section 2.4 in the SI. 
2.3. Dissociation of 1-D supramolecular structures into macromolecular building blocks

Typical dissociation procedures were as follows. After the polymerization of $\mathbf{3}$ was complete, a portion of the reaction system was diluted approximately 300 -fold with THF/DMSO $(96: 4, \mathrm{v} / \mathrm{v})$ and allowed to stand at $25{ }^{\circ} \mathrm{C}$ until no further shift toward a lower molecular mass region was observed in the SEC trace $(\geq 120 \mathrm{~h})$. The DMSO content could not be increased owing to polymer solubility. After concentrating in vacuo, the residual solution was poured into a large amount of ethanol. The resulting precipitate was collected by centrifugation, washed with ethanol, and dried in vacuo. Consequently, the dissociated poly(3) was obtained as a brown solid $\left(M_{\mathrm{n}}=1.9 \times 10^{4}, M_{\mathrm{w}} / M_{\mathrm{n}}=1.9\right)$. IR $\left(\mathrm{KBr}, \mathrm{cm}^{-1}\right): 1659$ $(\mathrm{C}=\mathrm{O}) .{ }^{1} \mathrm{H}$ NMR $\left(500 \mathrm{MHz}, \mathrm{CDCl}_{3}, \mathrm{rt}\right): \delta 6.1-7.5$ (br, 7H, $\left.\mathrm{ArH}, \mathrm{NH}\right), 2.2-4.4\left(\mathrm{br}, 12 \mathrm{H}, \mathrm{CH}_{2}\right), 1.0-1.9$ (br, $\left.24 \mathrm{H}, \mathrm{CH}_{2}\right), 0.6-1.0$ (br, 9H, $\left.\mathrm{CH}_{3}\right)$. Anal. Calcd. for $\left(\mathrm{C}_{41} \mathrm{H}_{52} \mathrm{~N}_{2} \mathrm{O}_{3} \mathrm{~S}_{4} \cdot 0.7 \mathrm{H}_{2} \mathrm{O}\right)_{n}$ : C, 64.65; H, 7.07; N, 3.68. Found: $\mathrm{C}, 64.63 ; \mathrm{H}, 6.88 ; \mathrm{N}, 3.69$.

\subsection{Copolymerization of achiral and chiral isocyanide monomers}

Copolymerizations of an achiral glycine-based monomer and a chiral alanine-based monomer were carried out by changing monomer combinations and feed ratios in a similar manner to homopolymerization described in Section 2.2 in the SI. Initial feed ratios of comonomers were confirmed by HPLC on CHIRALPAK IE-3 (see Figure S9). However, when the mole fraction of one of the comonomers was $0.2 \%$ or less, the feed ratio could not be accurately determined by HPLC analysis due to a detection limit. In such cases, initial feed ratios were estimated from mixing ratios of two monomer solutions. The detailed copolymerization procedure using $\mathbf{3}$ and $\mathbf{2} \mathbf{L}$ at $[\mathbf{3}]_{0} /[\mathbf{2} \mathbf{L}]_{0}=99: 1$ is described below as a typical example.

To a solution of $3(10 \mathrm{mg}, 13 \mu \mathrm{mol})$ and $2 \mathbf{L}(0.10 \mathrm{mg}, 0.13 \mu \mathrm{mol})$ in chloroform $(379 \mu \mathrm{L})$ was added $\mathrm{Ni}\left(\mathrm{ClO}_{4}\right)_{2} \cdot 6 \mathrm{H}_{2} \mathrm{O}(0.054 \mathrm{mg}, 0.15 \mu \mathrm{mol})$ dissolved in chloroform/ethanol $(50: 1, \mathrm{v} / \mathrm{v} ; 53 \mu \mathrm{L})$ at $10{ }^{\circ} \mathrm{C}$ under a dry nitrogen atmosphere $\left([\mathbf{3}]_{0}=31.1 \mathrm{mM} ;[\mathbf{2} \mathbf{L}]_{0}=0.31 \mathrm{mM} ;[\mathbf{3}+\mathbf{2} \mathbf{L}]_{0} /[\mathrm{Ni}]_{0}=90\right)$. The mixture was stirred at $-10{ }^{\circ} \mathrm{C}$. In predetermined intervals, a portion of the reaction mixture (approx. 10 $\mu \mathrm{L})$ was withdrawn from the vessel and diluted with chloroform $(3.0 \mathrm{~mL})$ to terminate the polymerization. The total monomer conversions were determined by SEC equipped with Tosoh TSKgel G1000 $\mathrm{H}_{\mathrm{HR}}$ using a chloroform as the internal standard, where THF containing $0.25 \mathrm{wt} \%$ tetrabutylammonium bromide was used as the eluent and the chromatograms were recorded with UV detection at $254 \mathrm{~nm}$. The residual monomer ratios were determined by HPLC equipped with a CHIRALPAK IE-3 column. After complete consumption of both monomers, the reaction mixture was diluted with appropriate solvents and directly used for subsequent chromatographic and spectroscopic 
studies. This is because the 1-D supramolecular structure and helical chirality of the resulting product (supra-poly $\left(\mathbf{3}_{1-r}-c o-2 \mathbf{L}_{r}\right)$ ) were not perfectly maintained through typical purification processes, including precipitation and washing.

\section{Supporting experimental data}

\subsection{High-resolution AFM study}

A probe-scan-type atomic force microscope (AFM) (Cypher S, Oxford Instruments, UK) was used for the molecular imaging of supra-poly(3) (see Figures 2E and S2) and the completely-dissociated poly(3) (see Figure S5) in the dynamic (tapping) mode with a cantilever (160AC-NG, MikroMasch, Wetzlar, Germany) having a spring constant of $26 \mathrm{~N} \mathrm{~m}^{-1}$ and resonance frequency of $300 \mathrm{kHz}$ (typical values). A specimen for AFM imaging was prepared by spin-casting a chloroform solution of supra-poly(3) or the completely-dissociated poly $(3)$ (approx. $10^{-6} \mathrm{M}, 50 \mu \mathrm{L}$ ) onto a highly oriented pyrolytic graphite (HOPG) or mica substrate at ca. 1,500 rpm, respectively. AFM imaging was carried out at room temperature (ca. $20^{\circ} \mathrm{C}$ ) in air. High-resolution AFM imaging of supra-poly $\left(\mathbf{3}_{0.99-c o-2} \mathbf{L}_{0.01}\right)$ was also conducted in the same way as that of supra-poly(3) (Figures 3D and S15).

\subsection{Length evaluation of supra-poly(3) by high-resolution AFM imaging}

In the 6 AFM images of supra-poly(3), 57 supramolecular chains were found with the entire structures from end to end fitted inside the observation area (Figure S2). Based on the length measurement of curves traced along these supramolecular fibers (shown as black dashed lines in Figure S2B), the average chain length was calculated to be $183 \mathrm{~nm}$ (Figure S3A). If a 1-D supramolecular fiber had a too elongated geometry and a part of the chain structure was entangled, its length information could not be obtained and counted to estimate the average length. Thus, the average length evaluated here was considered an underestimated value, and longer supramolecular structures than the estimate would be produced in practice. 


\subsection{Influence of supra-poly $\left(\mathbf{3}_{1-r}-c o-2 \mathbf{L}_{r}\right)$ concentration in chloroform on chiroptical properties}

Because the present supramolecular systems were partially dissociated after isolation, as described in the main text and also Section 2.2 in the SI, we used polymerization solutions for (chir)optical measurements after diluting approx. 130-fold with chloroform. This made controlling the solution concentration precisely and obtaining a molar circular dichroism (or molar ellipticity) difficult. Therefore, we compared the Cotton effect intensities after normalization of CD spectra with the absorbance at the absorption maximum wavelength. To verify the validity of the results obtained in this manner, the absorption and CD spectra of supra-poly $\left(\mathbf{3}_{0.99}-c o-\mathbf{2} \mathbf{L}_{0.01}\right)$ were measured in chloroform by changing the concentration (Figure S13). As a result, concentration dependence was hardly observed, even under 100-fold dilute conditions, indicating that a certain amount of concentration variation of supra-poly $\left(\mathbf{3}_{1-r}-\right.$ co-2 $\left.\mathbf{L}_{r}\right)$ did not cause a significant difference in the chiroptical properties. In fact, all CD spectra shown in the following study were measured within the above concentration ranges. Therefore, we can confidently state that chiroptical data presented herein can be used to discuss the helix-sense excess of supra-poly $\left(\mathbf{3}_{1-r}-c o-2 \mathbf{L}_{r}\right)$ backbones.

3.4. Mixing study using the individually prepared supra-poly $\left(\mathbf{3}_{0.99-c o-2} \mathbf{L}_{0.01}\right)$ and supra-poly(3)

A copolymerization of $\mathbf{3}$ and $\mathbf{2 L}\left([\mathbf{3}]_{0} /[\mathbf{2} \mathbf{L}]_{0}=99: 1,[\mathbf{3}+\mathbf{2} \mathbf{L}]=31 \mathrm{mM}\right)$ and homopolymerization of $\mathbf{3}$

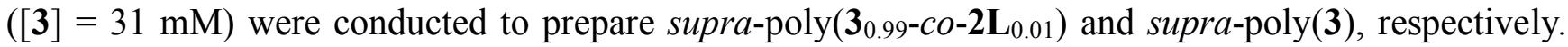
The completed two polymerization systems were mixed together at various volume ratios (Figure S28). As the total monomer concentrations in the two polymerization systems were the same, the volume ratios could be regarded as the molar ratios between supra-poly $\left(\mathbf{3}_{0.99}-c o-2 \mathbf{L}_{0.01}\right)$ and supra-poly(3). After the resulting mixtures were stirred at $-10{ }^{\circ} \mathrm{C}$ for $1 \mathrm{~h}$ and then diluted approx. 130-fold with chloroform, absorption and CD spectra were recorded (Figure S28A). We confirmed that the CD intensities of the supra-poly $\left(\mathbf{3}_{0.99}-\right.$ co-2 $\left.\mathbf{L}_{0.01}\right) /$ supra-poly(3) mixtures increased approximately linearly with the increasing molar ratio of supra-poly $\left(\mathbf{3}_{0.99-c o-2} \mathbf{L}_{0.01}\right)$ (Figure $\left.\mathrm{S} 28 \mathrm{~B}\right)$. This result indicated that chiral amplification in the preferred-handed helix formation did not occur between supramolecular fibers. 


\section{Supporting data}
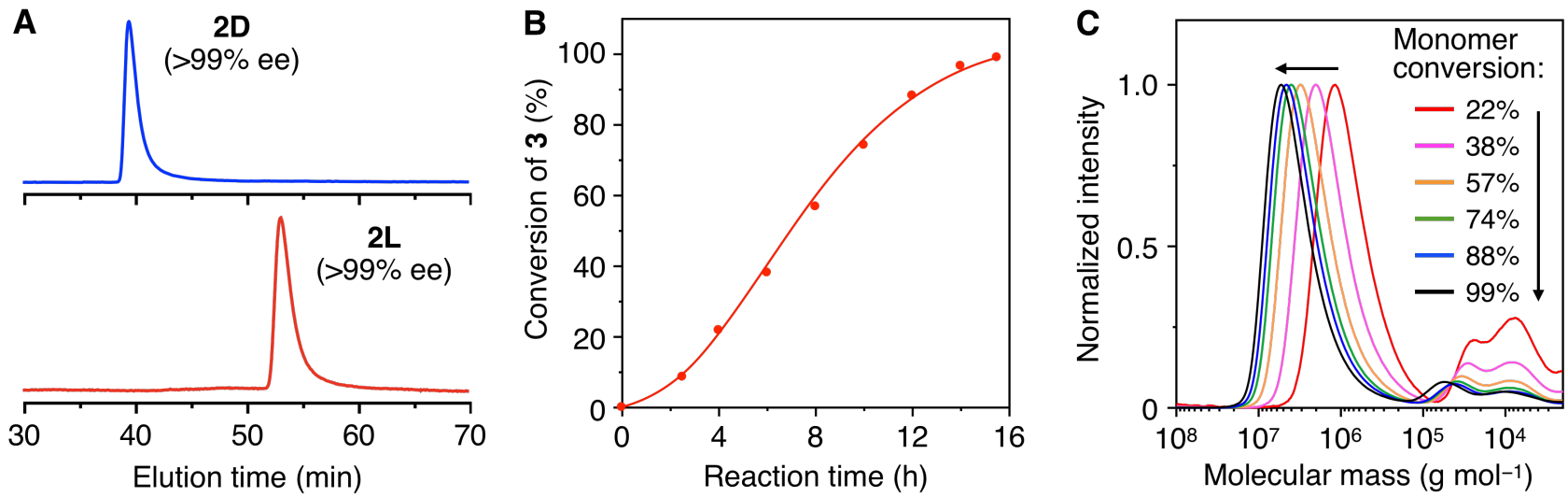

Figure S1. (A) Verification of high optical purities ( $>99 \%$ ee) of $2 \mathbf{D}$ (top) and $2 \mathbf{L}$ (bottom) by HPLC on CHIRALPAK IE-3 column $(25 \mathrm{~cm} \times 0.46 \mathrm{~cm}$ (i.d.) $)$ at ca. $20^{\circ} \mathrm{C}$. Chromatograms show UV traces

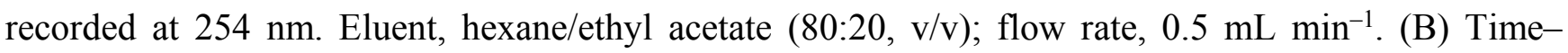
conversion curve and (C) conversion-dependent changes in SEC curves during the homopolymerization of 3 . Chromatograms show UV traces recorded at $254 \mathrm{~nm}$. 
A
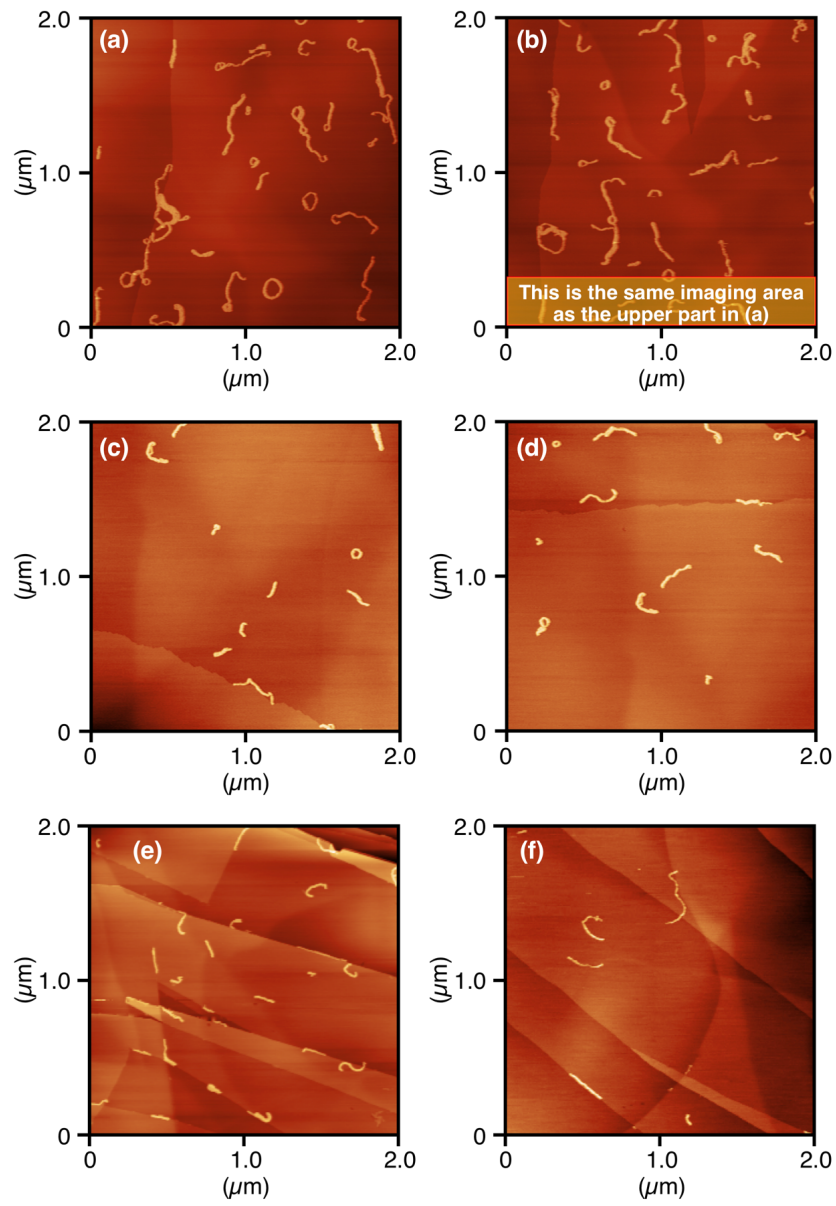

B
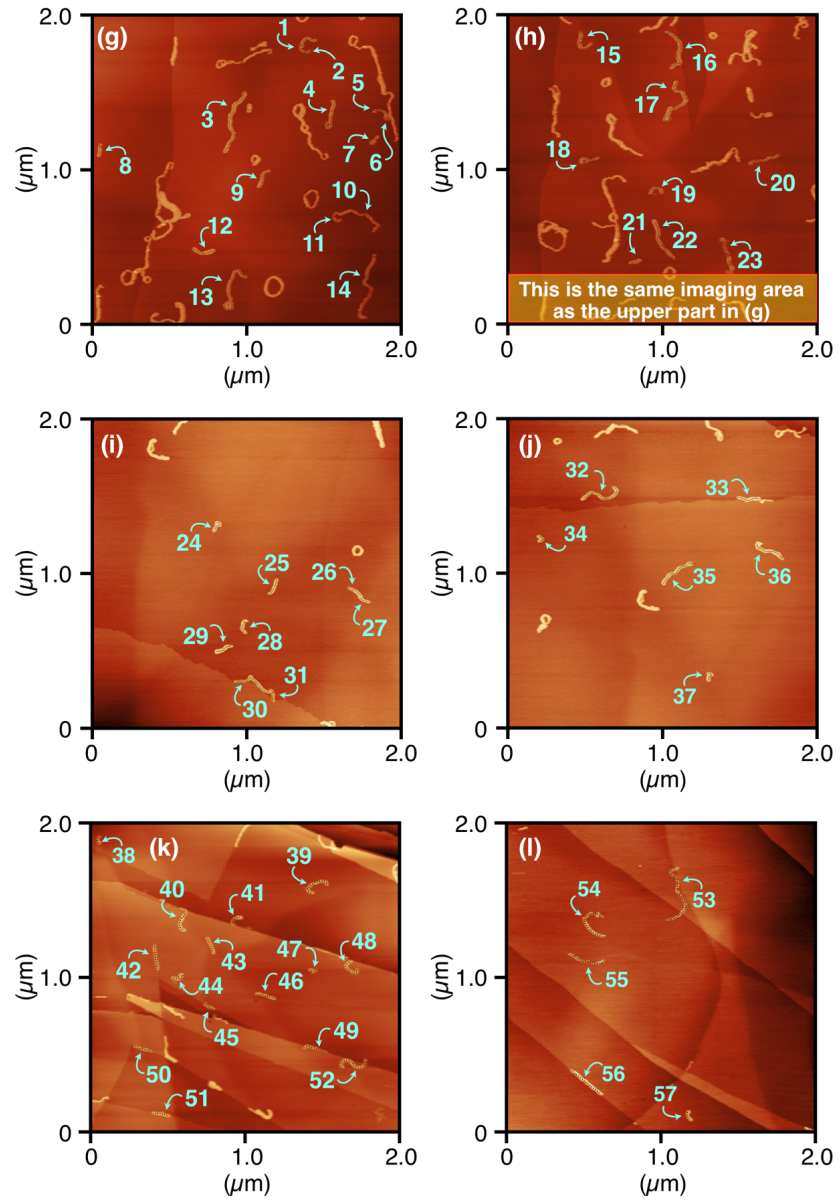

Figure S2. (A) AFM images $\left(2.0 \times 2.0 \mu \mathrm{m}^{2}\right)$ of supra-poly(3) on HOPG in air at ca. $20^{\circ} \mathrm{C}$. A specimen was prepared by spin-casting the reaction system diluted with chloroform after polymerization was complete. (B) Same AFM images as in (A), but showing black dashed lines that trace the single supramolecular chains. The images of (g)-(l) are corresponding to those of (a)-(f) in (A), respectively. Numbers 1-57 correspond to those in Figure S3A. 


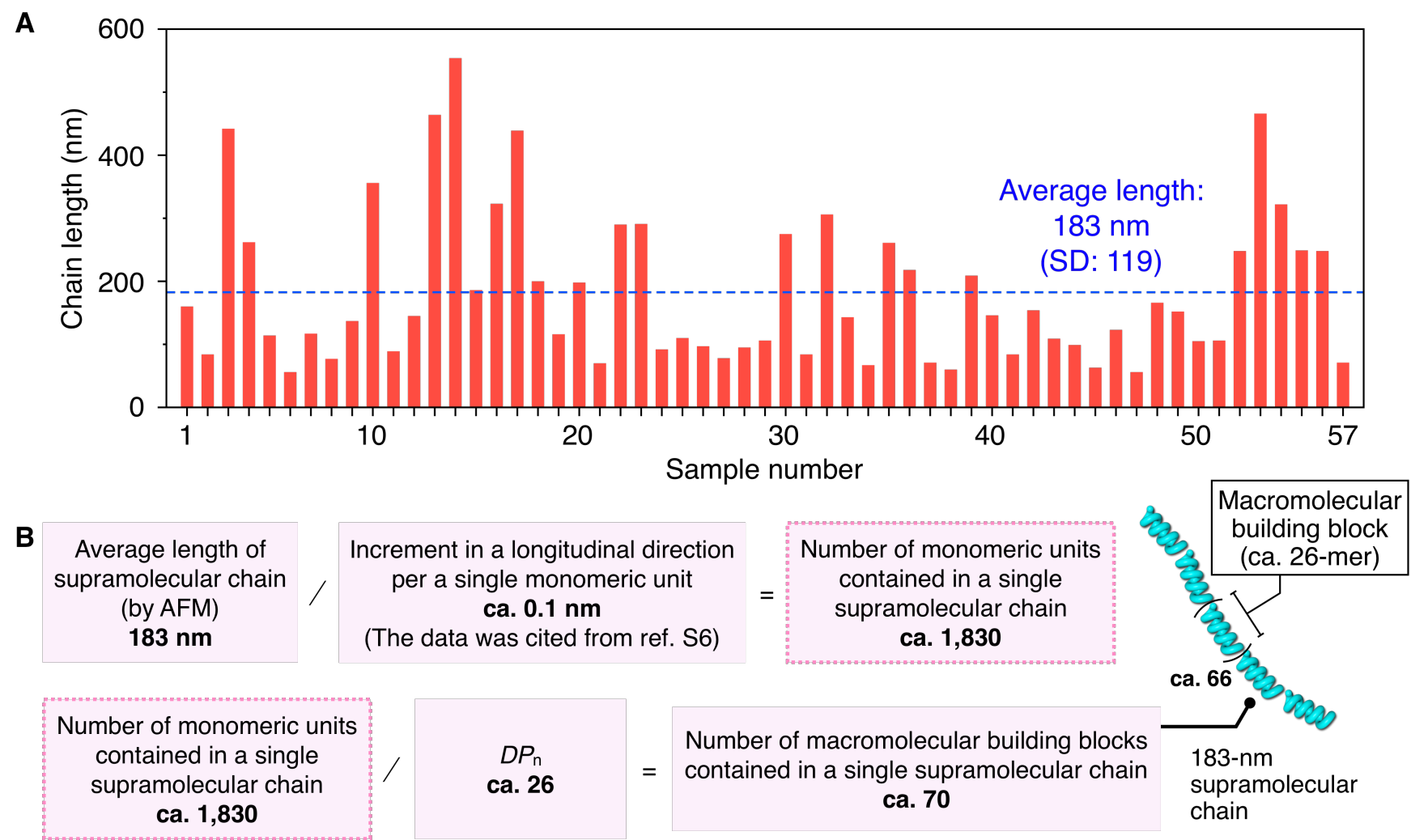

Figure S3. (A) Chain-length statistics of supra-poly(3) based on the results of high-resolution AFM imaging showing in Figure S2. The number of samples was 57. (B) Derivation of the numbers of monomeric units and macromolecular building blocks contained in a 183-nm single supramolecular chain. 

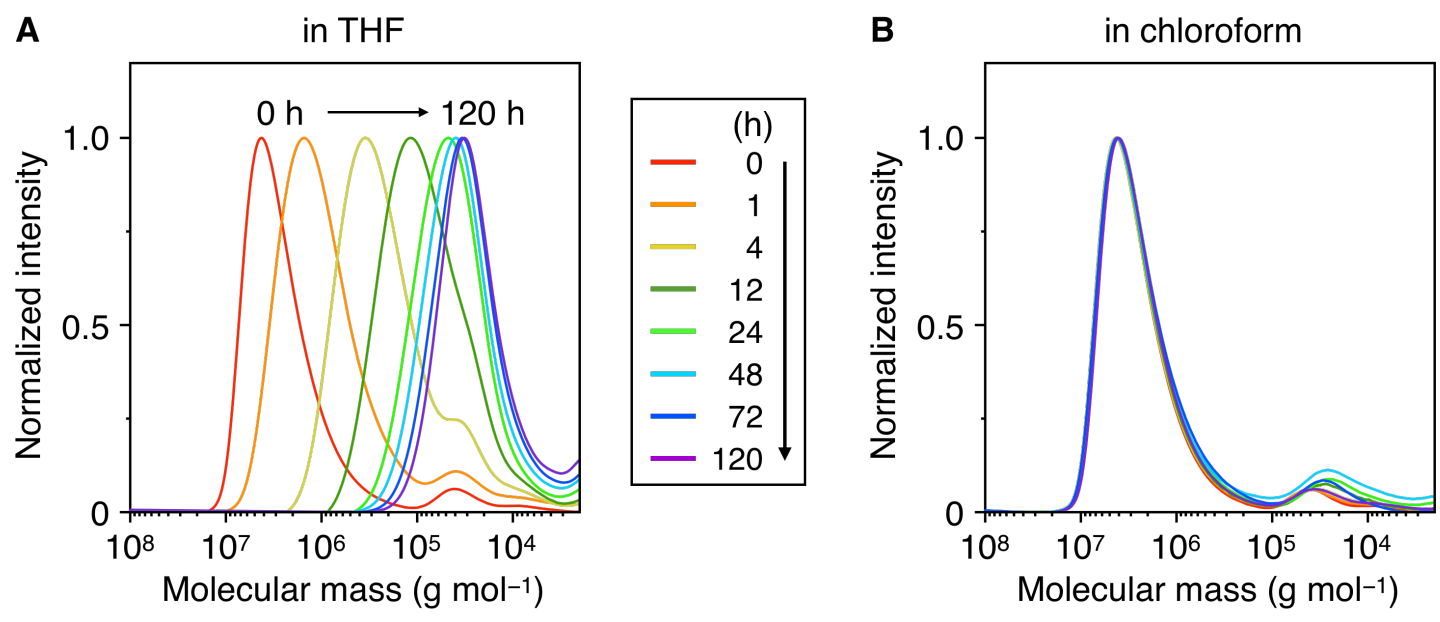

Figure S4. Time-dependent changes of SEC traces of the 3-derived polymerization product (supra-poly(3)) while keeping the completed reaction system at $25{ }^{\circ} \mathrm{C}$ after diluting 300 -fold with (A) THF and (B) chloroform.

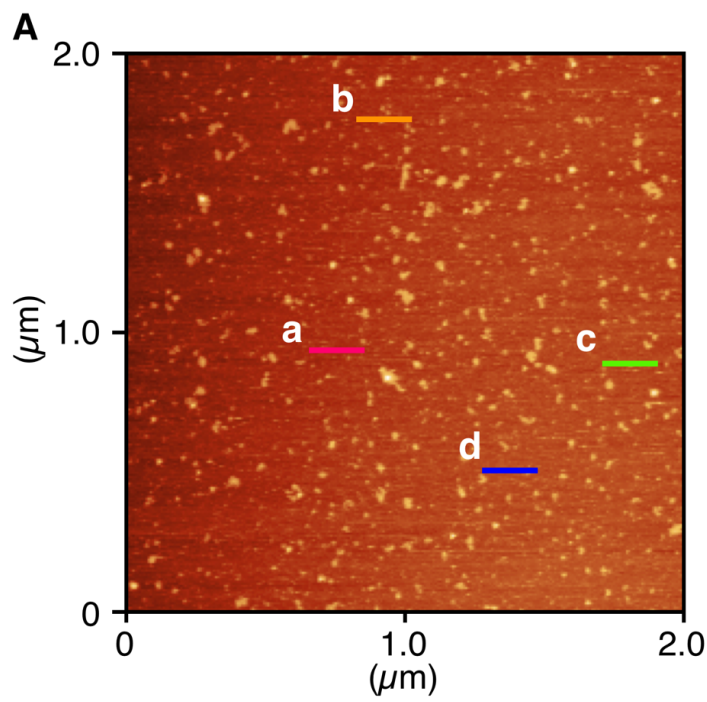

B

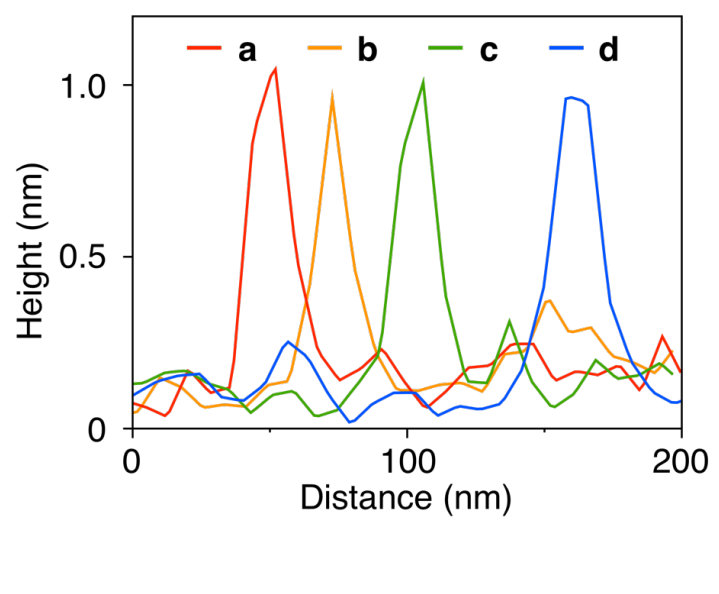

Figure S5. (A) AFM image $\left(2.0 \times 2.0 \mu \mathrm{m}^{2}\right)$ of completely dissociated poly $(3)$ on mica in air at ca. $20^{\circ} \mathrm{C}$. (B) Height profiles measured along lines labeled a-d in (A). 


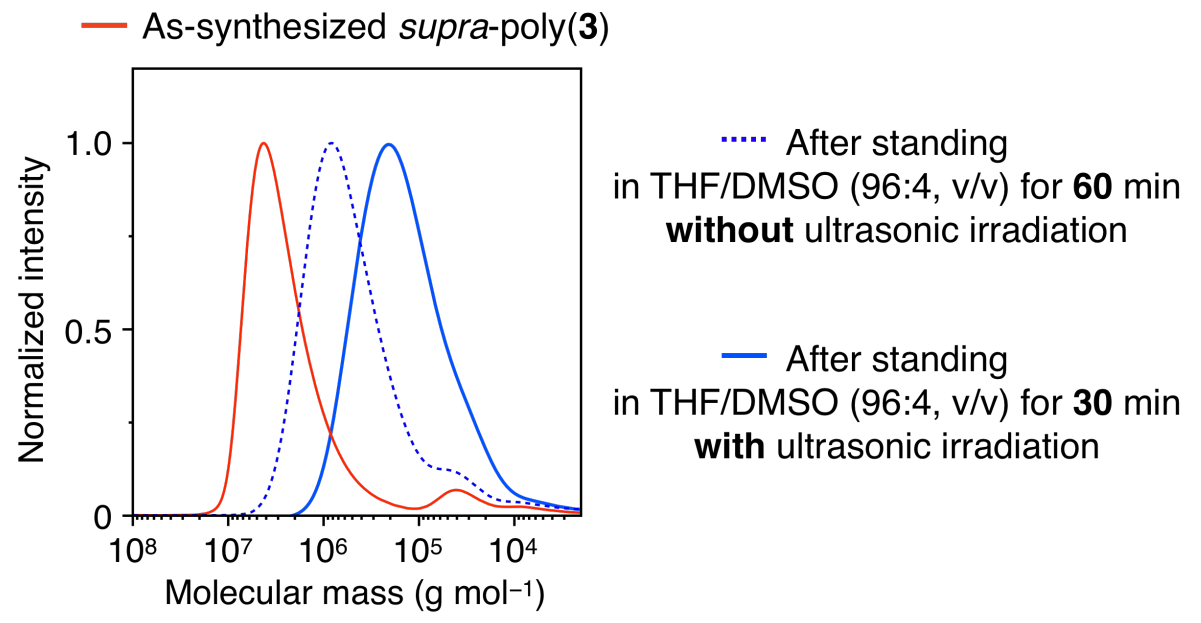

Figure S6. SEC traces of the polymerization product synthesized from the glycine-based isocyanide 3 before and during dissociation. The chromatograms indicated by blue solid and dashed lines were obtained after standing the as-synthesized supra-poly(3) sample in THF/DMSO (96:4, v/v) with and without ultrasonic irradiation for 30 and $60 \mathrm{~min}$, respectively. Result for as-synthesized supra-poly(3) without a dissociation treatment is also shown by a red solid line for comparison.

A: supra-poly(3)
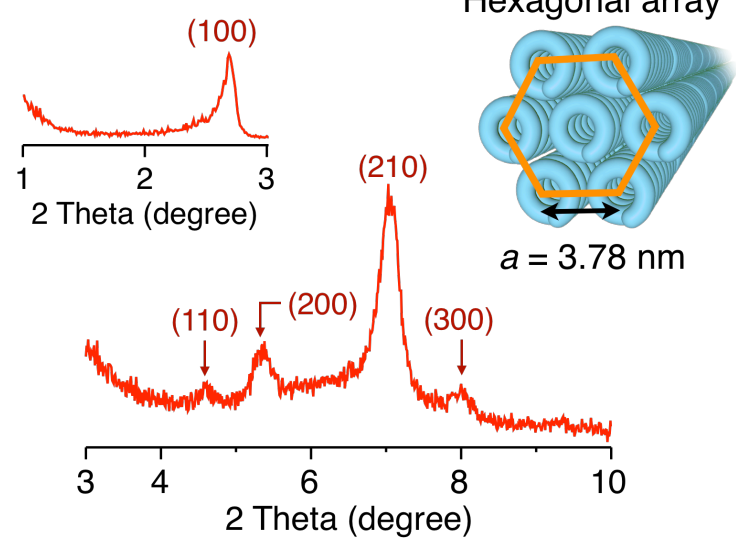

Hexagonal array

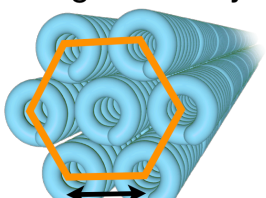

B: Completely dissociated poly(3)

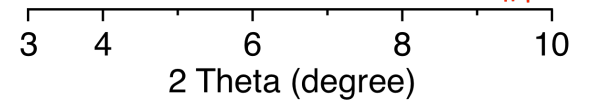

Figure S7. Thin-film XRD patterns of (A) supra-poly(3) and (B) the completely dissociated poly(3). Specimens were prepared by drop-casting of their chloroform solutions $\left(23 \mathrm{mg} \mathrm{mL}^{-1}\right)$. 


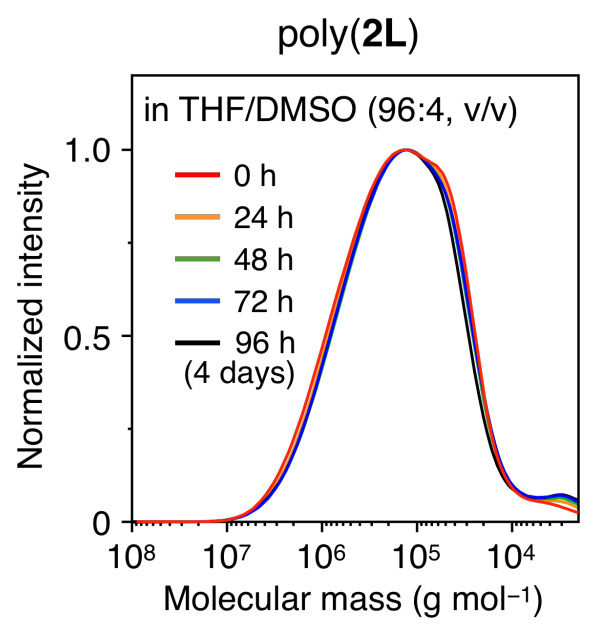

Figure S8. Time-dependent changes in SEC traces of poly $(\mathbf{2} \mathbf{L})$ when keeping the completed reaction system at $25^{\circ} \mathrm{C}$ after diluting 300-fold with THF/DMSO (96:4, v/v).
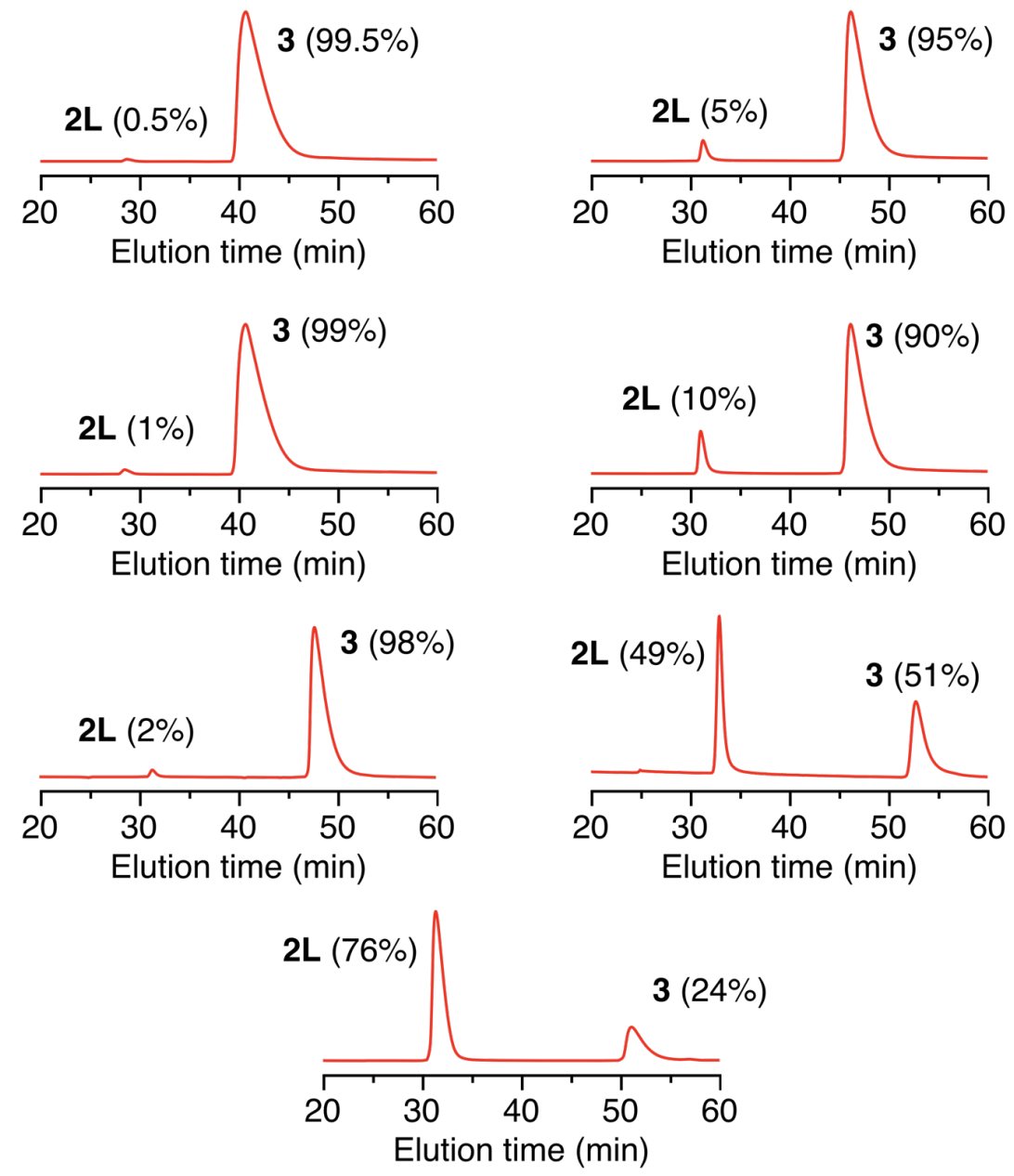

Figure S9. Verification of initial feed ratios of $\mathbf{3}$ and $\mathbf{2 L}$ by HPLC on CHIRALPAK IE-3 column (25 $\mathrm{cm} \times 0.46 \mathrm{~cm}$ (i.d.)) at ca. $20{ }^{\circ} \mathrm{C}$. Chromatograms show UV traces recorded at $254 \mathrm{~nm}$. Eluent, hexane/ethyl acetate $(80: 20, \mathrm{v} / \mathrm{v})$; flow rate, $0.5 \mathrm{~mL} \mathrm{~min}^{-1}$. 


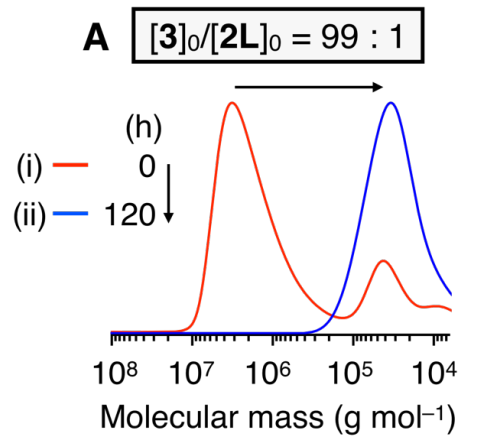
B $[3]_{0} /[2 L]_{0}=90: 10$
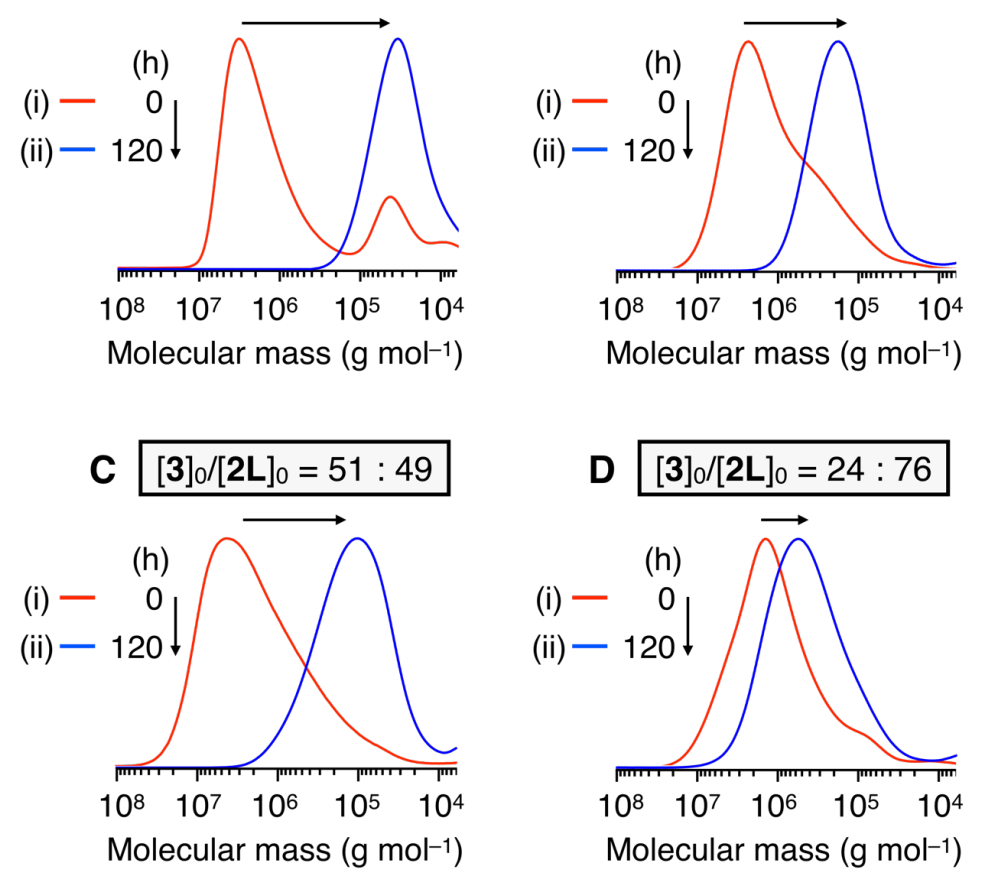

Figure S10. SEC traces of copolymerization products just after diluting the completed copolymerization systems with THF (i; red lines) and after allowing to stand the samples of (i) at $25^{\circ} \mathrm{C}$ for $120 \mathrm{~h}$ (ii; blue lines). [3]0/[2L $]_{0}=99: 1$ (A), 90:10 (B), 51:49 (C), and 24:76 (D).
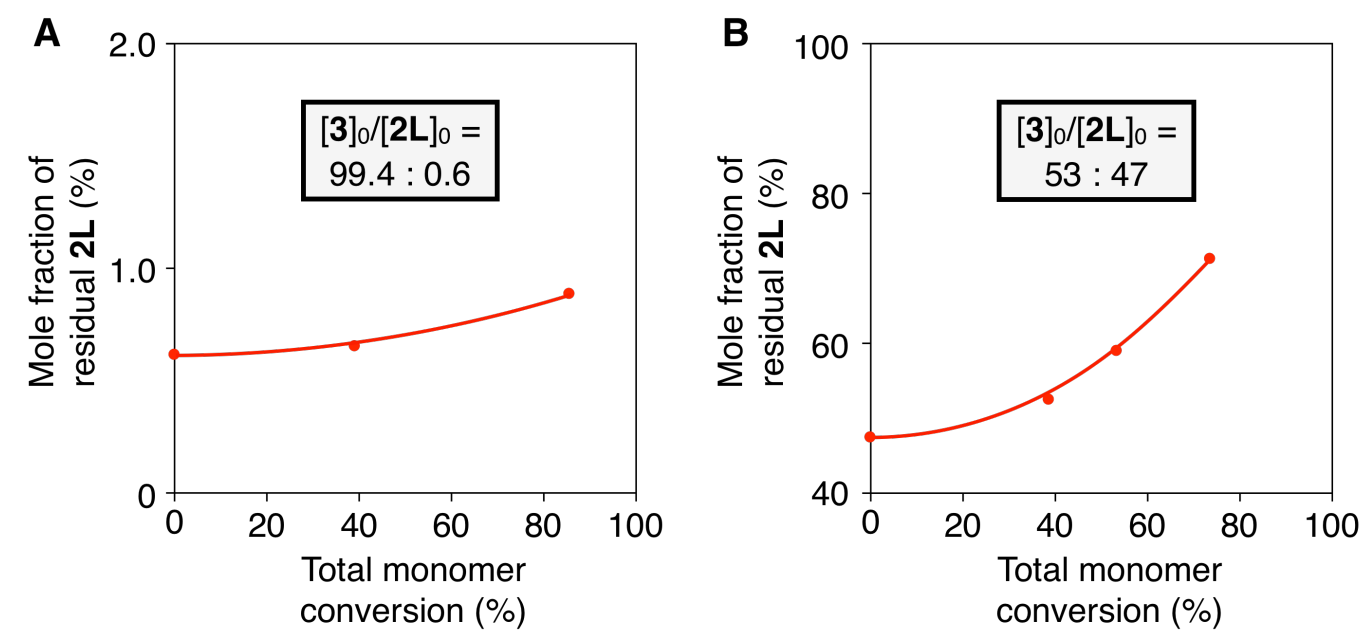

Figure S11. Changes in the mole fraction of residual $2 \mathbf{L}$ during copolymerizations of 3 and $2 \mathbf{L}$. $[3]_{0} /[\mathbf{2 L}]_{0}=99.4: 0.6(\mathrm{~A})$ and 53:47 (B). 


\section{$[3]_{0} /[2 L]_{0}=99: 1$}

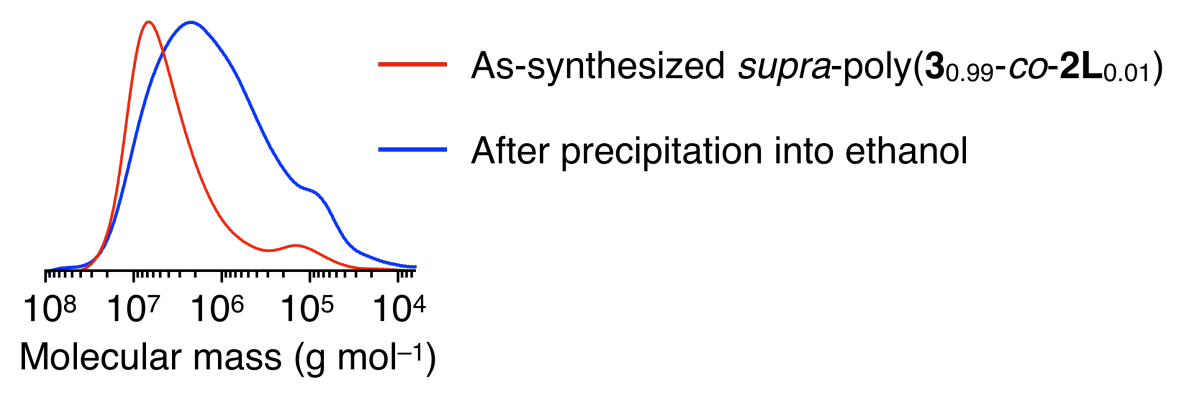

Figure S12. SEC traces of supra-poly $\left(\mathbf{3}_{\left.0.99-c o-2 \mathbf{L}_{0.01}\right)}\right.$ before (red line) and after (blue line) precipitation into ethanol.

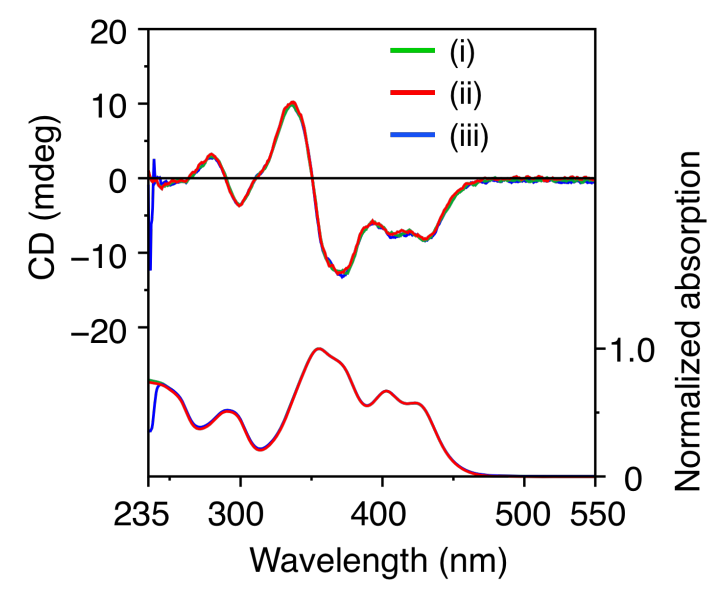

Figure S13. Absorption (lower) and CD (upper) spectra of supra-poly $\left(\mathbf{3}_{0.99-c o-2} \mathbf{L}_{0.01}\right)$ in chloroform at $-10{ }^{\circ} \mathrm{C}$. Spectra indicated by green lines were obtained from the completed copolymerization system diluted ca. 13-fold with chloroform (i). Solutions of (ii; red lines) and (iii; blue lines) were prepared by accurately diluting above sample (i) 10- and 100-fold with chloroform, respectively. Spectral measurements of (i), (ii), and (iii) were performed with cell path lengths of 0.10, 1.0, and $10 \mathrm{~mm}$, respectively. 

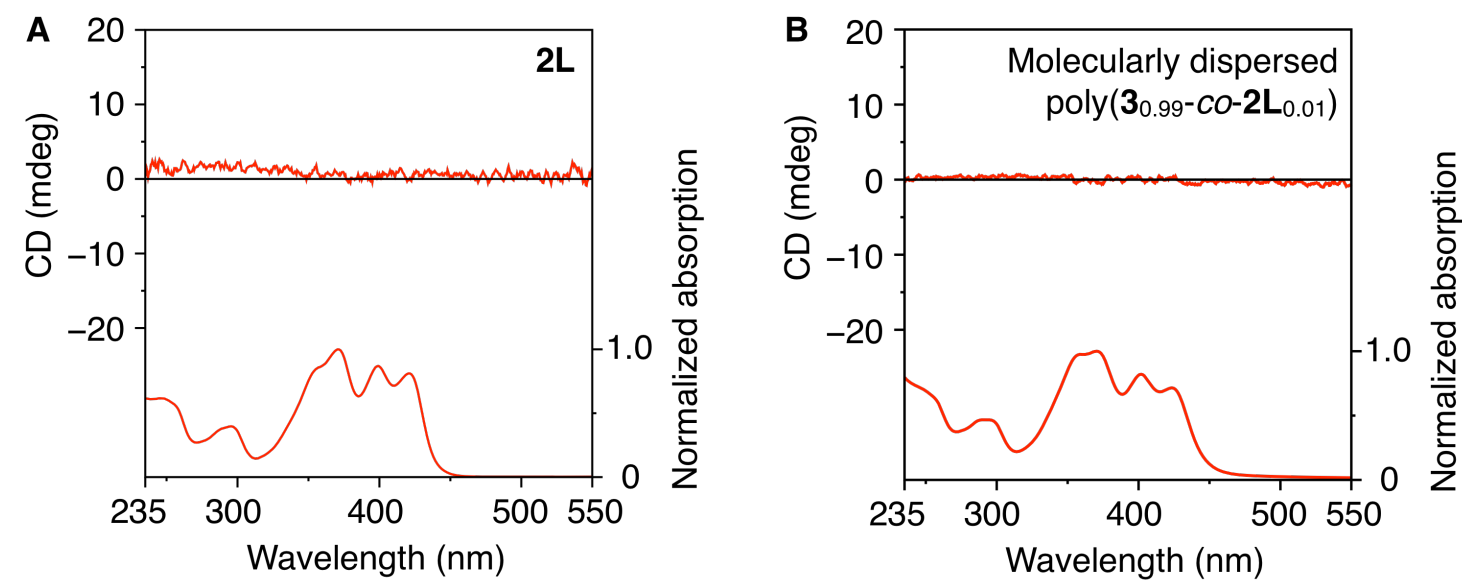

Figure S14. Absorption (lower) and CD (upper) spectra of (A) 2L monomer and (B) molecularly dispersed poly $\left(\mathbf{3}_{0.99}-\mathrm{co}-\mathbf{2} \mathbf{L}_{0.01}\right)$ in chloroform at $-10^{\circ} \mathrm{C}$. $[\mathbf{2} \mathbf{L}$ or repeating unit $]=1.0 \times 10^{-4} \mathrm{M}$.
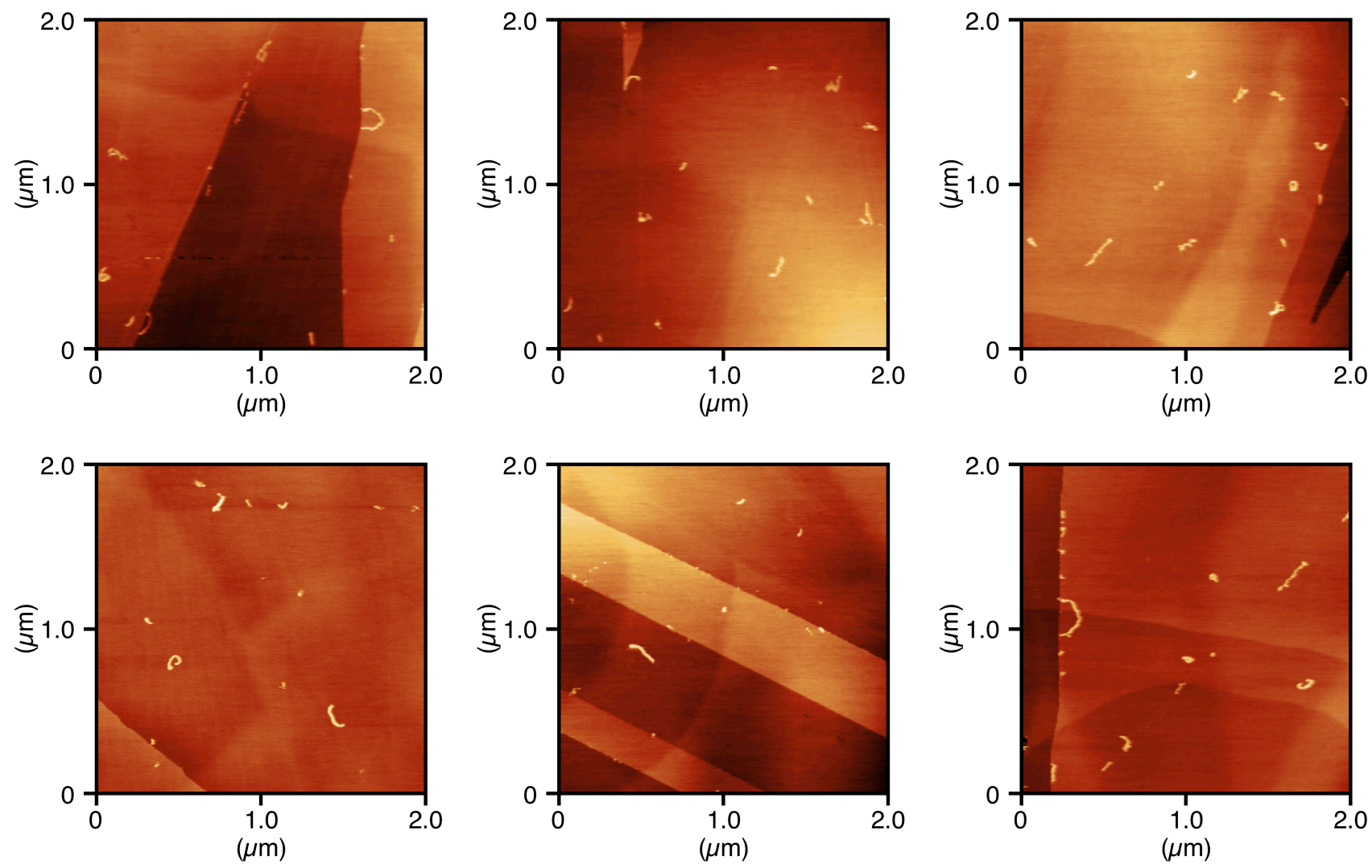

Figure S15. AFM images $\left(2.0 \times 2.0 \mu \mathrm{m}^{2}\right)$ of supra-poly $\left(\mathbf{3}_{\left.0.99-c o-2 \mathbf{L}_{0.01}\right)}\right.$ on HOPG in air at ca. $20{ }^{\circ} \mathrm{C}$. A specimen was prepared by spin-casting the reaction system diluted with chloroform after polymerization was complete. 


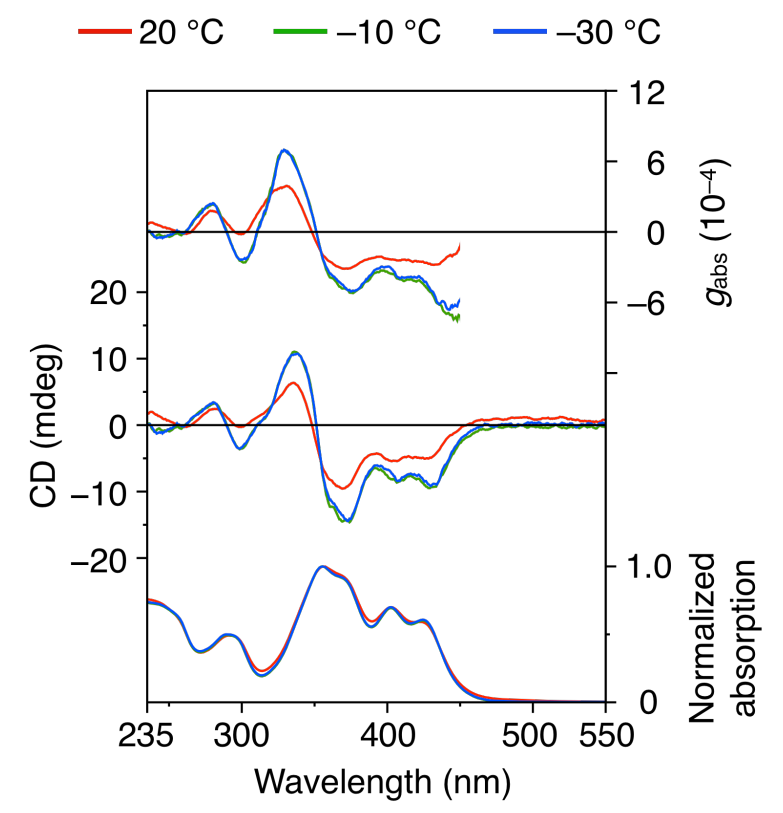

Figure S16. Absorption (bottom), CD (middle), and $g_{\text {abs }}$ (top) spectra of supra-poly(30.99-co-2 $\mathbf{L}_{0.01}$ ) obtained through polymerizations in chloroform at different temperatures. The $g_{\text {abs }}$ value, which can be interpreted as the CD intensity per molar absorption coefficient, was used for chiroptical comparison because controlling the solution concentration precisely was difficult and a molar circular dichroism could not be obtained.

(i) - As-synthesized supra-poly $\left(\mathbf{3}_{0.99}-c 0-2 \mathbf{L}_{0.01}\right)$

(ii) - After standing in chloroform at $-10^{\circ} \mathrm{C}$ for $72 \mathrm{~h}$

(iii) — After standing in chloroform at $25^{\circ} \mathrm{C}$ for $72 \mathrm{~h}$
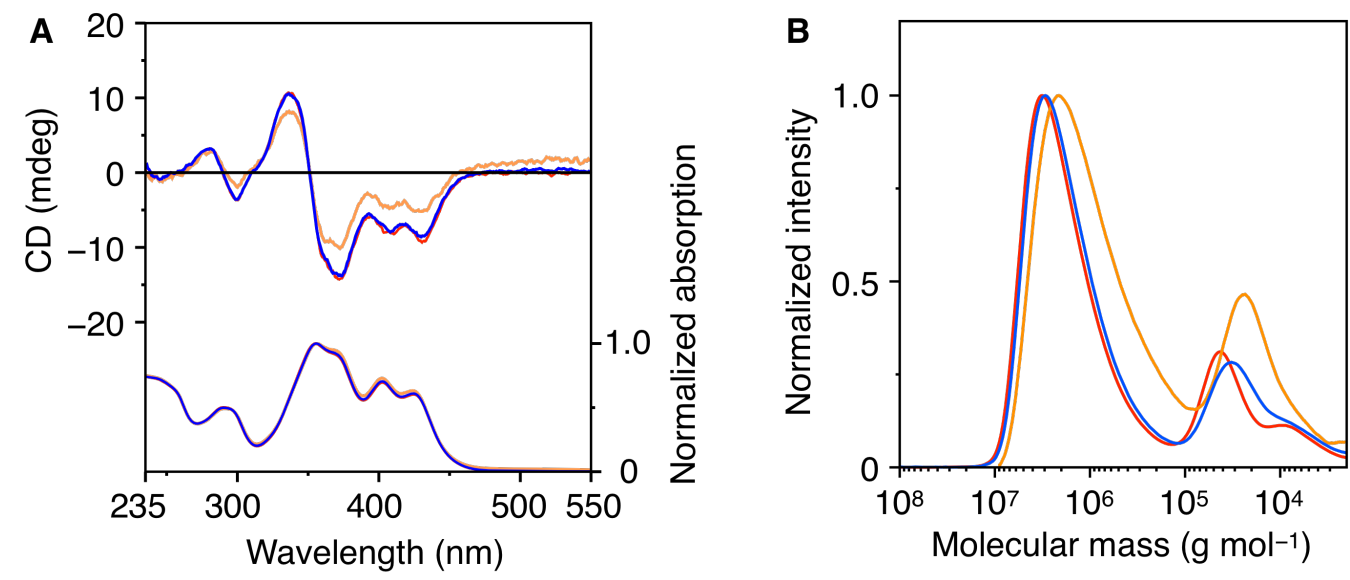

Figure S17. (A) Absorption/CD spectra and (B) SEC traces of supra-poly $\left(\mathbf{3}_{0.99-c o-2} \mathbf{L}_{0.01}\right)$ in chloroform measured at $-10{ }^{\circ} \mathrm{C}$ just after diluting the completed reaction system with chloroform (300-fold) (i; red lines) and after allowing to stand the samples of (i) at $-10{ }^{\circ} \mathrm{C}$ (ii; blue lines) and $25^{\circ} \mathrm{C}$ (iii; yellow lines) for $72 \mathrm{~h}$. 


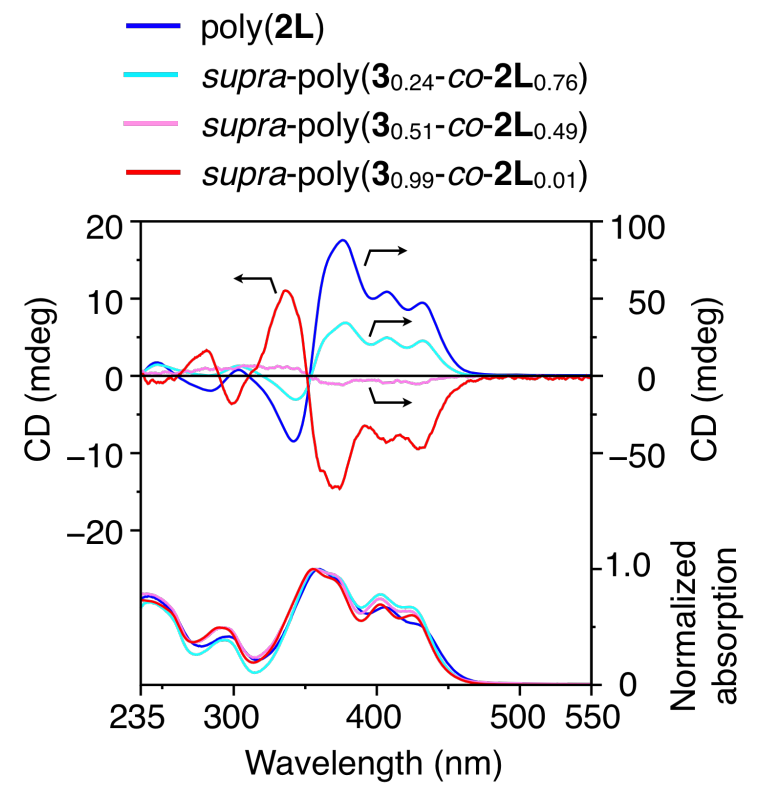

Figure S18. Absorption (lower) and CD (upper) spectra of poly(2L), supra-poly $\left(\mathbf{3}_{0.24-c o-2} \mathbf{L}_{0.76}\right)$,

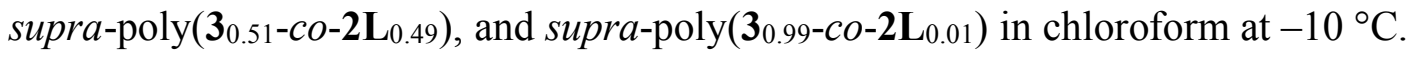

$$
\begin{aligned}
r=0.01 \\
r=0.005 \\
r=0.002 \\
r=0.001 \\
r=0.0001
\end{aligned}
$$

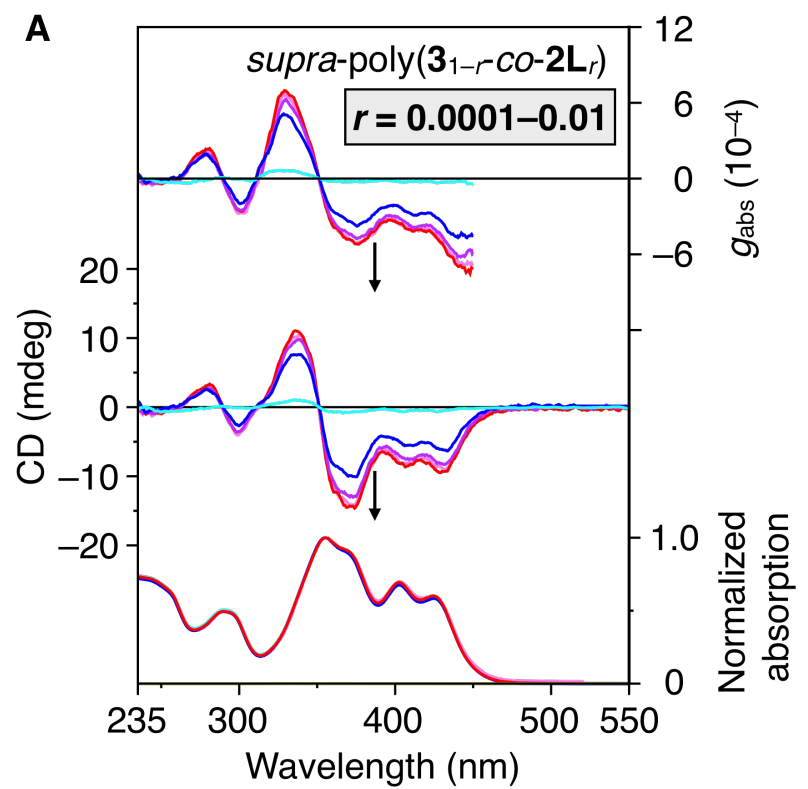

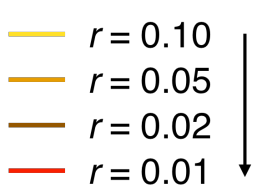

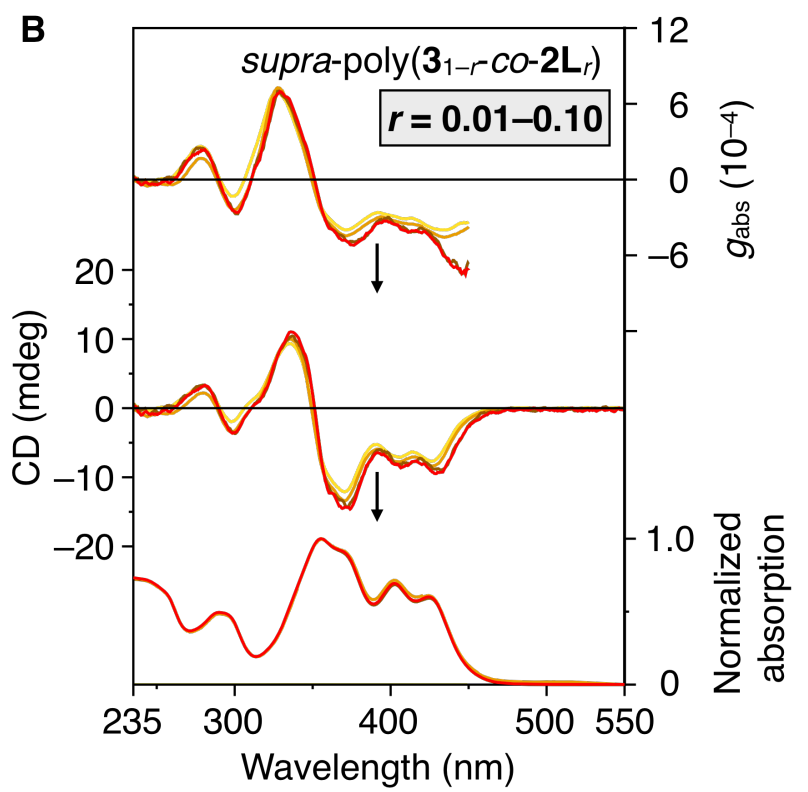

Figure S19. Absorption (bottom), CD (middle), and $g_{\text {abs }}$ (top) spectra of supra-poly(3 $\left.\mathbf{3}_{1-r}-c o-2 \mathbf{L}_{r}\right)(r=$ $0.0001-0.01(\mathrm{~A})$ and $0.01-0.10(\mathrm{~B}))$ in chloroform at $-10^{\circ} \mathrm{C}$. 
A: supra-poly(30.99-co-2 $\left.\mathbf{L}_{0.01}\right)$

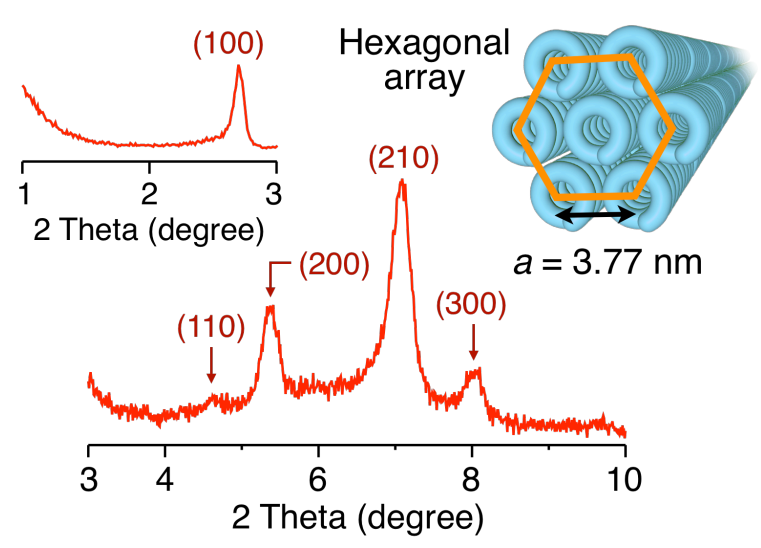

B: supra-poly $\left(\mathbf{3}_{0.99-}-\mathrm{co}_{-2} \mathbf{L}_{0.01}\right) / \mathrm{Cy3}$

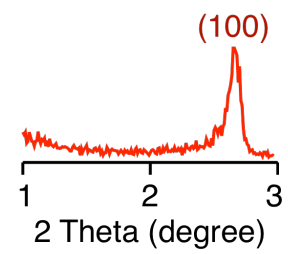

Hexagonal array

(210)

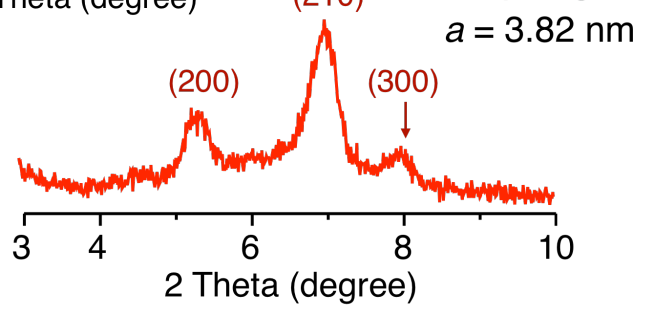

C: poly(2L)

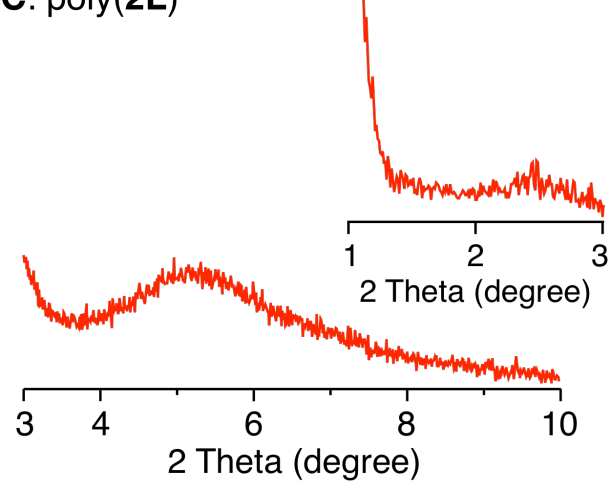

Figure S20. Thin-film XRD patterns of supra-poly $\left(\mathbf{3}_{0.99-}-c o-2 \mathbf{L}_{0.01}\right)$ in the (A) absence and (B) presence of $\mathrm{Cy} 3$ (polymer/dye $=6: 4, \mathrm{w} / \mathrm{w}$ ) and $(\mathrm{C})$ poly $(\mathbf{2} \mathbf{L})$. Specimens were prepared through drop-casting of their chloroform solutions $\left(23 \mathrm{mg} \mathrm{mL}^{-1}\right)$. 


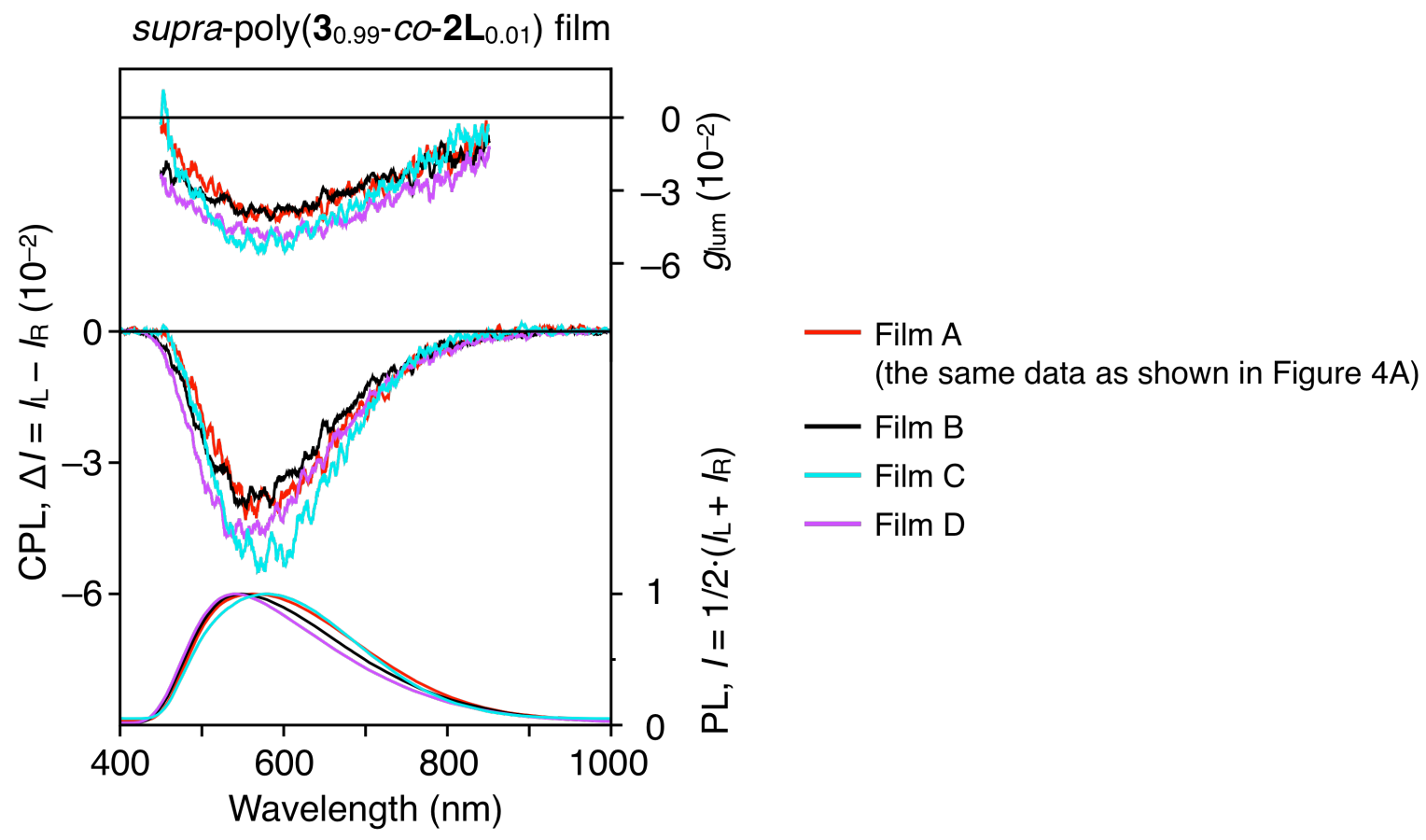

Figure S21. Verification of the repeatability of the CPL performance. PL (bottom), CPL (middle), and $g_{\text {lum }}$ (top) spectra of the four independently prepared supra-poly $\left(\mathbf{3}_{0.99}-c o-2 \mathbf{L}_{0.01}\right)$ films (A-D) at room temperature (ca. $20^{\circ} \mathrm{C}$ ); $\lambda_{\mathrm{ex}}=350 \mathrm{~nm}$. The results of film A are the same as the red lines in Figure 4A.

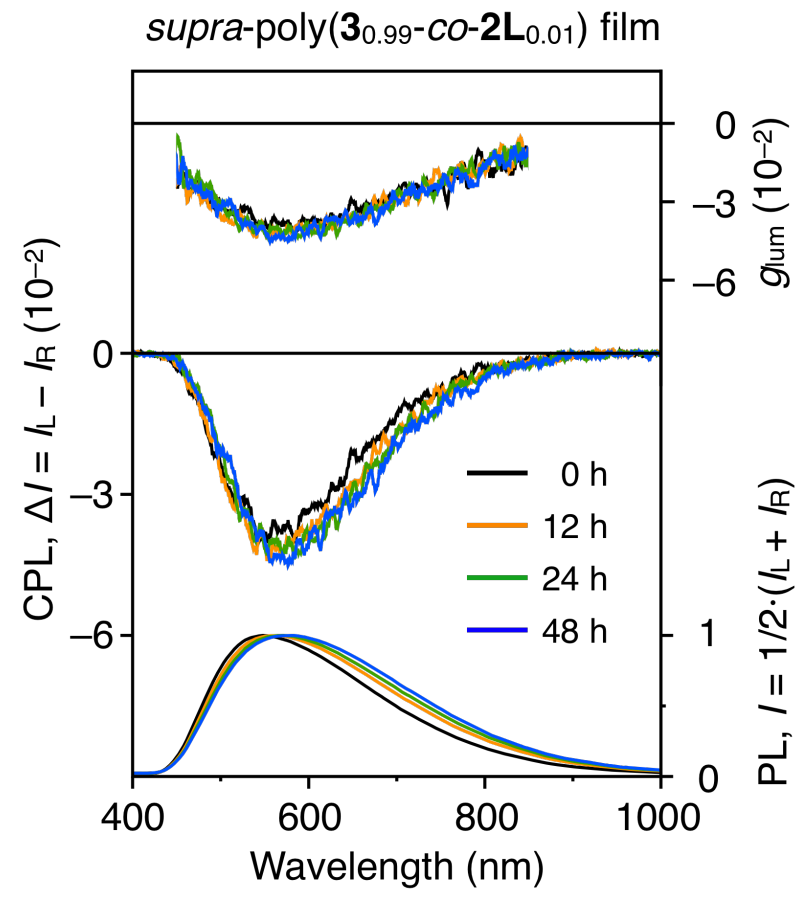

Figure S22. Verification of the stability of the CPL performance. PL (bottom), CPL (middle), and $g_{\text {lum }}$ (top) spectra of the supra-poly $\left(\mathbf{3}_{0.99-c o-2} \mathbf{L}_{0.01}\right)$ film (same as film B in Figure S21) before and after allowing to stand at $25{ }^{\circ} \mathrm{C}$ for 12,24 , and $48 \mathrm{~h}$ measured at room temperature (ca. $20{ }^{\circ} \mathrm{C}$ ); $\lambda_{\mathrm{ex}}=350$ $\mathrm{nm}$. 


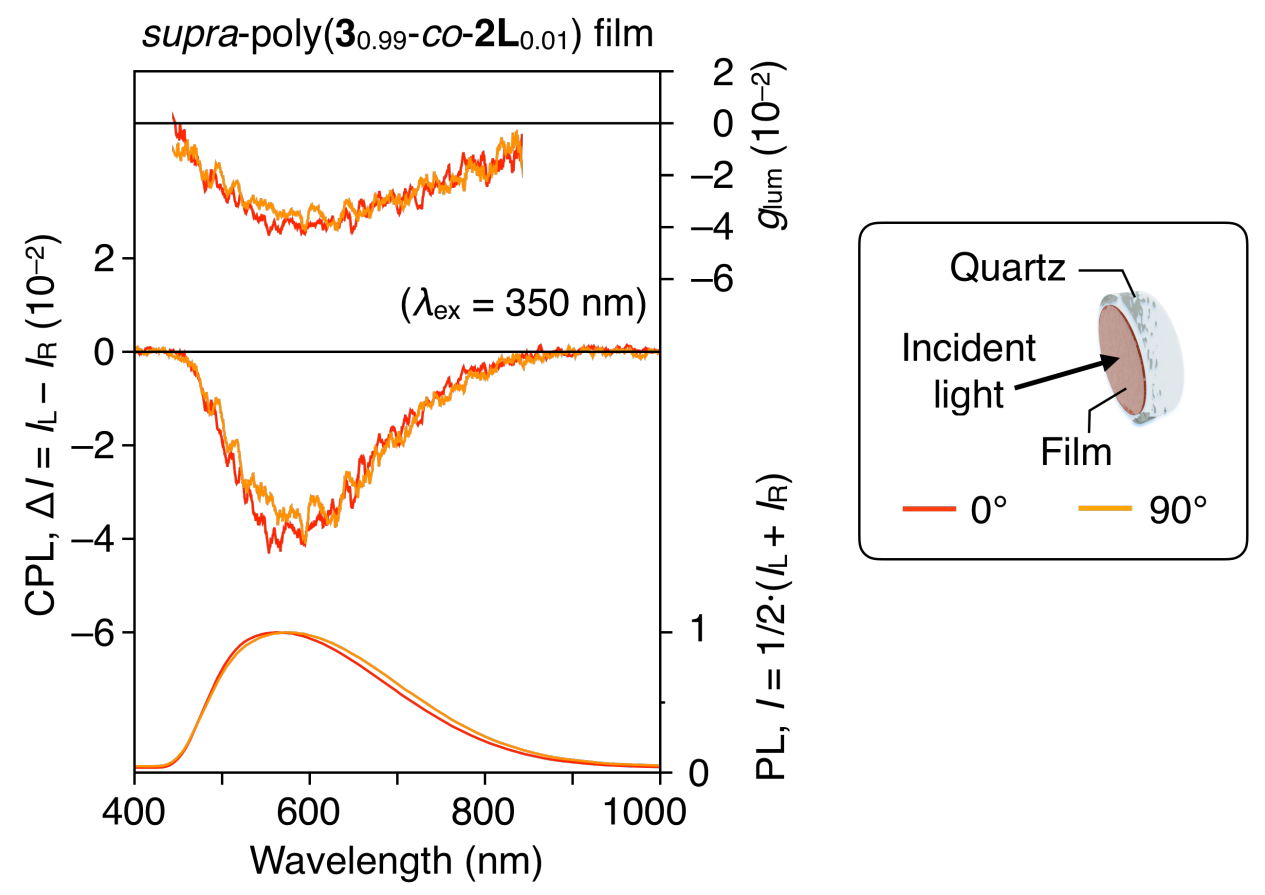

Figure S23. PL (bottom), CPL (middle), and $g_{\text {lum }}$ (top) spectra of the drop-cast film of supra-poly $\left(\mathbf{3}_{0.99-c o-2} \mathbf{L}_{0.01}\right)$ at room temperature. Spectra were measured at different rotation angles.

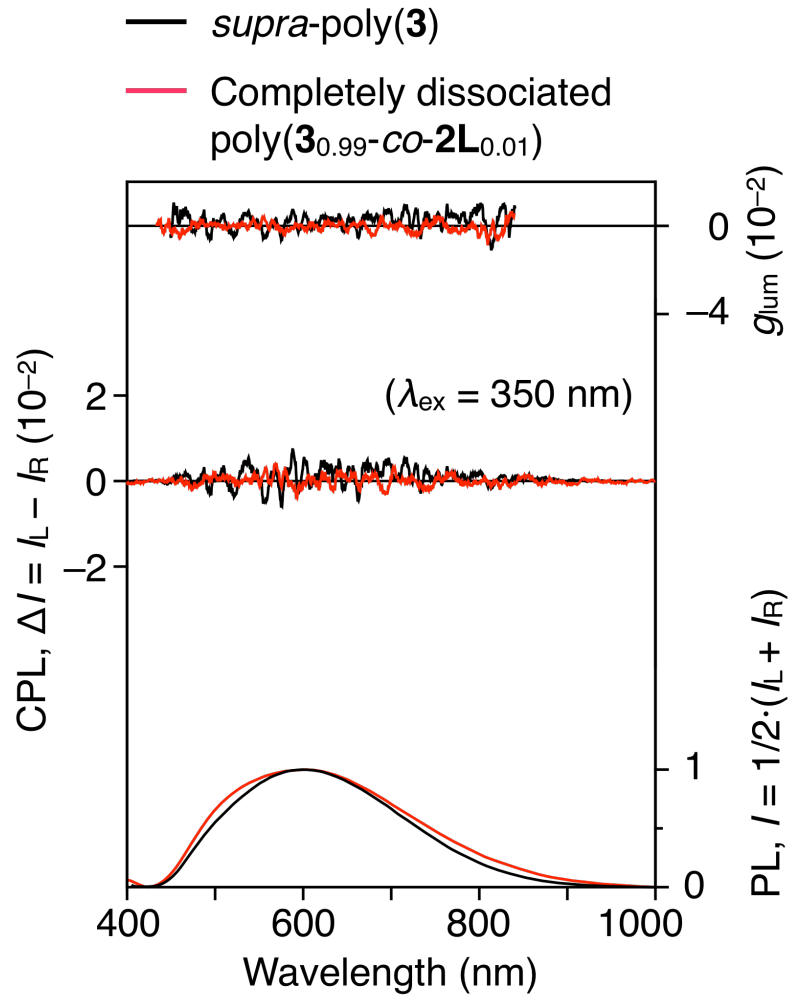

Figure S24. PL (bottom), CPL (middle), and $g_{\text {lum }}$ (top) spectra of the drop-cast films of supra-poly(3) (black lines) and completely dissociated poly $\left(\mathbf{3}_{0.99-c o-2} \mathbf{L}_{0.01}\right)$ (red lines) at room temperature. 


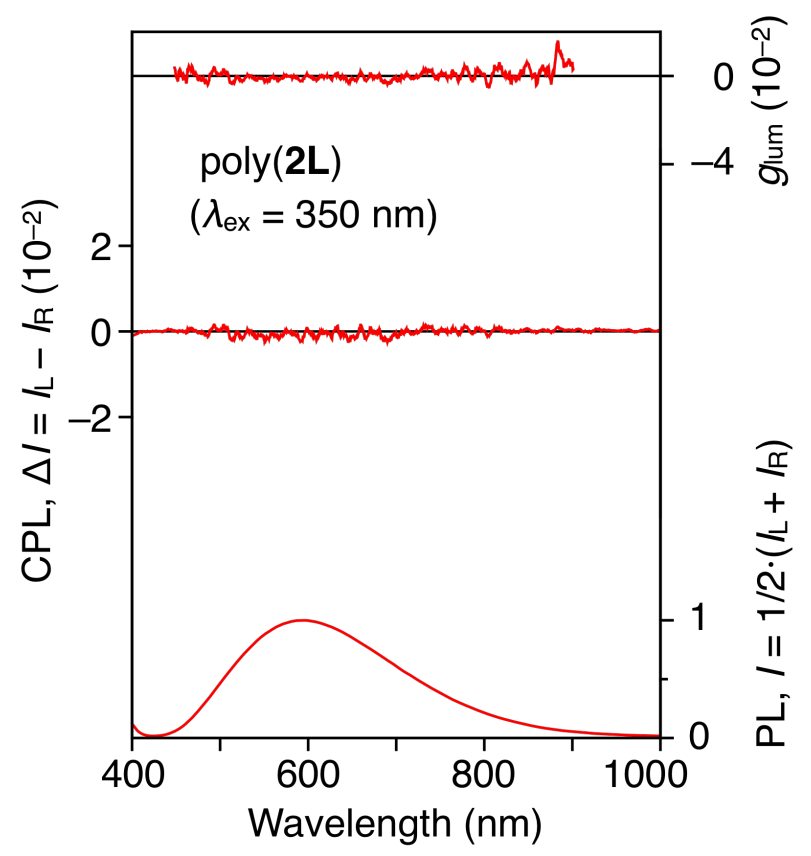

Figure S25. PL (bottom), CPL (middle), and $g_{\text {lum }}$ (top) spectra of the drop-cast film of poly(2L) at room temperature.

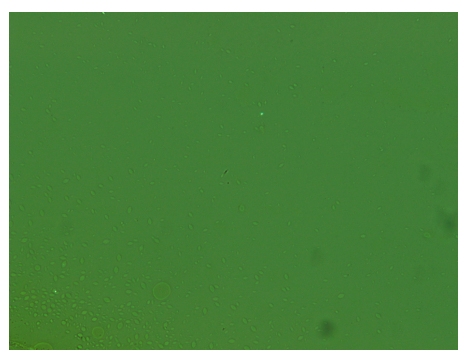

Figure S26. Polarized optical micrograph of an isotropic phase of poly(2L) in a maximally concentrated chloroform solution (ca. $11 \mathrm{wt} \%$ ) taken at room temperature (ca. $20^{\circ} \mathrm{C}$ ). 


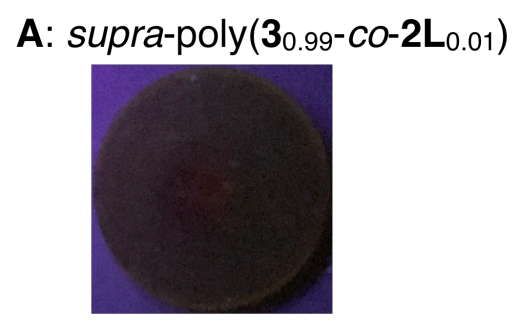

\section{B: 3}

C: $\mathbf{2 L}$
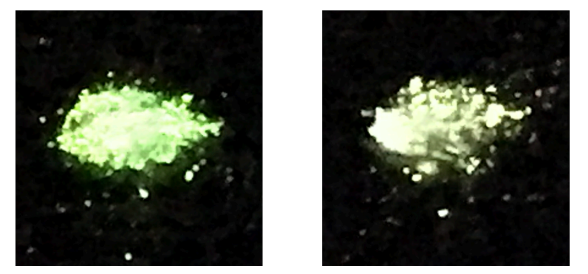

Figure S27. Photographs of (A) the drop-cast film of supra-poly $\left(\mathbf{3}_{0.99}-c o-2 \mathbf{L}_{0.01}\right)$, and (B) $\mathbf{3}$ and (C) $\mathbf{2} \mathbf{L}$ in the powdered state under irradiation at $365 \mathrm{~nm}$.

\begin{tabular}{|c|c|c|}
\hline \multirow[t]{2}{*}{ supra-poly(3) } & & \multirow{3}{*}{$\begin{array}{l}\text { Chiroptical } \\
\text { measurement }\end{array}$} \\
\hline & 1. IVIIXing al valiuns milual latius & \\
\hline supra-poly $\left(\mathbf{3}_{0.99}-c 0-2 \mathbf{L}_{0.01}\right)$ & $\begin{array}{l}\text { 2. Stirring at }-10^{\circ} \mathrm{C} \text { for } 1 \mathrm{~h} \\
\text { 3. Diluting with chloroform }\end{array}$ & \\
\hline
\end{tabular}

A

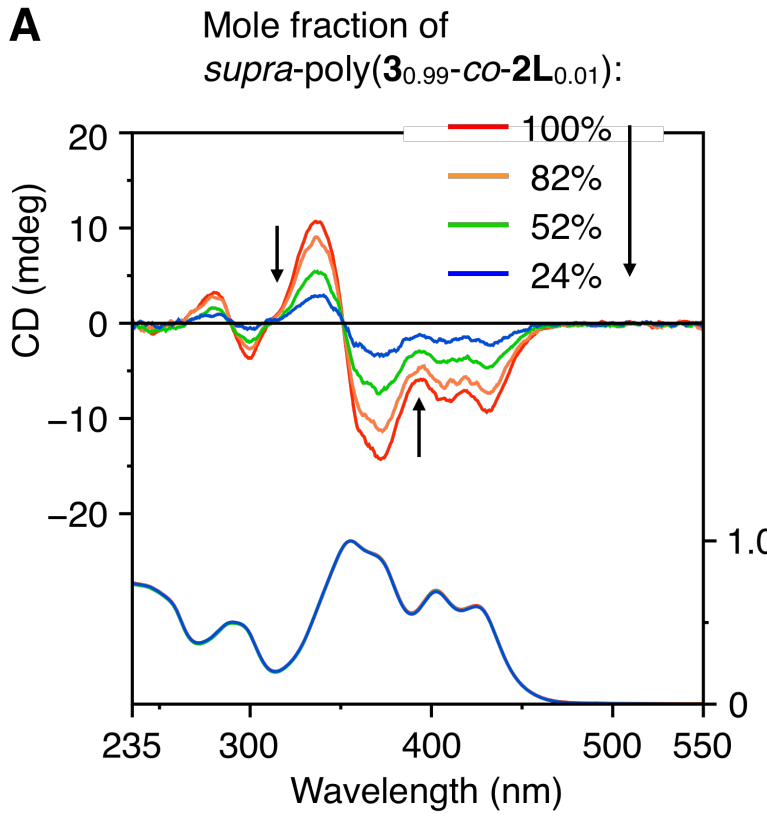

B

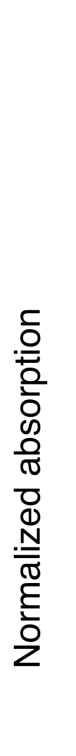

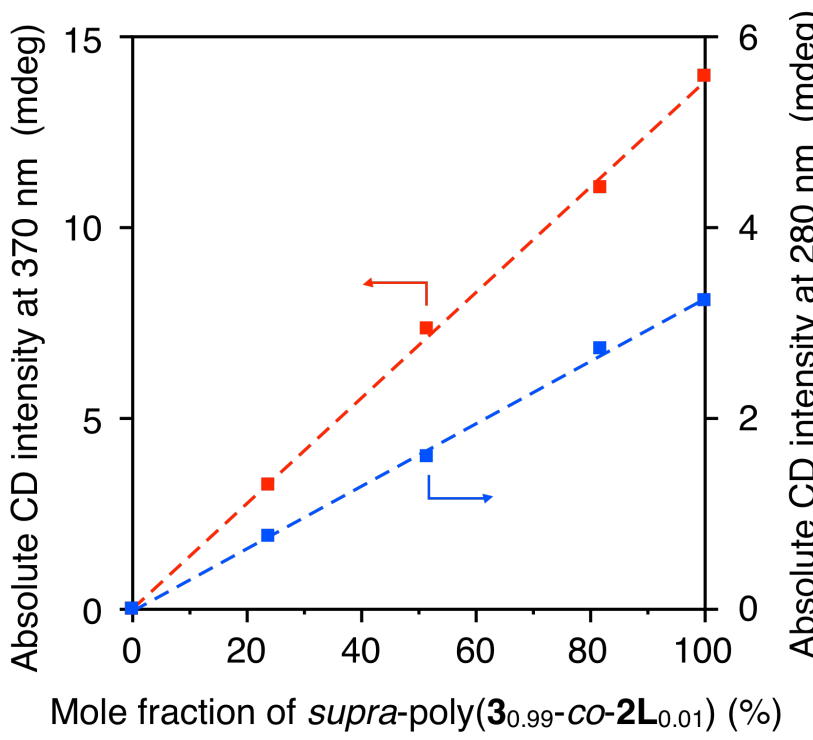

Mole fraction of supra-poly $\left(\mathbf{3}_{0.99}-\mathrm{co}-\mathbf{2} \mathbf{L}_{0.01}\right)(\%)$

Figure S28. (A) Absorption (lower) and CD (upper) spectra of supra-poly $\left(\mathbf{3}_{0.99-c o-2} \mathbf{L}_{0.01}\right) /$ supra-poly(3) mixtures in chloroform at $-10{ }^{\circ} \mathrm{C}$. Samples were prepared by mixing the completed two polymerization systems at various molar ratios, stirring for $1 \mathrm{~h}$ at $-10{ }^{\circ} \mathrm{C}$, and diluting with chloroform, as shown at the top of the figure. Molar ratios were calculated based on the monomeric units. (B) Plots of CD intensities at $370 \mathrm{~nm}$ (red squares, left-hand vertical axis) and $280 \mathrm{~nm}$ (blue squares, right-hand vertical axis) against the mole fraction of supra-poly $\left(\mathbf{3}_{0.99-c o-2} \mathbf{L}_{0.01}\right)$. 

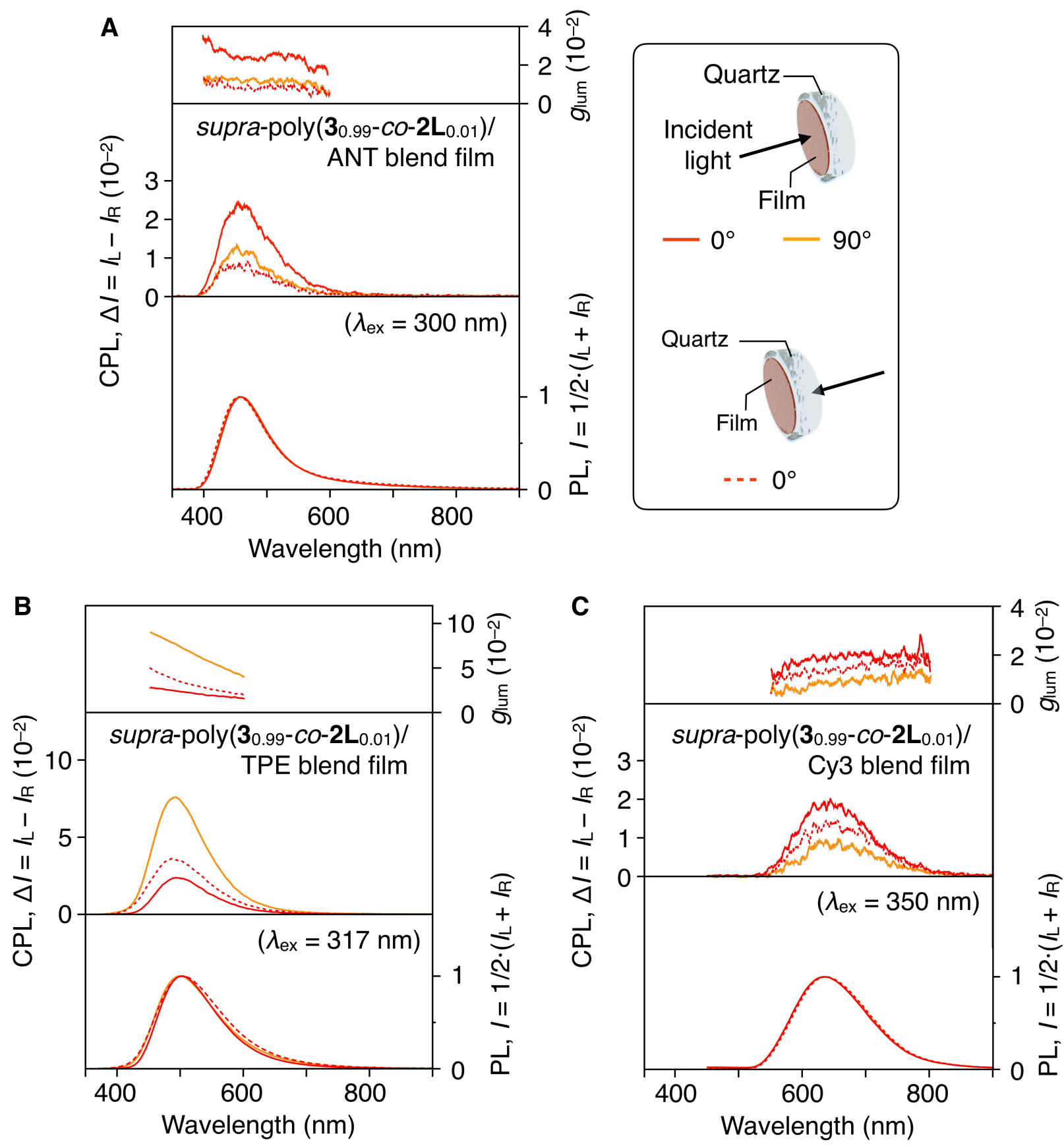

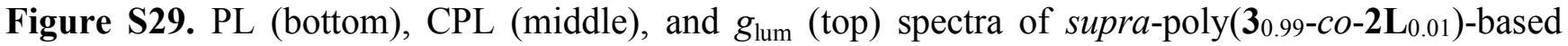
blend films containing (A) ANT (polymer/dye = 7:3, w/w), (B) TPE (polymer/dye =6:4, w/w), and (C) Cy3 (polymer/dye $=6: 4, \mathrm{w} / \mathrm{w})$ at room temperature. Spectra were measured at different rotation angles (red and orange solid lines) and by reversing the quartz plate to an incident light/quartz/film arrangement (red dashed lines). 
A - supra-poly(30.99-co-2 $\left.\mathbf{L}_{0.01}\right) / \mathrm{ANT}$

- - supra-poly(3 $\left.\mathbf{3}_{0.99}-c 0-2 \mathbf{D}_{0.01}\right) / A N T$

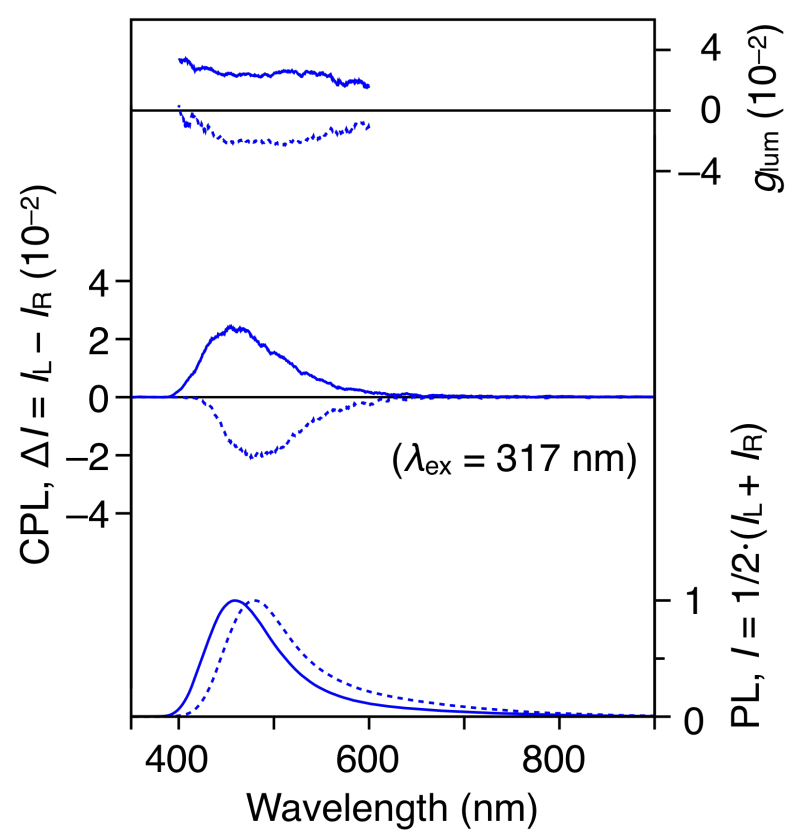

B - supra-poly $\left(\mathbf{3}_{0.99}-c 0-2 \mathbf{L}_{0.01}\right) / \mathrm{TPE}$

- - - supra-poly $\left(\mathbf{3}_{0.99}-\right.$ co-2D 0.01$) / \mathrm{TPE}$

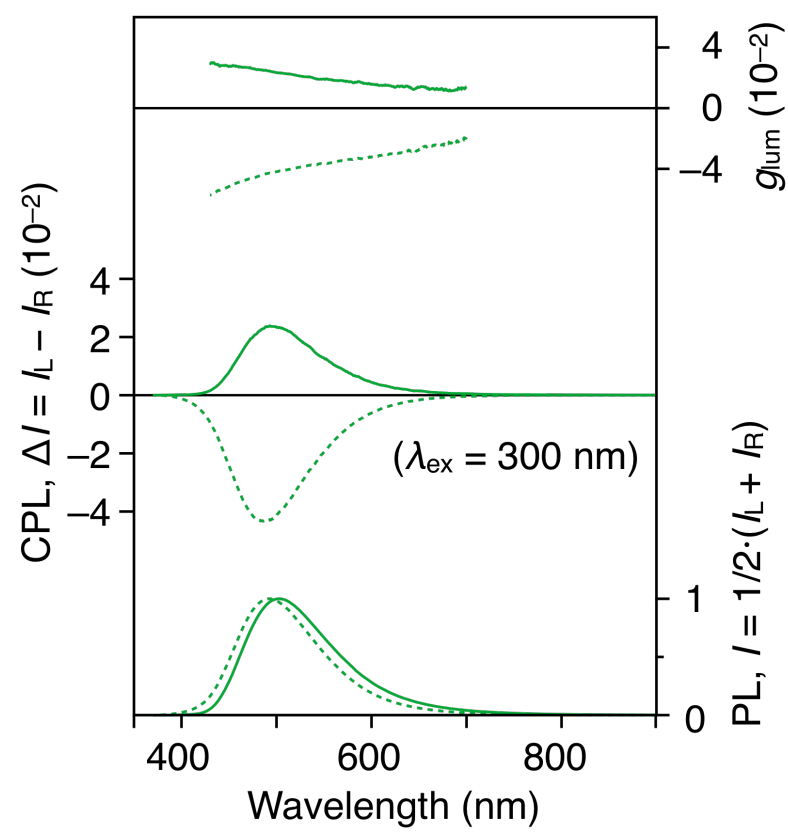

C - supra-poly $\left(\mathbf{3}_{0.99}-\right.$ co-2 $\left._{0.01}\right) /$ Cy3

- - - supra-poly $\left(\mathbf{3}_{0.99}-\right.$ co-2D $\left._{0.01}\right) /$ Cy3

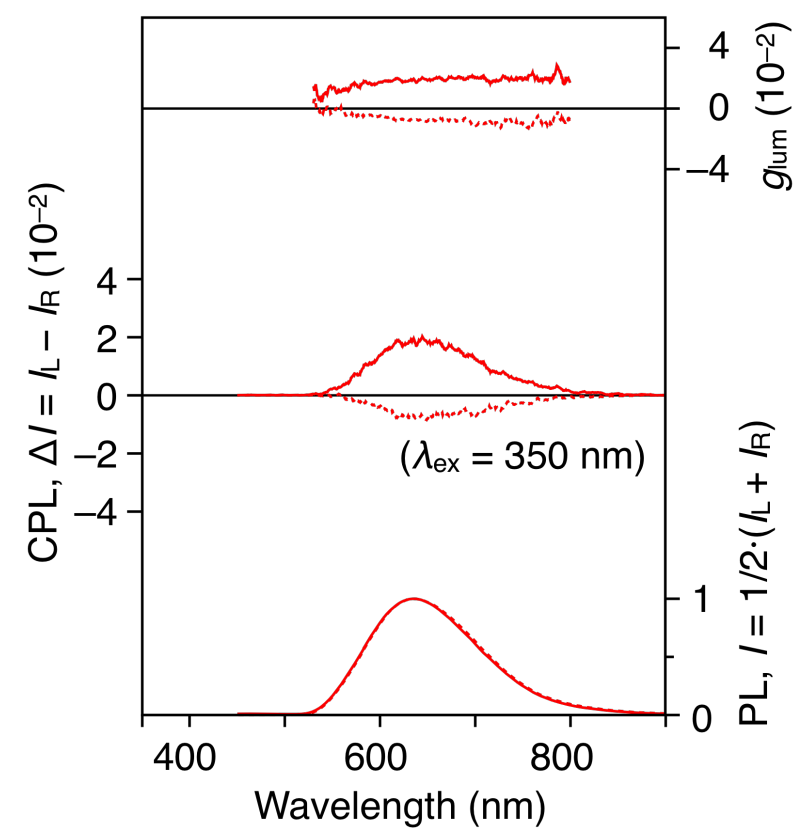

Figure S30. PL (bottom), CPL (middle), and glum (top) spectra of blend films based on

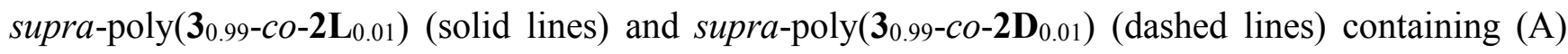
ANT $($ polymer/dye $=7: 3, \mathrm{w} / \mathrm{w}),(\mathrm{B})$ TPE $($ polymer $/$ dye $=6: 4, \mathrm{w} / \mathrm{w})$, and $(\mathrm{C})$ Cy3 $($ polymer/dye $=6: 4$, $\mathrm{w} / \mathrm{w})$ at room temperature. 


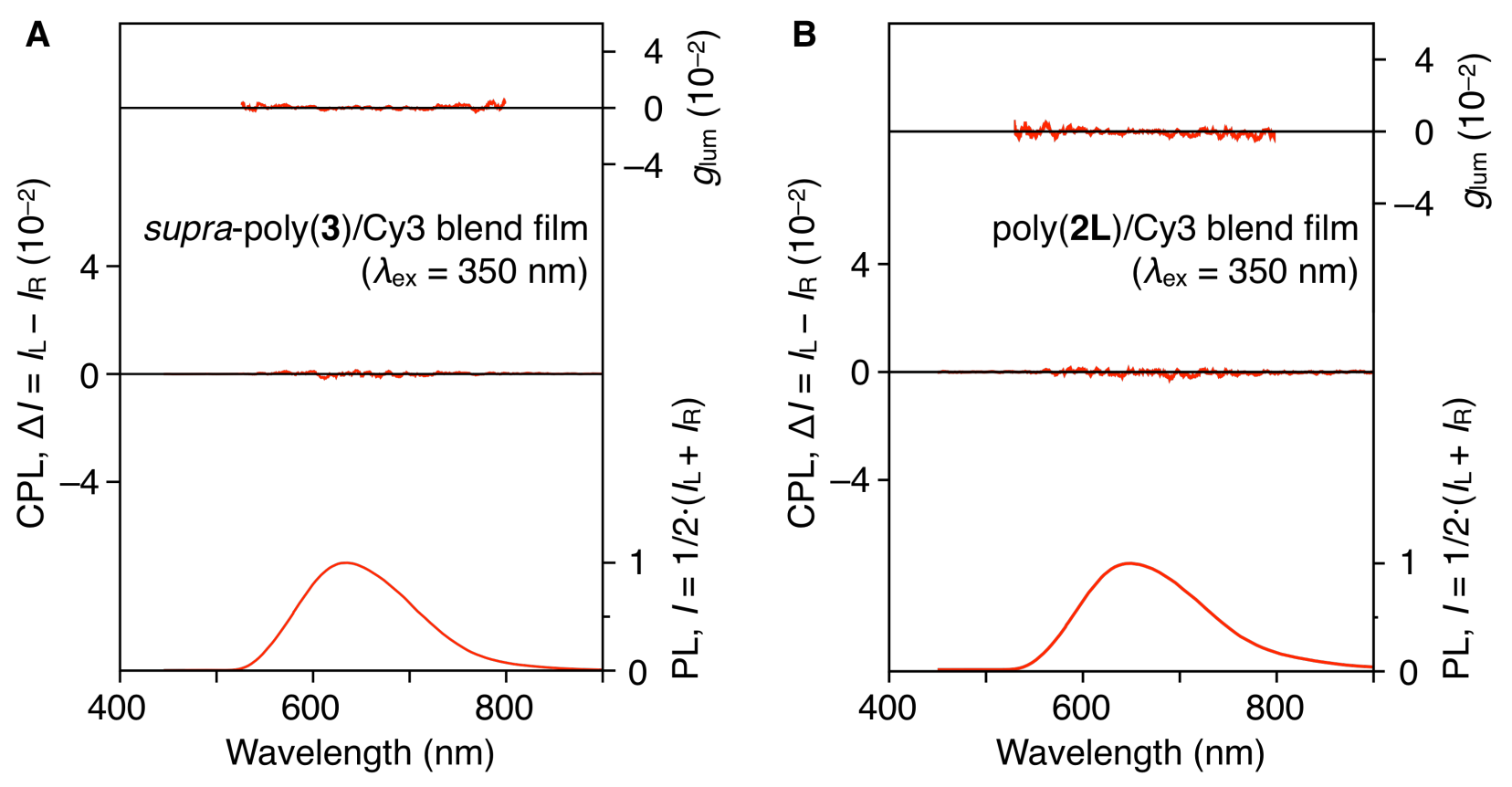

Figure S31. PL (bottom), CPL (middle), and $g_{\text {lum }}$ (top) spectra of (A) supra-poly(3)/Cy3 (6:4, w/w) and (B) poly(2L)/Cy3 (6:4, w/w) blend films at room temperature.
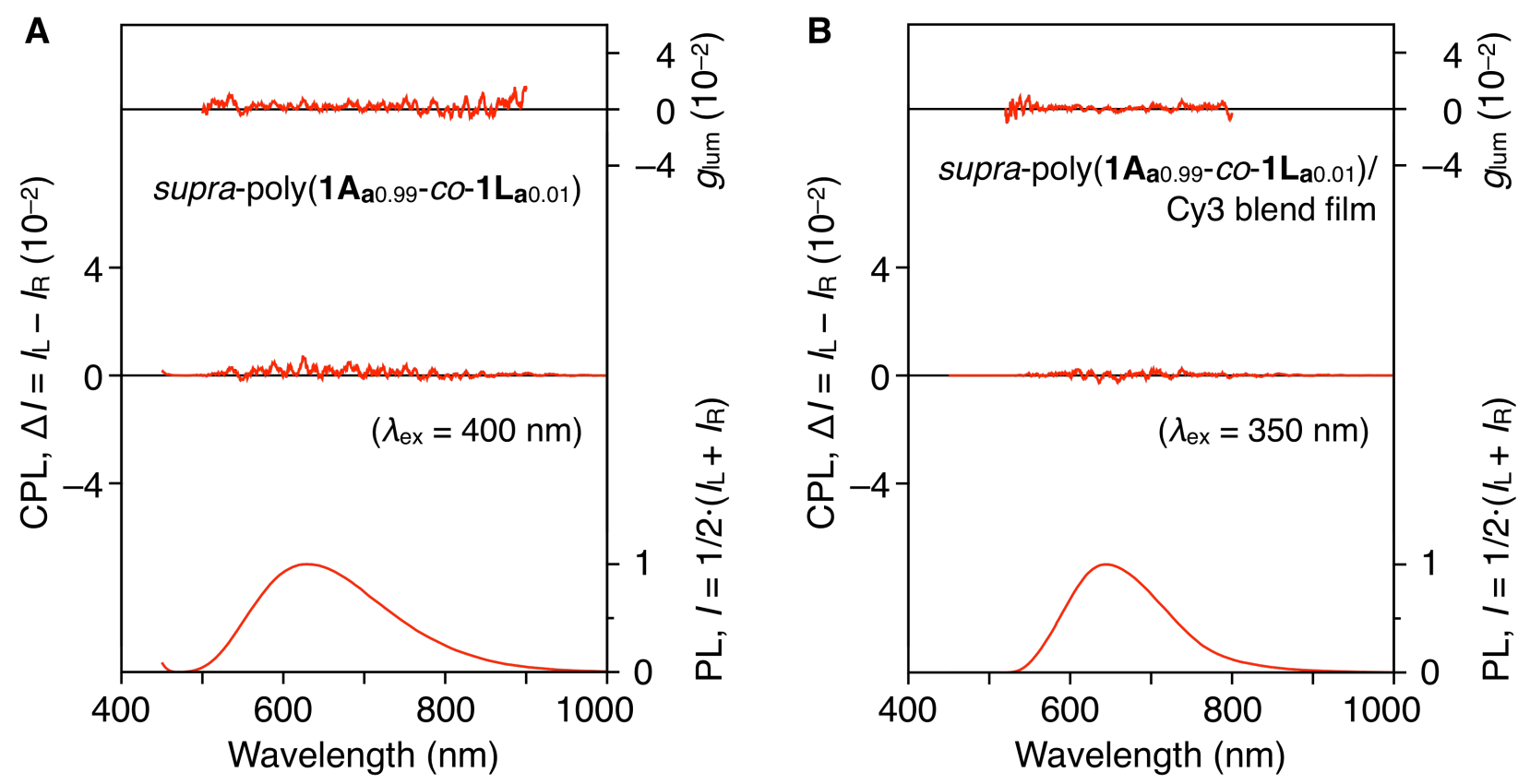

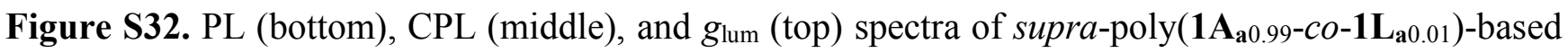
films (A) without and (B) with Cy3 (polymer/dye =6:4, w/w) at room temperature. 
NMR spectral data

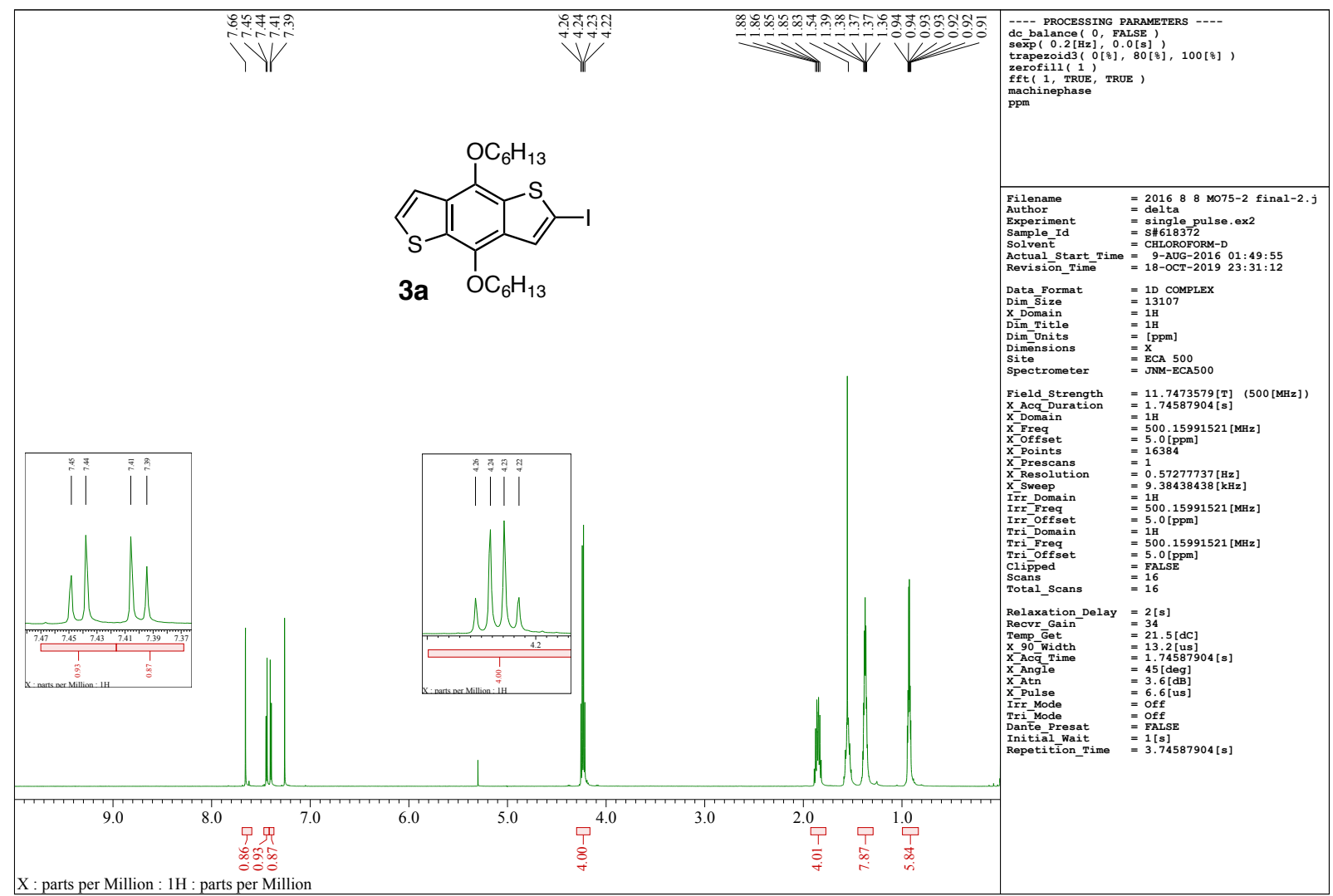

Figure S33. ${ }^{1} \mathrm{H}$ NMR $\left(500 \mathrm{MHz}, \mathrm{CDCl}_{3}\right.$, rt) spectrum of 3a.

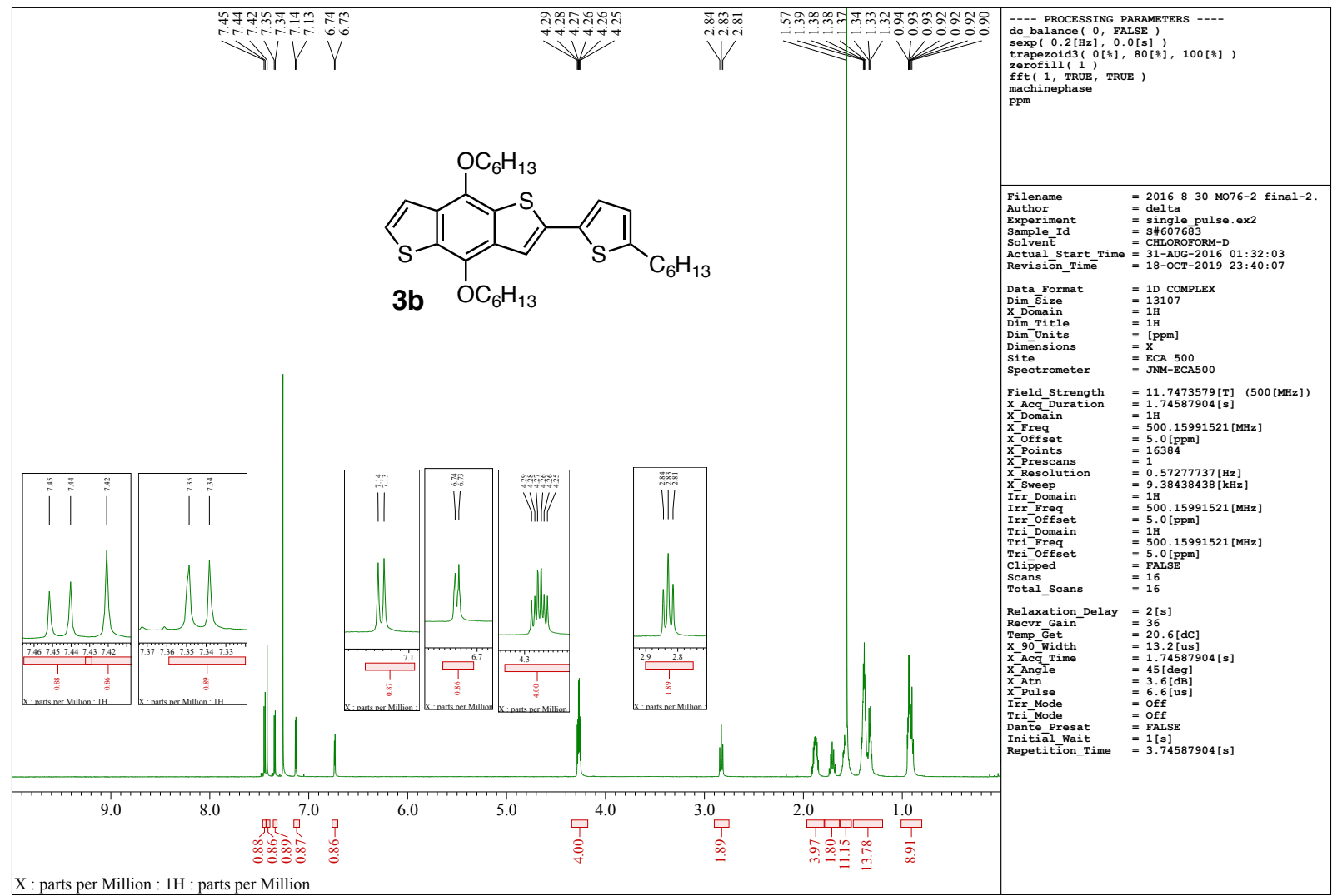

Figure S34. ${ }^{1} \mathrm{H}$ NMR $\left(500 \mathrm{MHz}, \mathrm{CDCl}_{3}\right.$, rt) spectrum of $\mathbf{3 b}$. 


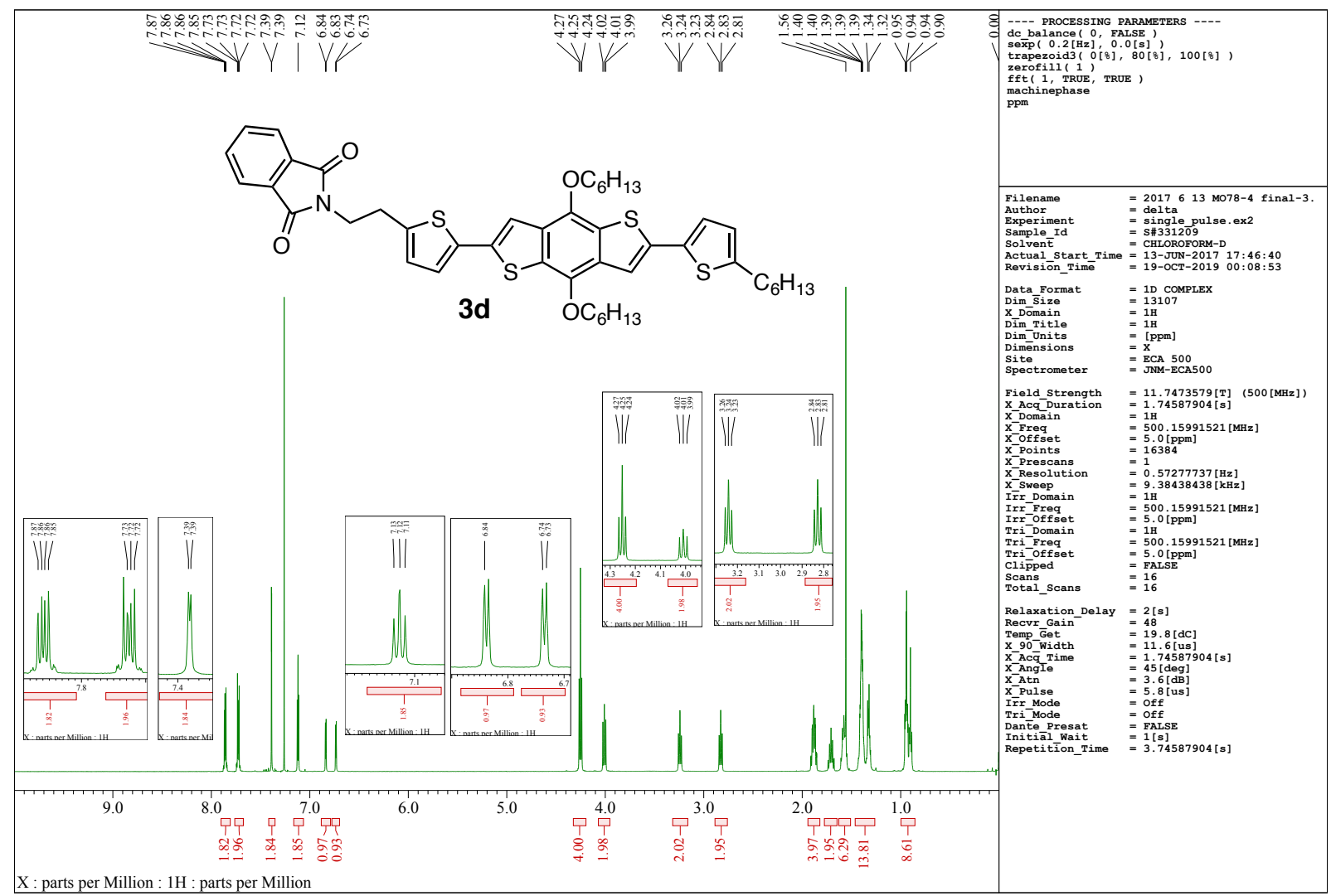

Figure S35. ${ }^{1} \mathrm{H} \mathrm{NMR}\left(500 \mathrm{MHz}, \mathrm{CDCl}_{3}\right.$, rt) spectrum of $\mathbf{3 d}$.

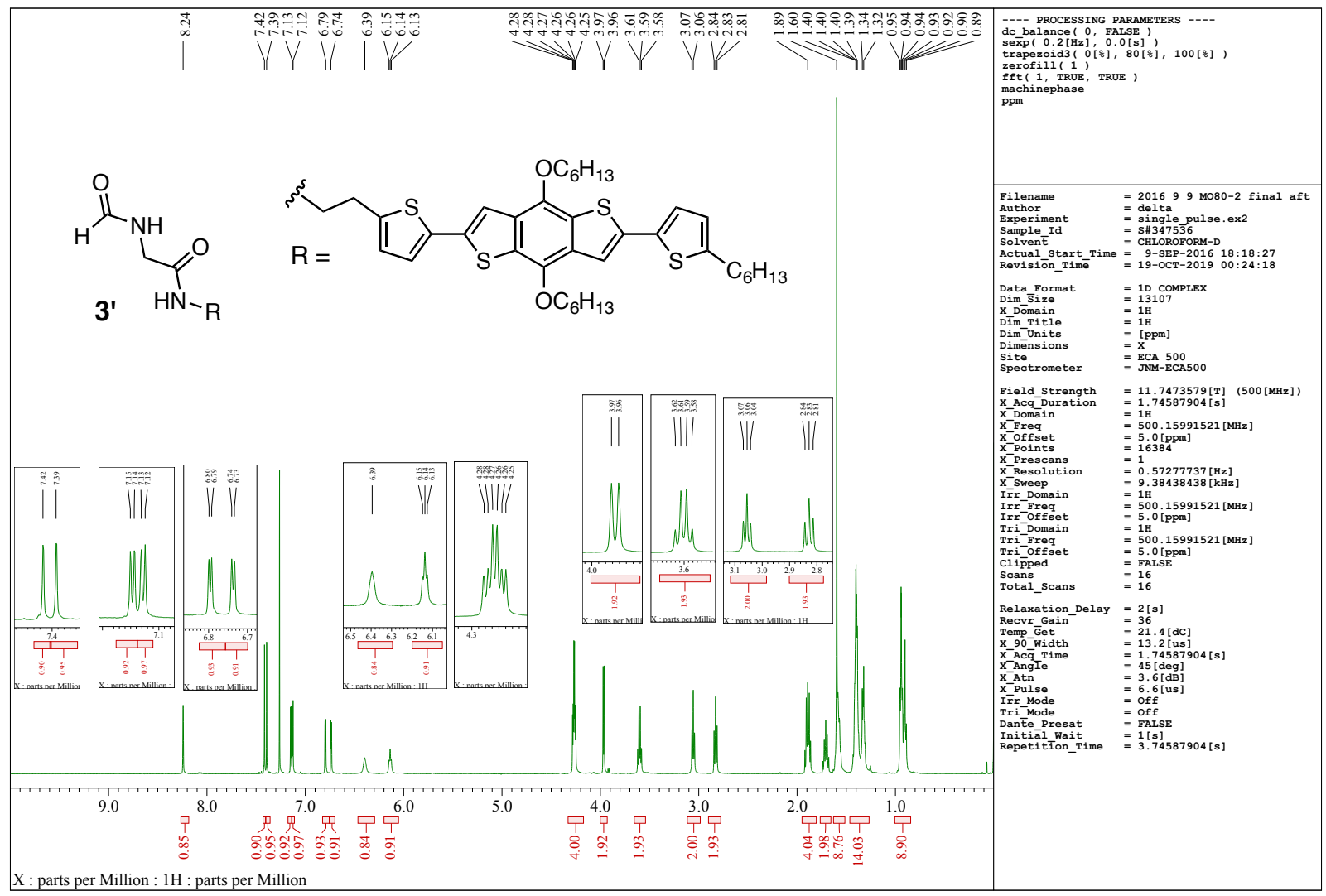

Figure S36. ' $\mathrm{H}$ NMR (500 MHz, $\mathrm{CDCl}_{3}$, rt) spectrum of 3'. 


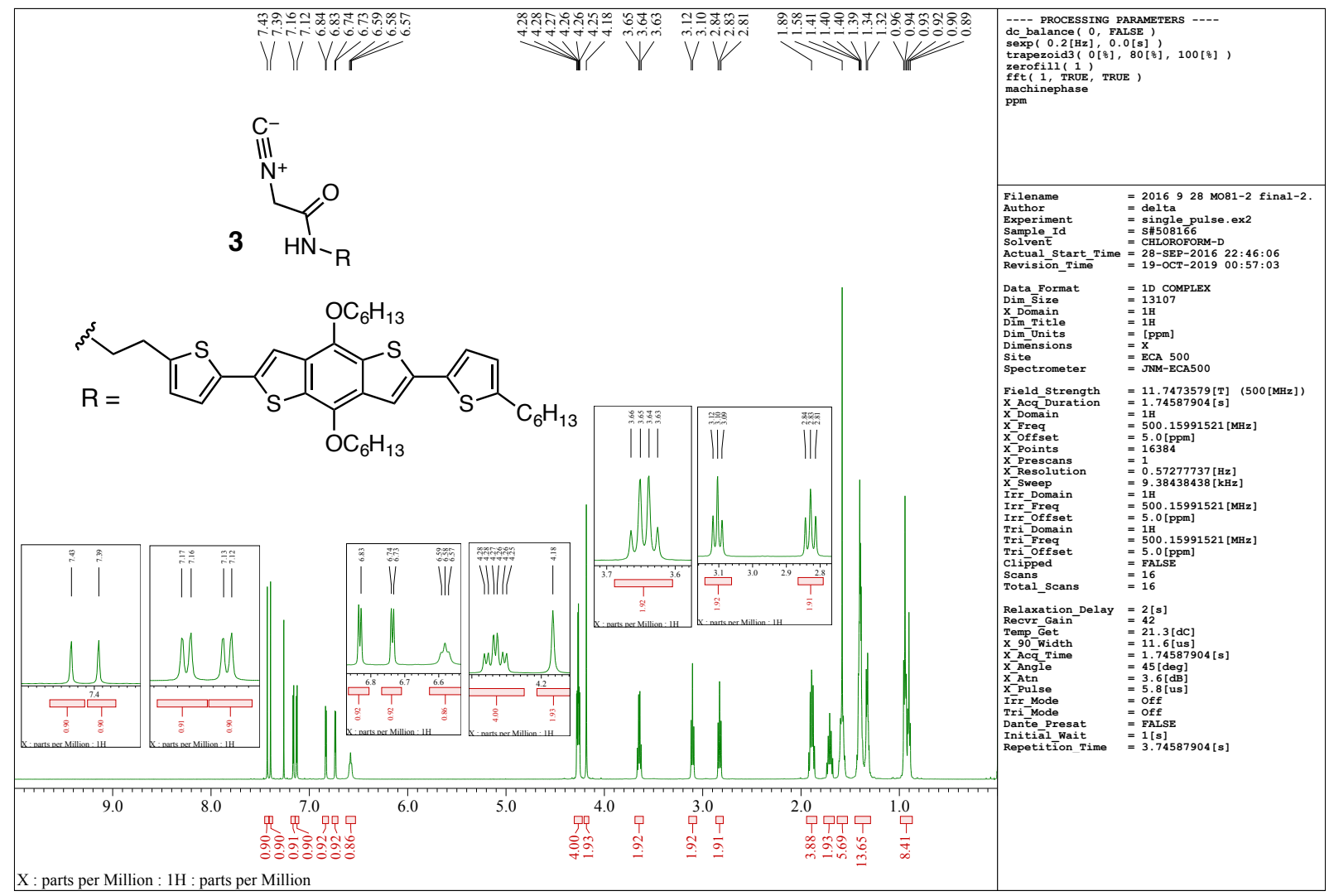

Figure S37. ${ }^{1} \mathrm{H}$ NMR $\left(500 \mathrm{MHz}, \mathrm{CDCl}_{3}\right.$, rt) spectrum of 3 .

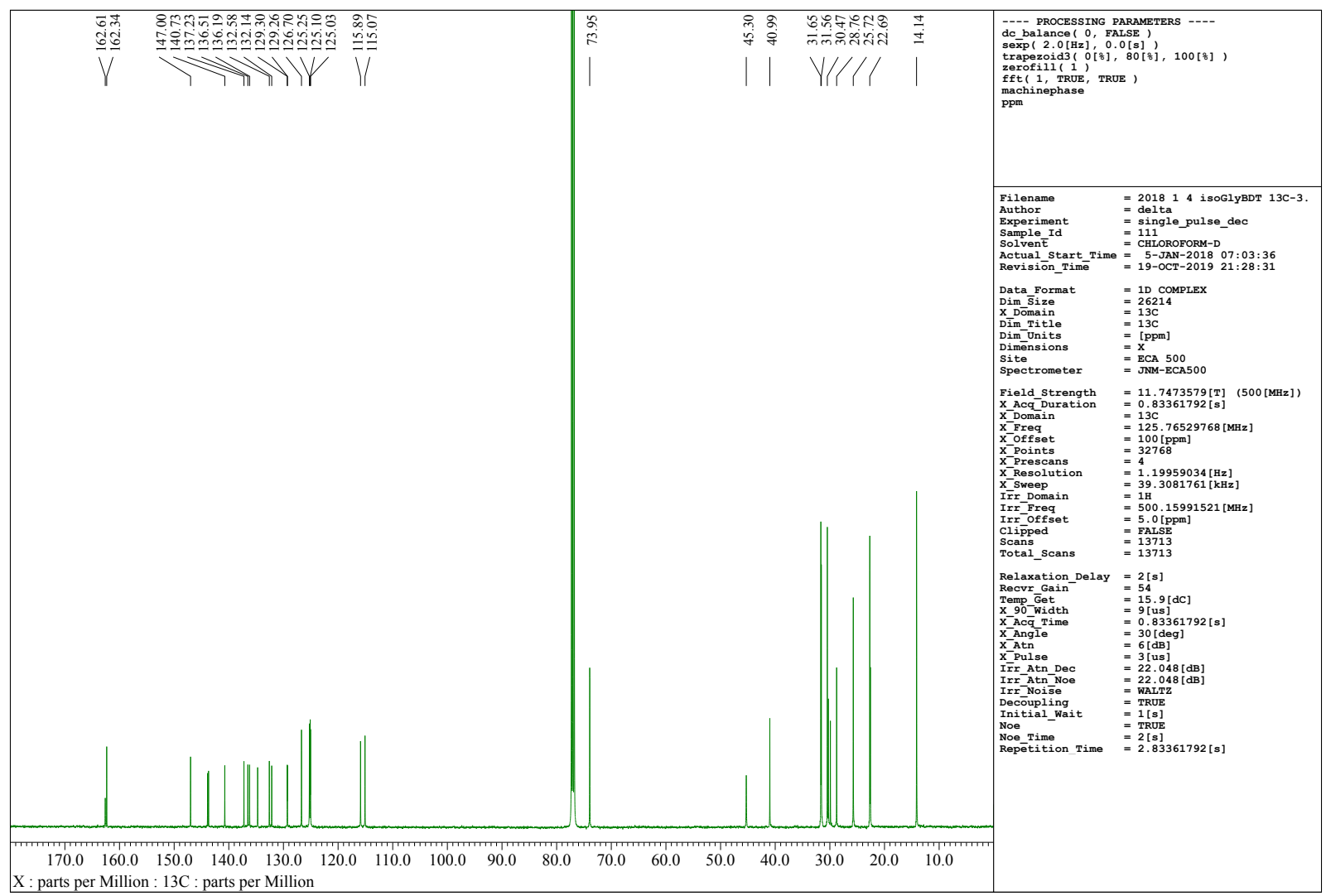

Figure S38. ${ }^{13} \mathrm{C}$ NMR (126 MHz, $\left.\mathrm{CDCl}_{3}, \mathrm{rt}\right)$ spectrum of 3 . 


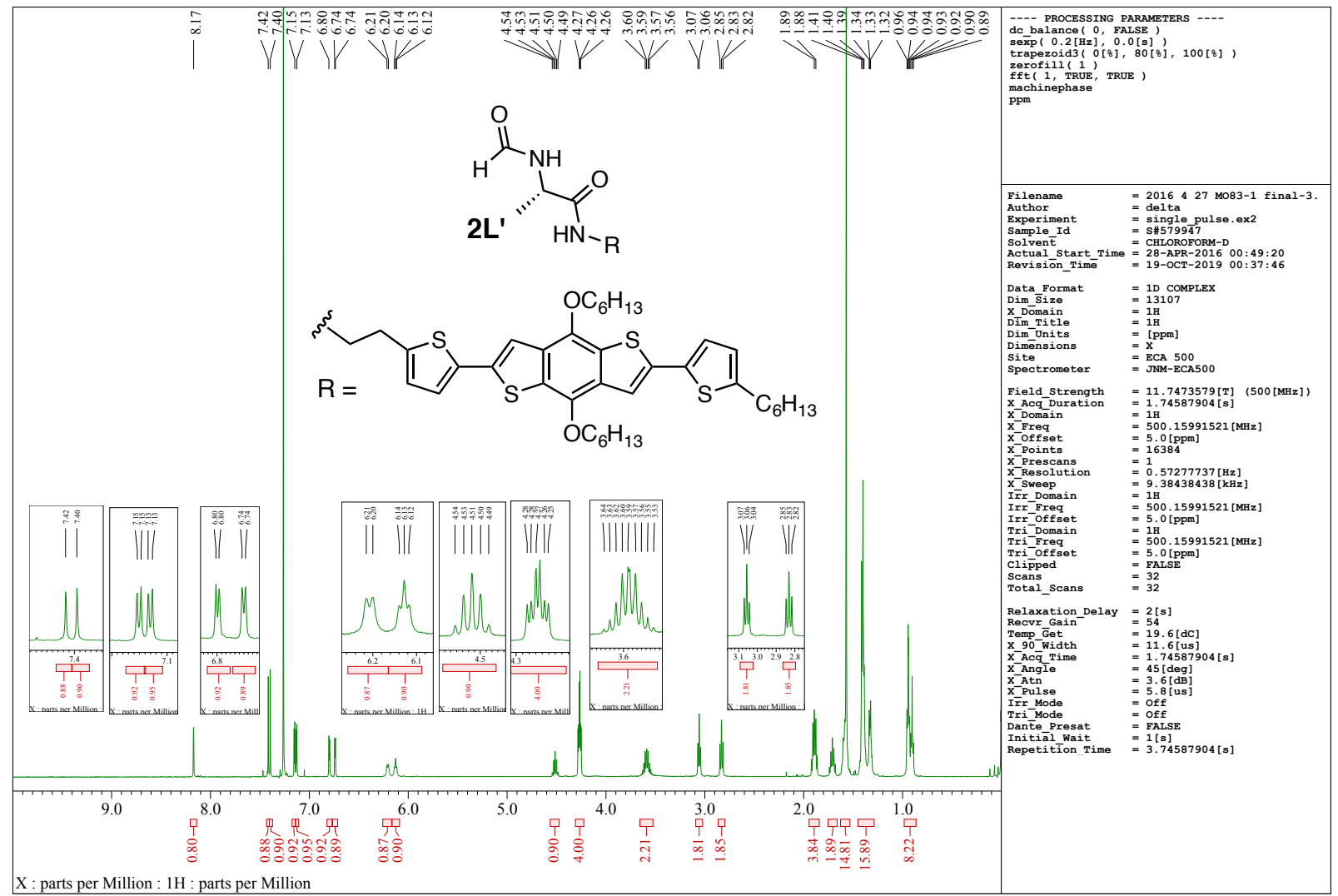

Figure S39. ${ }^{1} \mathrm{H}$ NMR (500 $\mathrm{MHz}, \mathrm{CDCl}_{3}$, rt) spectrum of $\mathbf{2 L}$ '.

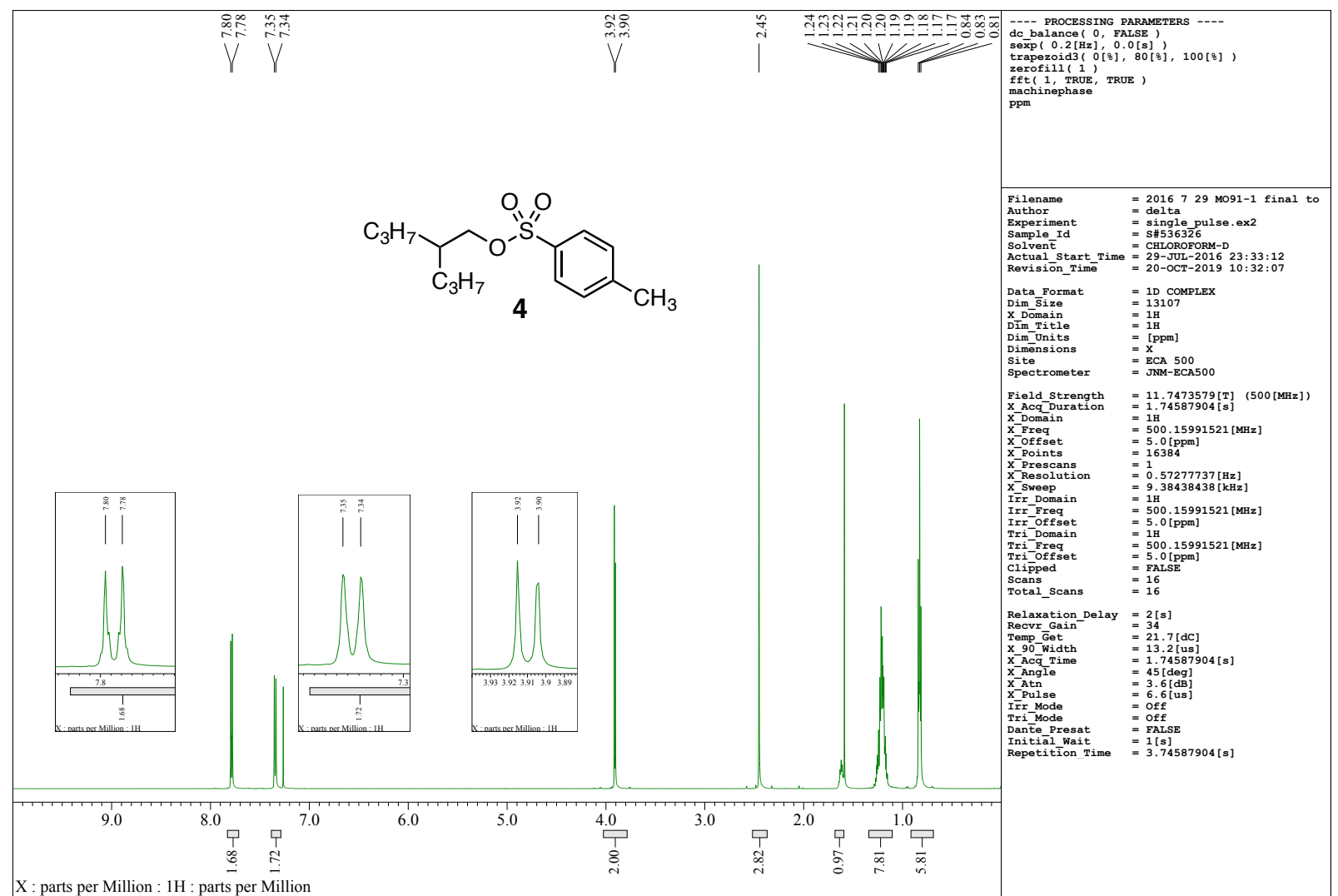

Figure S40. ${ }^{1} \mathrm{H}$ NMR $\left(500 \mathrm{MHz}, \mathrm{CDCl}_{3}, \mathrm{rt}\right)$ spectrum of 4. 


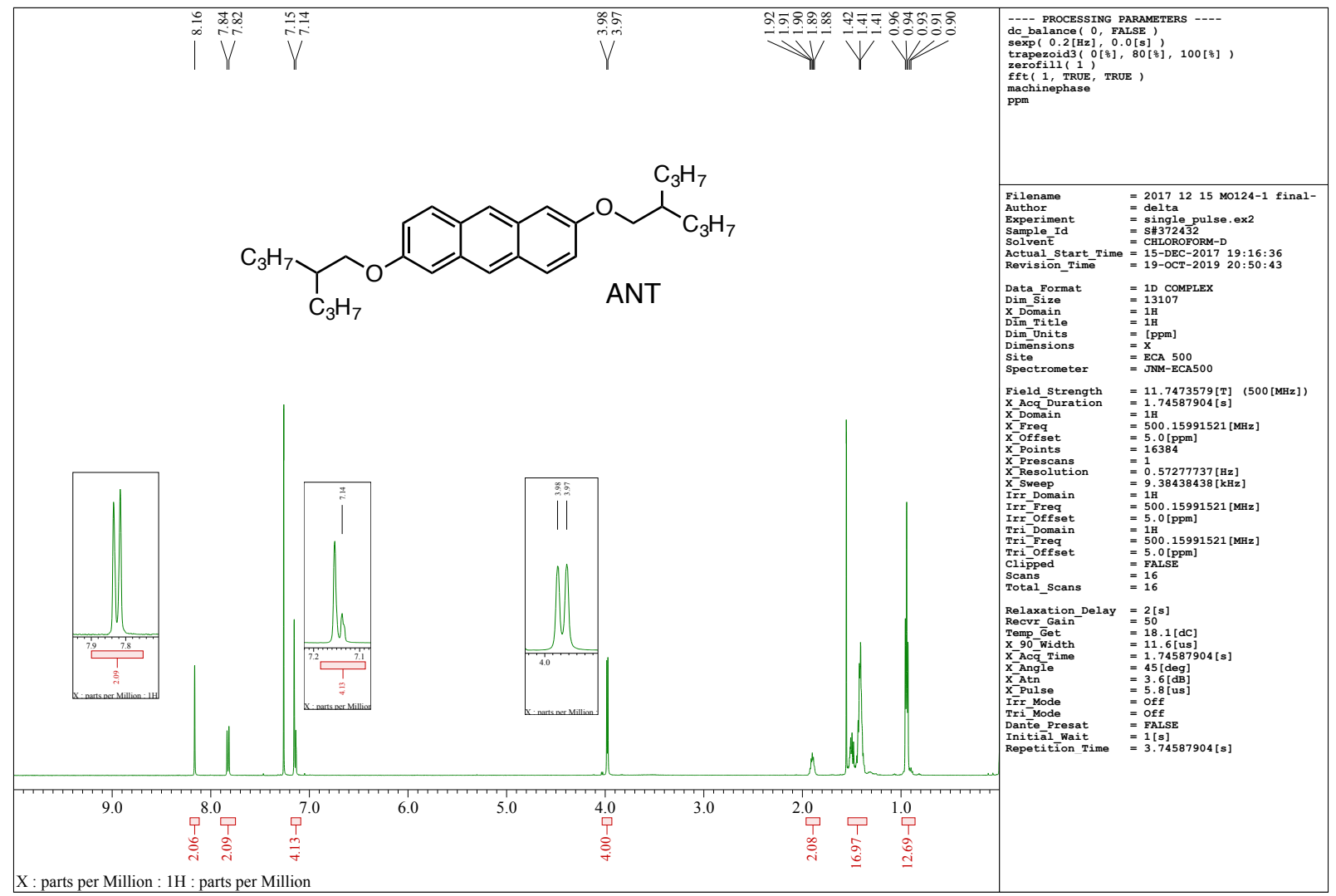

Figure S41. ${ }^{1} \mathrm{H}$ NMR $\left(500 \mathrm{MHz}, \mathrm{CDCl}_{3}\right.$, rt) spectrum of ANT.

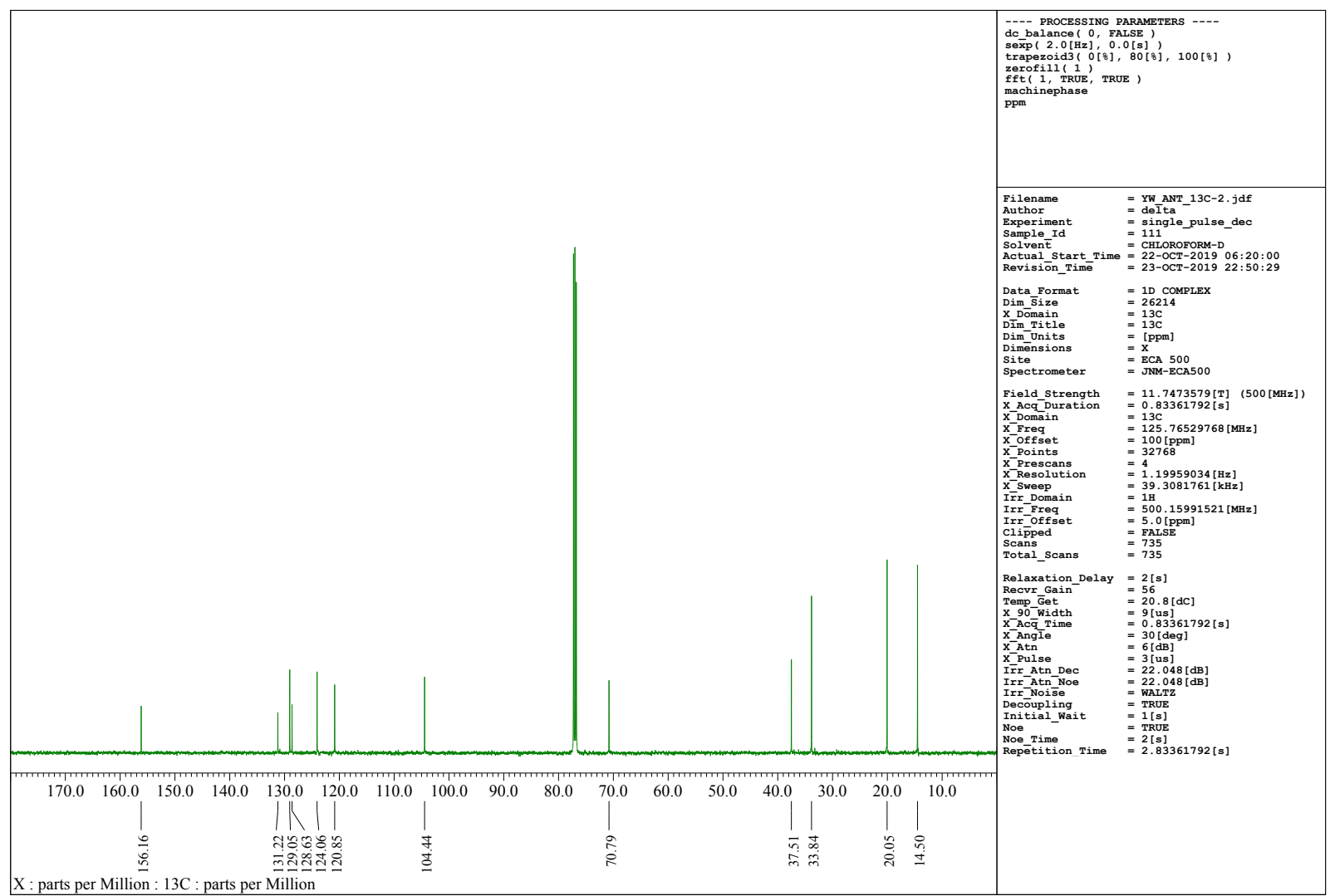

Figure S42. ${ }^{13} \mathrm{C}$ NMR $\left(126 \mathrm{MHz}, \mathrm{CDCl}_{3}\right.$, rt) spectrum of ANT. 


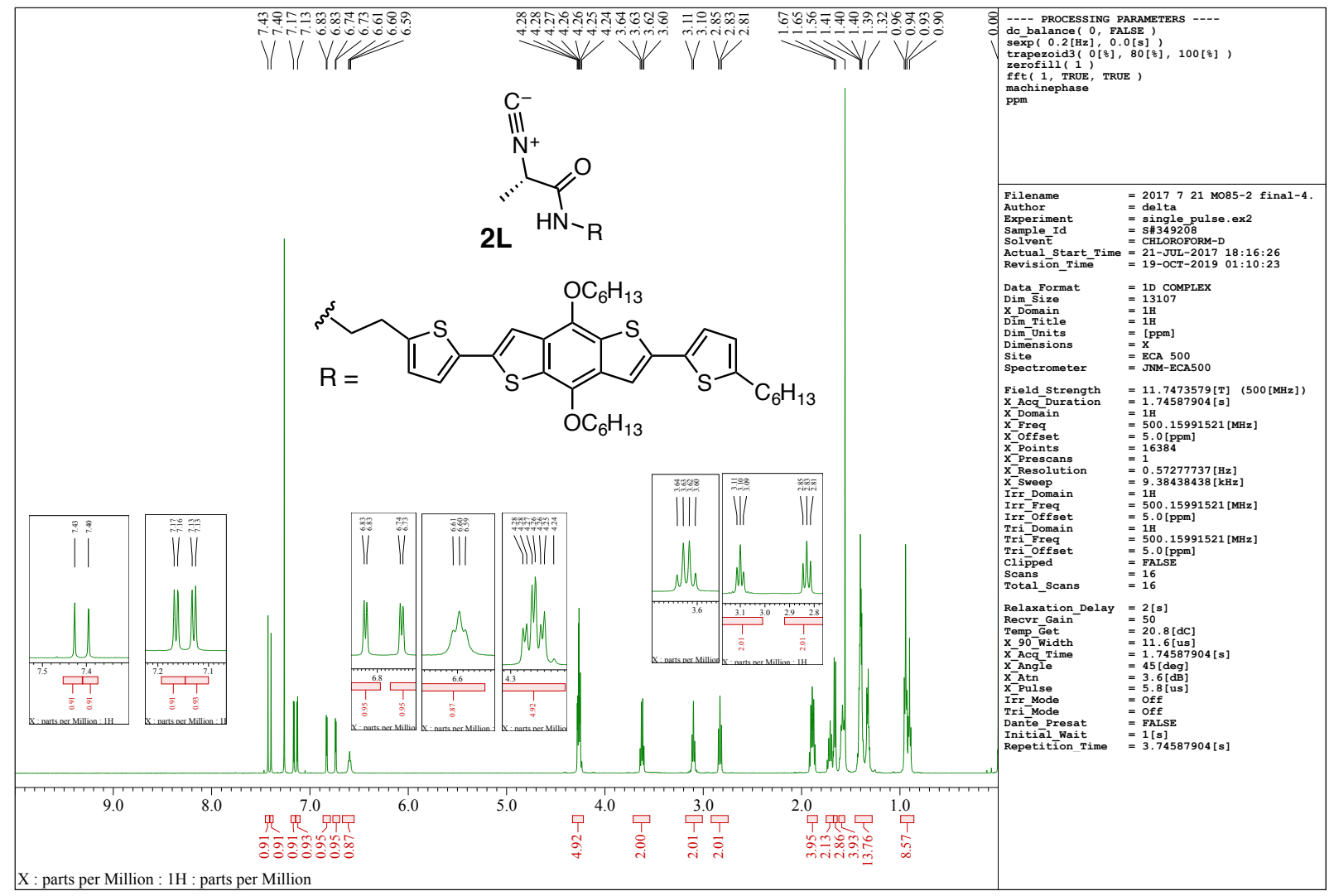

Figure S43. ${ }^{1} \mathrm{H} \mathrm{NMR}\left(500 \mathrm{MHz}, \mathrm{CDCl}_{3}\right.$, rt) spectrum of $\mathbf{2} \mathbf{L}$.

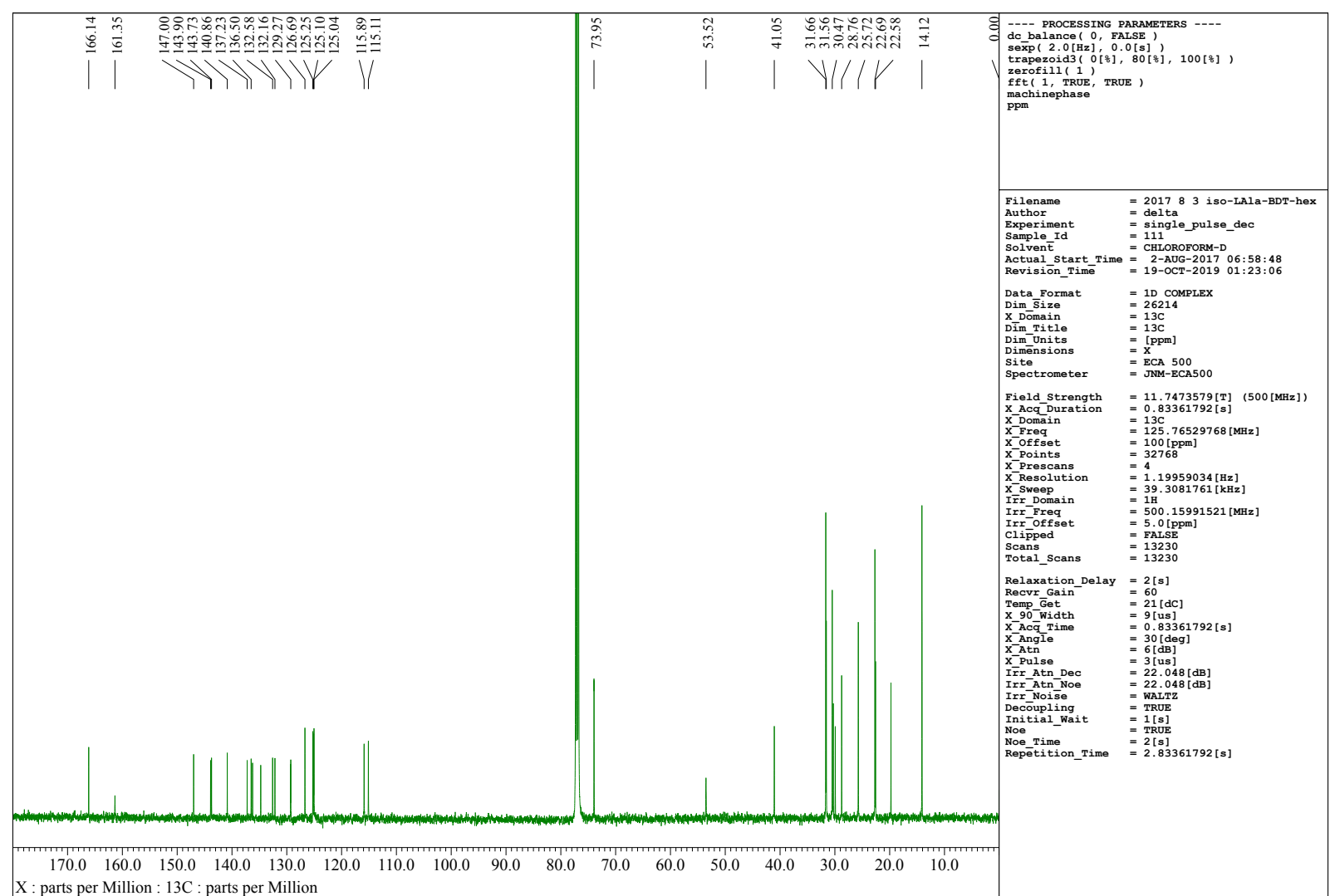

Figure S44. ${ }^{13} \mathrm{C}$ NMR $\left(126 \mathrm{MHz}, \mathrm{CDCl}_{3}, \mathrm{rt}\right)$ spectrum of $\mathbf{2} \mathbf{L}$. 


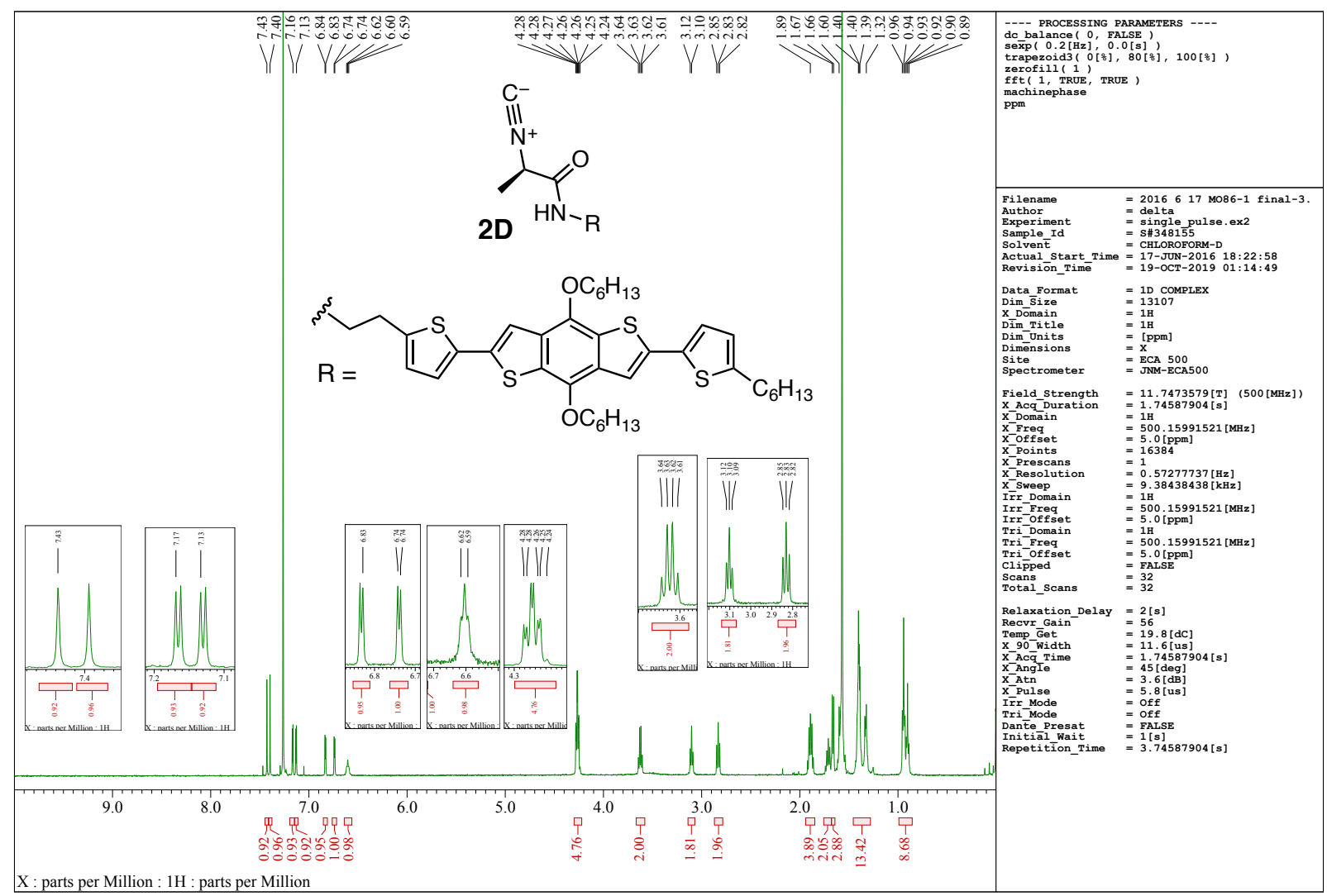

Figure S45. ${ }^{1} \mathrm{H}$ NMR $\left(500 \mathrm{MHz}, \mathrm{CDCl}_{3}\right.$, rt) spectrum of 2D.

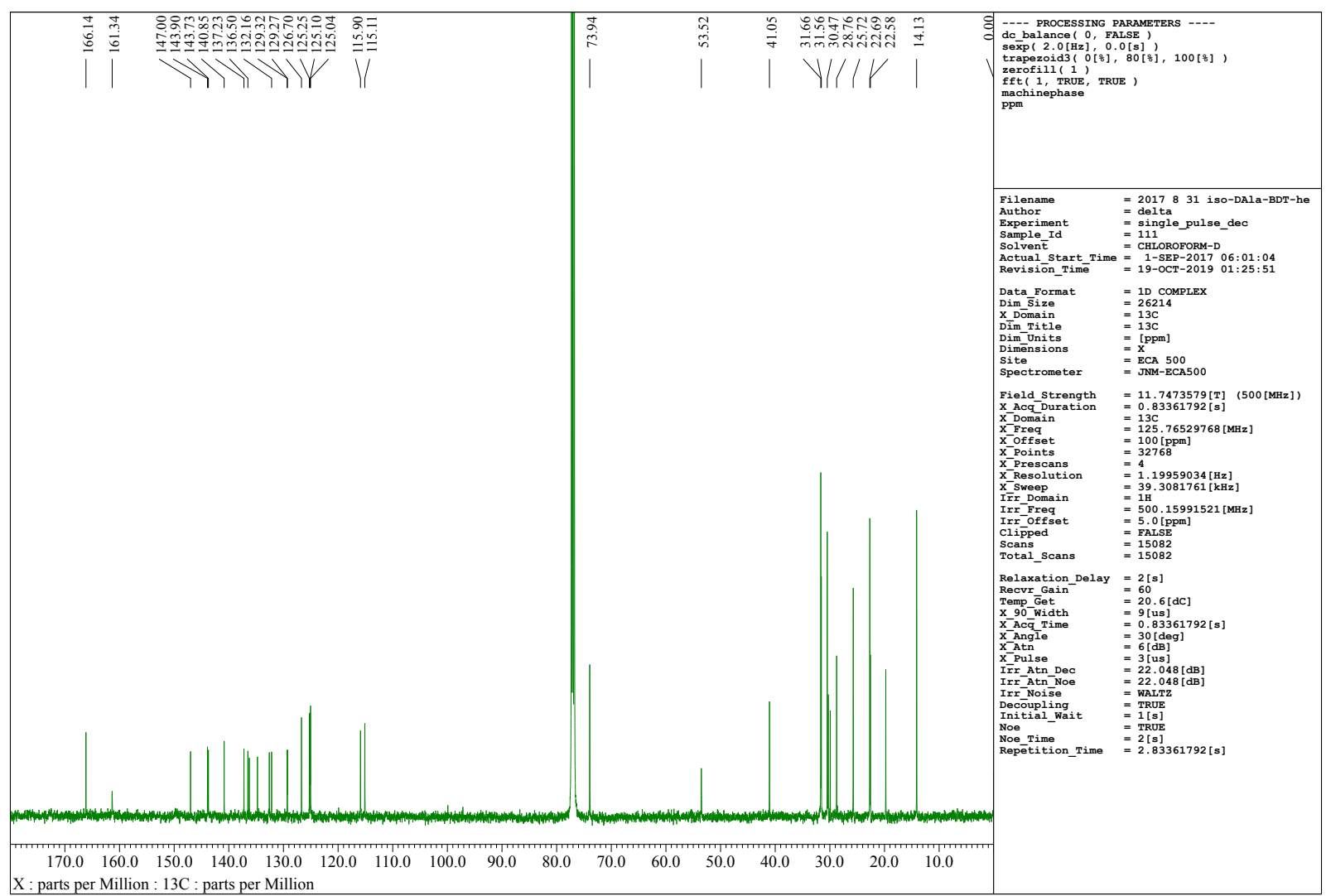

Figure S46. ${ }^{13} \mathrm{C}$ NMR $\left(126 \mathrm{MHz} \mathrm{CDCl}_{3}, \mathrm{rt}\right)$ spectrum of 2D. 


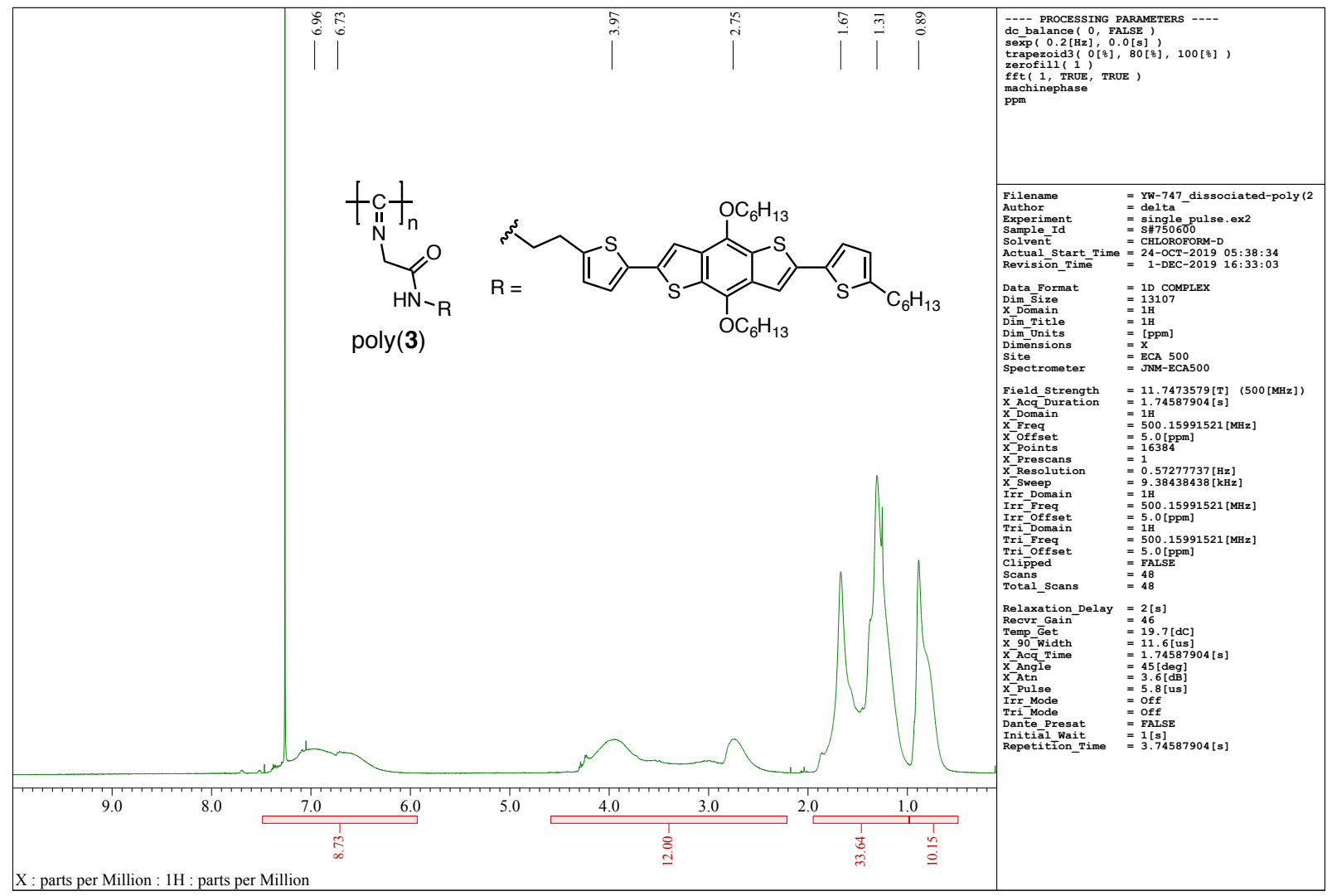

Figure S47. ${ }^{1} \mathrm{H}$ NMR $\left(500 \mathrm{MHz}, \mathrm{CDCl}_{3}\right.$, rt) spectrum of the completely dissociated poly(3). 


\section{References}

(S1) Aeschi, Y.; Li, H.; Cao, Z.; Chen, S.; Amacher, A.; Bieri, N.; Özen, B.; Hauser, J.; Decurtins, S.; Tan, S.; Liu, S.-X. Directed Metalation Cascade To Access Highly Functionalized Thieno[2,3-f] benzofuran and Exploration as Building Blocks for Organic Electronics. Org. Lett. 2013, 15, 5586-5589.

(S2) Tian, N.; Thiessen, A.; Schiewek, R.; Schmitz, O. J.; Hertel, D.; Meerholz, K.; Holder, E. Efficient

Synthesis of Carbazolyl- and Thienyl-Substituted $\beta$-Diketonates and Properties of Their Red- and Green-Light-Emitting Ir(III) Complexes. J. Org. Chem. 2009, 74, 2718-2725.

(S3) Ikai, T.; Takagi, Y.; Shinohara, K.; Maeda, K.; Kanoh, S. Synthesis of Polyisocyanides Bearing Oligothiophene Pendants: Higher-Order Structural Control through Pendant Framework Design. Polym. J. 2015, 47, 625-630.

(S4) Wang, Y.; Zhang, I.; Yu, B.; Fang, X.; Su, X.; Zhang, Y.-M.; Zhang, T.; Yang, B.; Li, M.; Zhang, S. X.-A. Full-Color Tunable Mechanofluorochromism and Excitation-Dependent Emissions of Single-Arm Extended Tetraphenylethylenes. J. Mater. Chem. C 2015, 3, 12328-12334.

(S5) Matsui, M.; Ando, S.; Fukushima, M.; Shibata, T.; Kubota, Y.; Funabiki, K. Fluorescence Properties of Indolenium Carbocyanine Dyes in Solid State. Tetrahedron 2015, 71, 3528-3534.

(S6) Wada, Y.; Shinohara, K.; Asakawa, H.; Matsui, S.; Taima, T.; Ikai, T. One-Step Synthesis of One-Dimensional Supramolecular Assemblies Composed of Helical Macromolecular Building Blocks. J. Am. Chem. Soc. 2019, 141, 13995-14002.

(S7) Considering the structural and chiroptical stability of the supramolecular systems as described below, the polymerizations were performed at $-10{ }^{\circ} \mathrm{C}$ in this study, instead of $20{ }^{\circ} \mathrm{C}$ adopted in the previous report, unless otherwise noted. 